Portland State University

PDXScholar

2-28-1995

\title{
Motion Picture Exhibition and the Development of a Middle-class Clientele: Portland, Oregon, 1894-1915
}

James Bruce Labosier

Portland State University

Follow this and additional works at: https://pdxscholar.library.pdx.edu/open_access_etds

Part of the History Commons

Let us know how access to this document benefits you.

\section{Recommended Citation}

Labosier, James Bruce, "Motion Picture Exhibition and the Development of a Middle-class Clientele: Portland, Oregon, 1894-1915" (1995). Dissertations and Theses. Paper 4952.

https://doi.org/10.15760/etd.6828

This Thesis is brought to you for free and open access. It has been accepted for inclusion in Dissertations and Theses by an authorized administrator of PDXScholar. Please contact us if we can make this document more accessible: pdxscholar@pdx.edu. 
THESIS APPROVAL

The abstract and thesis of James Bruce Labosier for the Master of Arts in History were presented February 28, 1995, and accepted by the thesis committee and the department.

COMMITTEE APPROVALS :

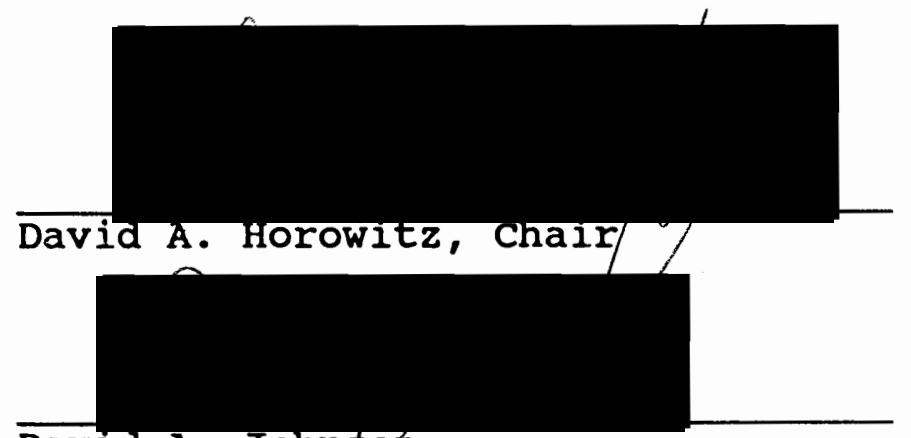

David A. Johnsoh

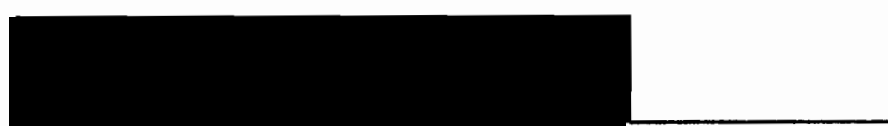

Franklin C. West

DEPARTMENT APPROVAL:

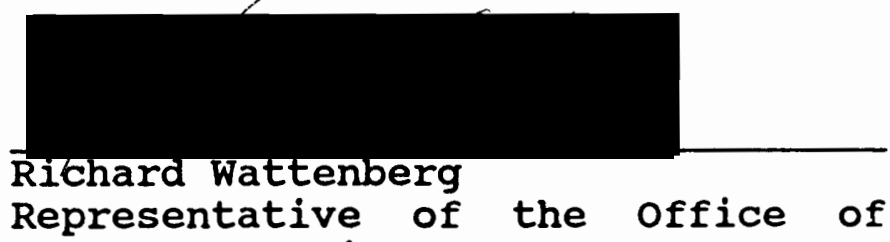
Graduate studies

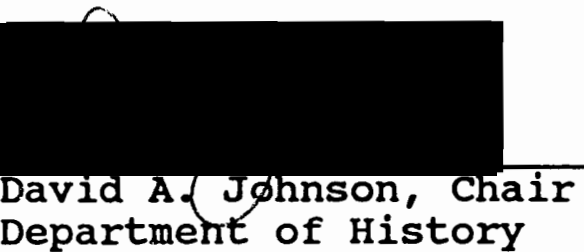

Department of History

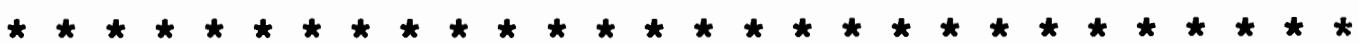

ACCEPTED FOR PORTLAND STATE UNIVERSITY BY THE LIBRARY

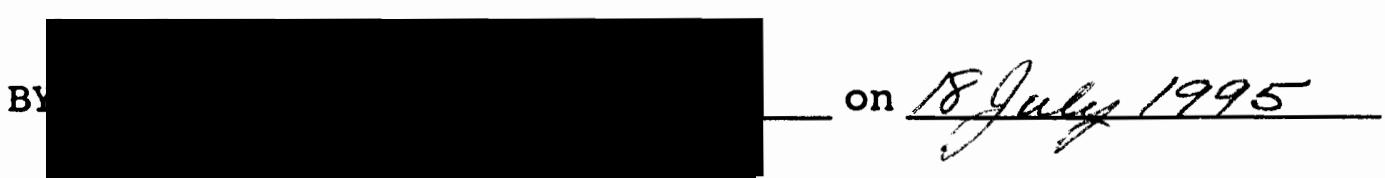




\section{ABSTRACT}

An abstract of the thesis of James Bruce Labosier for the Master of Arts in History presented February 28, 1995.

Title: Motion Picture Exhibition and the Development of a Middle-Class Clientele: Portland, Oregon, 18941915 .

For about the first fifteen years after its commercial introduction motion picture entertainment throughout the United states was supported almost entirely by the mass of urban industrial workers, immigrants and their families. Beginning a few years before 1910 motion pictures began acquiring regular support from a limited element of the more affluent citizens until by the end of 1916 they constituted motion pictures' primary audience. This paper examines the audience development and conversion as it occurred in the downtown theaters of Portland, Oregon.

Motion pictures were shown to two diverse audiences in Portland during the 1890s, regularly on a mass level to the lower income strata and sporadically to regular stage theater audiences. Their expectations differed greatly. Urban workers craved entertainment for the sake of diversion while middle and upper class audiences required 
responsibility and purpose in their entertainments. After the turn of the century when big time vaudeville established itself in Portland films were supported almost entirely by the lower class element in arcades and vaudeville theaters. Motion pictures in these venues catered to their audiences' tastes.

During the 4-5 year period after nickelodeons developed in 1906 a small number of Portland's middle class became regular patrons, due partially to national imposition of licensing and establishment of a censorship board fostering a more respectable image.

After 1910, when national support for motion pictures had been proven permanent and unsatisfied, large movie palaces emerged in Portland. These theaters and their amenities created atmospheres consistent with those of stage theaters, providing comfortable and familiar surroundings for middle class audiences. Industrywide developments such as increased story length, better quality productions and evidence of social responsibility enhanced the ease of middle class transition from the stage theater to the movie theater. 
MOTION PICTURE EXHIBITION AND THE DEVELOPMENT OF A MIDDLE-CLASS CLIENTELE:

PORTLAND， OREGON， 1894-1915

by

JAMES BRUCE LABOSIER

A thesis submitted in partial fulfillment of the requirements for the degree of

MASTER OF ARTS

in

HISTORY

Portland State University

1995 


\section{TABLE OF CONTENTS}

\section{PREFACE}

CHAPTER

PAGE

I THE ORIGINS OF NEW AMUSEMENTS: EARLY MOTION PICTURES AND VAUDEVILLE, 1894-1906. •. . . . . . . . . . 1

II THE NICKELODEON AND THE ERA OF TRANSITION, 1906-1910 •. . . . . . 30

III MARKETING INNOVATION AND THE CAMPAIGN FOR EXPANDED PATRONAGE, 1910-1915. •. .48

IV CREATION OF UNIQUE AND APPEALING MOVIE ENVIRONMENTS, 1910-1915. . . . . . . 74

CONCLUSION • • • • • • • • • • • • • • • • • • . 98

APPENDIX • . . . . . . . . . . . . . . . . 102 


\section{CHAPTER I}

THE ORIGINS OF NEW AMUSEMENTS: EARLY MOTION PICTURES AND VAUDEVILLE, 1894-1906

Portland was the Pacific Northwest's largest city in the 1890s. Although it had been founded less than fifty years earlier its population in 1892 was second only to san Francisco's on the West Coast. After consolidation with East Portland and Albina in 1892, its population doubled to approximately one hundred thousand by the turn of the century. Residential growth was attracted by a booming economy which, excepting the depression of 1892-3, continued from the late $1880 \mathrm{~s}$ through the decade. Transportation businesses, especially railroad, and manufacturing, attracted much of Portland's expansion. Banking, real estate, street railways, and various industrial investment constituted other leading economic forces. Most enterprises were controlled by merchant families whose roots extended back to Portland's initial growth in the 1840 s and 1850s. By the turn of the twentieth century, these predominantly Anglo-Protestant families and business leaders comprised the city's social and cultural elite.'

Portland's establishment dominated city politics in an 
era in which an unobtrusive municipal government subordinated itself to predominant business interests. Consequently, city administration suffered throughout the 1890s, a period characterized by a chronically anemic tax base. Lack of support for the police department also contributed to widespread corruption intensified by the fact that much of the city's elite profited from thriving vices. ${ }^{2}$

By the start of the twentieth century, Portland's fundamental character was changing. Its unprecedented industrial expansion encouraged large and diverse groups of emigrants. The needs of a mass urban laboring population conflicted with a domain characterized by municipal neglect and inadequacy. The industrialized work force, moreover, was increasingly divided from a victorian elite which offered no relevant leadership and often did not share their cultural or ethnic background. ${ }^{3}$

As the city grew, Portland's elite continued to isolate itself from poorer immigrant populations. It followed examples of East Coast elite society, establishing exclusive social clubs, epitomized by the Arlington Club, and coalescing around Protestant congregation affiliations. When Portland became crowded, the leading families moved away from inner city population centers. Many of the immigrants before the 1880s included blacks, Chinese, and Irish who often resided in East Portland or in segregated areas on the 
West Side. By the 1890s Jews, first German and later Eastern European, Italians, Japanese, and Scandinavian families were arriving. Local industrial growth provided work for most as laborers. With their own cultural traditions and lifestyles defined by industrial work habits, the poorer immigrants had different needs than the established elite. Entertainment illustrated the gulf. While the upper class promenaded at large, segregated stage theaters, working families found diversion through amusement in saloons and at cheap vaudeville shows. ${ }^{4}$

Between 1894 and 1906 Portland developed two distinct motion picture audiences. Middle and upper class theatergoers witnessed projected motion pictures until the turn of the century. Immigrant and laboring classes patronized peep show machines until regular vaudeville provided screened films. The filmmaking industry catered to two different entertainment expectations. Stage theaters produced shows supporting Victorian social values. Films shown at these locations required redeeming social value. However, growing industrial and immigrant populations sought undemanding release from lives of poverty and overwork. Vaudeville and boxing subjects attracted them to peep show machines in saloons, restaurants, and arcades before theaters offered similar fare on screen.

Late in 1894 , the Kinetoscope arrived in Portland. The first motion picture device marketed in America, it was 
developed at Thomas Edison's New Jersey laboratories. The Kinetoscope displayed photographs through a peep-show device holding about one minute's worth of entertainment on an inch wide film. It had been marketed for less than a year by Norman Raff and Frank Gammon, who obtained Edison's permission to form a company in August 1894 which sold commercial exhibition rights and films for the device. In November 1894 , Kinetoscopes were first offered in Portland without fanfare, although the city was only the second West Coast location in which they were available. ${ }^{5}$

The Kinetoscope's subject matter and viewing limitations precluded its presence in Portland's elite stage theaters. Upon developing a marketing strategy for the Kinetoscope, Edison and Raff \& Gammon aimed for a lower class audience. While Edison still envisioned motion pictures as a great education device, he conceded that vaudeville topics were appropriate for an audience with specific entertainment requirements. The Kinetoscope fit the leisure demands of urban immigrants and wage-earners. It provided a brief, inexpensive, and informally attended affair that did not limit audiences by language and provided entertainment without Victorian morals or lessons. Kinetoscopes most frequently occupied saloons and restaurants as diversionary attractions, although these places were usually located in the downtown business district near the stage theaters. 
A restaurant in the Knickerbocker Block building on Washington Street, a Kinetoscope source in June 1896, typified Portland's peep show locations in the 1890s. The major legitimate theaters, Cordray's Theatre and the Marquam Grand, populated this area. They coexisted with concert halls, most notably the Fredericksburg, saloons offering live performances of varied legitimacy. Geographically, the Kinetoscope was available to Portland's high and low brow amusement seekers, but it was ignored in local newspaper theatrical pages. ${ }^{6}$

American and European competition to develop projection technology culminated in the debut of the Lumiere brothers Cinematographe projector at Lyons, France in March 1895. Peep show motion picture entertainment facilitated an initial period of national popularity before levelling off during 1896. Machines based on the Kinetoscope and the post1896 rival Mutoscope formats remained common in saloons and arcades for much of the next fifteen years, doomed by their design to sideshow status. Peep show machines accommodated only one spectator at a time while promoters, urban population growth, and an industrial business ethic demanded mass production and consumption satisfied only by attracting mass audiences to motion pictures projected on a screen. After failing to develop a successful projector in his own laboratories, Thomas Edison bought copyrights from Thomas Armat and C. Francis Jenkins and introduced the Vitascope 
projector to New York City audiences in April 1896.'

Motion picture projection created a potential mass audience but faced supply limitations and lacked regular theatrical outlets. Unlike peep show machines, projectors required locations with large seating and viewing capabilities such as music halls and stage theaters. In Portland, projected motion pictures usually were shown in large stage theaters at regular theater prices. The entertainment conceptions of these audiences were different from the leisure demands of urban immigrants and working class people. While undereducated and overworked patrons sought cheap diversion of any sort, middle and upper class audiences expected literate and morally instructive productions. ${ }^{8}$

Projected motion pictures debuted at Cordray's Third street theater as a scientific curiosity. John Cordray arranged through I. Leeser Cohen, a local merchant, to introduce Edison's Vitascope in December 1896. Films split the bill with live performances by Professor Zera's variety troupe. Audiences paid Cordray's regular prices, ranging from 25 cents to $\$ 1.50$, to see the show but did not really regard the films as entertainment as Kinetoscope audiences did. Cordray's audience was primarily attracted to the Vitascope as an invention, a scientific advancement, and considered the show an exhibition more than entertainment. The oregonian reported that many in the audience were 
interested in the future technical possibilities of such devices. Children were encouraged to attend showings for their educational value. Contemporary newspaper accounts reveal that while the comic scenes were appreciated for their humor, most interest centered on a scene of ocean waves crashing on a rocky jetty. This was considered an excellent example of the potential of motion pictures to replicate nature. 9

The concept of film as pure entertainment or vicarious release almost entirely escaped Cordray's viewers. According to the oregonian, one scene of a dancing girl, appreciated on its photographic merits, elicited confused reactions when hand-painted sections of film made the girl's dress seem to change color. Slight indignation and embarrassment ensued when the famous May Irwin-John Rice film of 'The Kiss' was shown; one reviewer said its close-up depiction of a man kissing a woman was "risque", while another said "a little of it goes a long ways." Despite their slight misgivings, Cordray's audiences responded positively to the debut of film among the Portland upper class and the exhibition was held over a week beyond its scheduled seven-day run. ${ }^{10}$ Portland's subsequent screenings implicitly justified themselves through technological refinements. Scenic and newsworthy topics comprised these shows. In August 1897 motion pictures played twice, once in the idle Heilig theater, and once in the Armory. National competition in the 
film projector market increased greatly after 1896, with many foreign and domestic companies creating their own devices. One of these, the Veriscope, projected film of the actual heavyweight prize fight between James Corbett and Robert Fitzsimmons at Carson City, Nevada in March 1897. Although boxing was traditionally considered a vulgar sport only worthy of the lower classes, the film of the match was shown at the Heilig for three days in August 1897 for prices ranging from 50 cents to $\$ 5.00$. Theater audiences saw documented motion picture evidence of a widely publicized historical event, an attraction as significant as the interest in boxing. The Corbett-Fitzsimmons film also demonstrated a problem identified by audiences. While projection devices still were being perfected, technical difficulties often caused shaky and blurred pictures, creating a widespread belief that watching projected films resulted in eye damage. ${ }^{11}$

During the same month as the Heilig showing, Dr. Gregory De Kannet's Electrograph projected film at the Portland Armory on six separate occasions. The series of films was part of a concert promenade program sponsored by the Oregon National Guard, comprised wholly of scenic and news features. Topics including President William McKinley's inauguration, various scenes of New York City, and local footage of the willamette River and an Oregon railroad train. Although the presentation did not occur in a regular 
theater, prices of 25 cents and 50 cents for general seating were only slightly lower than stage prices. The primary concession was free admittance for children. Electrograph's claims of improved screening ability attracted the technologically aware, although the show also experienced problems with focusing. ${ }^{12}$

Continuing the established pattern of introducing new projecting devices to theater audiences by depicting current events, three different presentations of Spanish-American War topics took place in Portland in 1898. Edison's Triograph played along with a live theater company at Cordray's theater in April 1898. With no change in its regular prices, Cordray's ran features dealing with Cuba, Washington, and the recently ignited Spanish-American War. Just one month later, the Marquam Grand offered Lumiere on the Kinematographe of the battleship Maine in Havana Harbor. In July, when the war had played itself out, a temporary venue began to show films of various war topics, including footage of an Oregon contingent leaving port in San Francisco for duty in the Philippines. The Viclorama Parlors rented space for less than a month in the Cyclery Building on downtown's Sixth Street. Each showing offered audiences motion pictures projected through devices never before used in Portland. Indeed, technological refinement continued to remain as great an impetus for the exhibition of motion pictures as the subjects themselves. Film projections 
continued to be accessible in price, ranging from twenty five cents to a dollar. ${ }^{13}$

The last Portland exhibition that appealed to the technological bent of affluent audiences took place at the Marquam Grand in March 1900. The American Biograph and Mutoscope Company had developed a projector and camera accommodating larger film capable of holding and projecting clearer images. The Marquam Grand now used the Biograph projector to show a two and a half hour film of the Jeffries-Sharkey heavyweight title boxing match. Meanwhile, the YMCA presented movies for two nights. Although concentrating on religion and news, promoters made no mention of the projection device and delivered no claims of superiority or refinement. Prices remained in the customary range of twenty five to fifty cents. Nevertheless, motion picture projection in Portland still rested with the middle and upper classes. ${ }^{14}$

In the eight years following 1894, peep show machines were the only regular motion picture viewing outlet in Portland. Yet the situation changed dramatically with the introduction of vaudeville in 1902. Tied to ever larger and prestigious circuits and based on East Coast formats, vaudeville appealed to predominantly working and lower class audiences. Standard vaudeville programs featured an illustrated song and bills of six thematically varied acts lasting about ten minutes each. Singers interpreted popular 
music to the accompaniment of projected photographic slides. Each program had two or three scheduled starting times daily. Admission was typically ten cents, sometimes twentyfive cents for box seats. Hour-long vaudeville programs ran without intermissions and without showtimes for the particular acts on the bill.

Vaudeville was an outgrowth of earlier nineteenth century saloon entertainment featuring off-color themes. During the 1880s, Tony Pastor and B. F. Keith developed sanitized versions of this entertainment on the East coast by removing it from the saloon and upgrading the acts. By appealing to families, particularly to women and children, vaudeville offered a much larger audience than saloons. Family acceptability and inexpensive admissions allowed vaudeville to become a hugely successful theatrical institution by the turn of the century. Motion pictures, in turn, became regular features of New York City's major vaudeville bills by $1897 .^{15}$

Portland's family vaudeville theaters followed the successful guidelines of the East. They actively promoted themselves as clean and family-oriented with special accommodations and comfortable ventilation to enhance their desirability. The city's family vaudeville theaters emphasized their separation from saloons and the racial segregation of audiences, specifically excluding Chinese and restricting black patrons. Adoption of East Coast vaudeville 
methods were used as selling points to reinforce the connection between Portland's shows and the most renowned national vaudeville circuits. Portland's Edward T. Shields first combined film with vaudeville, on a weekly basis for a summer run beginning in June 1902. The promoter presented vaudeville in Shields Park, an open air theater constructed at downtown's 13 th \& Washington. Due to personal relations with the Selig company, Shields showed the company's films exclusively ${ }^{16}$

Shields's successful introduction of family vaudeville in Portland inspired two other such theaters in 1903. Veteran local theater manager George L. Baker opened the Empire theater at 12 th street and Morrison in June. Although Baker's venture failed before the year was out, shields involved himself in the establishment of the Arcade Theater, which opened for vaudeville that October. Within a week, however, shields abandoned his partnership with building owner S. Morton Cohn, who assumed active management of the enterprise and successfully presented vaudeville into May 1905.17

Although it did nothing to alter the basic audience composition, increasing vaudeville popularity expanded the number of regular viewing locations for motion pictures. Fred T. Merrill's Bijou Theater opened on Sixth street in April 1904. Shortly after the Bijou opened, Lawrence Keating and Daniel Flood inaugurated the Lyric theater at the corner 
of Seventh Street and Alder. S. Morton Cohn further contributed to the plurality of vaudeville venues by complementing his successful Arcade with the newly built Star theater on Washington Street. ${ }^{18}$

Entrepreneurs John Considine and Timothy Sullivan added to the city vaudeville mix by opening the Grand Theater in November 1906. Considine was an established theater magnate from Seattle who struck a partnership with New York political boss Sullivan. With Sullivan's wealth and influence and access to the best stars and acts of the East Coast, the Sullivan \& Considine circuit became a major vaudeville force in the West Coast. The orpheum, located at 4 th \& Stark, also opened in 1904. Built by W. A. and Frank Simons, James MCDevitt, and "Kit" Carson of the Orpheum Amusement Company, the theater promoted itself as a vaudeville venue but operated as a saloon. Despite a poor reputation, however, the orpheum provided the initial home of one of the three major-circuit family vaudeville outlets to continue in Portland after 1906. In October 1905, Keating \& Flood opened the establishment as the Liberty Theater. Two months later they sold their lease to Alexander Pantages, who renamed it the Pantages Theater. Competing furiously for dominance with the Sullivan \& Considine circuit, the Pantages exhibited West Coast vaudeville. ${ }^{19}$

Beginning in 1904, all of Portland's vaudeville theaters were subjected to municipal safety regulations. 
Fire safety was a leading concern of Portland's city Council. After a disastrous fire at Chicago's Iroquois Theatre in early 1904, the city council's executive committee commissioned a report on the fire safety status of Portland's theaters. The document's conclusions led city councilman A. K. Bentley to recommend in June 1905 that two firemen should be posted in each theater during performances. Although the city council postponed action on the proposal until 1906, it announced that it expected immediate compliance with existing laws. Equated with notions of modernity and efficiency, fire safety was consistent with the concept of respectability that family vaudeville theaters sought. When the Star, Arcade, and Lyric opened and noted fire-proof brick construction, spacious aisles, or many emergency exits, owners could boast that they were bound by the same regulations as the legitimate stage theaters. ${ }^{20}$

Theater fire code revision and rigorous enforcement were characteristic of the Progressive Era's urge to address troublesome products of America's changing urban society. Just as typical were attempts by social guardians to ensure predominance of Victorian cultural standards in the face of foreign and lower class influences. Despite its evolution into family entertainment, vaudeville drew criticism from both religious and middle class representatives. At issue was the mixing of respectable patrons with "low-brow" 
audiences of workers and immigrants.

The situation was compounded by the fact that downtown Portland vaudeville and film theaters such as the Fredericksburg Music Hall and Fritz's New Theater were thinly disguised saloons. These facilities presented a palpable reminder of vaudeville's origins in the vice culture and contributed to the poor reputation of vaudeville's fare and devotees. Motion pictures also caused controversy. Peep show machines could be found in restaurants, waiting rooms, hotel lobbies, and in numerous arcades. Offering a variety of risque and off-color parodies, arcades based their income on the attendance of children. ${ }^{21}$

Disdain over the new amusements developed into outrage in 1905 when the impending Lewis \& Clark Centennial Exposition prompted civic leaders to denounce Portland's variety of cheap entertainment. Anxiety over social morality led local women's groups to demand more intense police scrutiny of the arcades in order to protect children from their influence. Family vaudeville theaters also were at risk. They soon faced increasing criticism for openly courting children and running crude and pointless fare. Religious leaders further objected to Sunday theatergoing, which they considered sinful, despite the fact that oregon had legalized it in 1903. In 1906, J. H. Leiper, field secretary of the Northwest Sabbath Association, spoke out 
against Sunday theater in 1906. Oregon's United Presbyterians also lobbied for a state law to renew the Sunday theater prohibition. Insistence on maintaining the lucrative sunday operations only encouraged divisions between the theaters and religious groups such as the Epworth League. ${ }^{22}$

Arcade owners never apologized for their clientele or entertainment quality. Vaudeville operators, in turn, usually preferred to let advertisements do their talking. Responding to a proposed Iicensing fee for Portland's vaudeville theaters in December 1904, however, local managers warned the City Council that their business was "a great moral agency" because it diverted people from the saloons. Despite being held in low regard by much of the city, family vaudeville's establishment had succeeded in creating Portland's first regular motion picture theaters in the early years of the century. Vaudeville established standards of presentation and audience appeal that later would be approximated by new forms of movie presentation. ${ }^{23}$ 
CHAPTER I NOTES

1. E. Kimbark MacColl, Merchants, Money And Power: The Portland Establishment 1843-1913 (Portland, 1988), pp. 187$8,261,264,288,303 .$, E. Kimbark MacColl, The Shaping of A City (Portland, 1976), pp. 111-13.

2. MacColl, Shaping, pp. 143,145,149-50,171-6,185200,213-14., MacColl, Merchants, pp. 288-91,313,319-24,329.

3. MacColl, Shaping, pp. 133-36,179-80.

4. William Toll, The Making of An Ethnic Middle Class: Portland Jewry Over Four Generations (New York, 1982), pp. 15,31., Gordon DeMarco, A Short History of Portland (San Francisco, 1980), pp. 47-57., Steven Lowenstein, The Jews of oregon 1850-1950 (Portland, 1987), pp. 48,66., E. Kimbark MacColl, Merchants, Money, And Power: The Portland Establishment 1843-1913 (Portland, 1988), pp. 107,134,185-88. 5. Gordon Hendricks, The Kinetoscope (New York, 1966), pp. 13,15,40,60,64., Terry Ramsaye, A Million And One NightsA History of The Motion Picture Through 1925 (New York, 1926), pp. 71,213,223., Anthony Slide, Early American Cinema (New York, 1970), pp. 8., Tino Balio in Richard MacCann ed., The First Tycoons (Metuchen, NJ, 1987), pp. 13.

The first Kinetoscopes on the West Coast were offered in June 1894 in San Francisco. The Baker City location presented 
Kinetoscopes a few months after Portland's debut.

6. Advertisement, Oregonian (June 21, 1896), sec. 1 p. 13. Sanborn Map of Portland (corrected to 1898)., Ramsaye, Million, pp. $12,107,108,110,251$., Hendricks, Kinetoscope, pp. 12 .

7. Ibid., Hendricks, Biograph, p. 1., Ramsaye, Million, pp. $143,167,195,209,232,222,223,269,276,309-10$., Robert Sklar, Movie-Made America (New York, 1975), p. 13.

8. May, Screening, pp. 15-17., Sklar, Movie-Made, p. 4 .

9. William M. Kramer, "David Solis-Cohen of Portland: Patriot, Pietist, Litterateur and Lawyer", Western States Jewish Historical Quarterly (January, 1982), p. 148., Dean Collins, "Among Our Neighbors", Oregon Journal (November 14, 1939), sec. 1 p. 10., "The Vitascope At Cordray's", Evening Telegram (December 5, 1896), sec. 1 p. 7., Advertisement (Cordray's), Oreqonian (December 6, 1896), sec. 1 p. 13., "Edison's Vitascope At Cordray's", Oregonian, (December 6, 1896), sec. 1 p. 13., "The Vitascope Is Promised At Cordray's For Tonight", Oregonian (December 7, 1896), sec. 1 p. 5., "The Vitascope At Cordray's Tonight", Evening Telegram, (December 7, 1896), sec. 1 p. 5., "The Vitascope At Cordray's", Oregonian (December 8, 1896), sec. 1 p. 10., "The Viascope(sic) at Cordray's", Evening Telegram (December 8, 1896), sec. 1 p. 6., "The Vitascope A Success", Evening Telegram (December 10,1896), sec. 1 p. 4.,"The Vitascope At 
Cordray's", Oregonian (December 11, 1896), sec. 1 p. 5., "Matinee At Cordray's Tomorrow", Evening Telegram (December 11, 1896), sec. 1 p. 4., "The Vitascope At Cordray's", Evening Teleqram (December 12,1896 ), sec. 1 p. 7 , "New Pictures In The Vitascope", Oreqonian (December 13, 1896), sec. 1 p. 13., "Amusements", Oregonian (December 14, 1896), sec. 1 p. 5., "New Pictures In The Vitascope", Evening Telegram (December 14,1896 ), sec. 1 p. 6 .

10. "The Viascope(sic) At Cordray's", Evening Teleqram (December 8, 1896), sec. 1 p. 6., "The Vitascope At Cordray's", Oregonian (December 8, 1896), sec. 1 p. 10., "The Vitascope At Cordray's", Evening Telegram (December 12, 1896), sec. 1 p. 7., "Amusements", Oregonian (December 14, 1896), sec. 1 p. 5., "New Pictures In The Vitascope", Evening Telegram (December 14, 1896), sec. 1 p. 6 .

11. Ramsaye, Million, pp. 282,287., Advertisement Marquam Grand, Oregonian (August 1, 1897), sec. 1 p. 13., "Jeffries-Sharkey Contest", Oreqonian (March 4, 1900), sec. 1 p. 17 .

The film apparently projected poorly at the Heilig, giving a flickering and shaky picture.

12. "The Electrograph", Oregonian (August 7, 1897), sec. 1 p. 12., "Crowd At The Armory", Oregonian (August 8, 1897 ), sec. 1 p. 10 .

13. MacCann, Tycoons, p. 15., Ramsaye, Million, pp. 165,232,309-311,362., Advertisement (Cordray's), oregonian 
(April 10, 1898), sec. 1 p. 15., Sanborn Map of Portland, (corrected to 1898)., "High Class Specialties", Oreqonian (May 15, 1898), sec. 1 p. 15., "Edison And The War", Oregonian (July 24,1898 ), sec. 1 p. 15 .

14. Hendricks, Biograph, pp. 30-31,34., Ramsaye, Million, pp. 213,313,327,408., Kemp Niver, Biograph Bulletins 1896-1908 (New York, 1974), 59., "Jeffries-Sharkey Contest"., Advertisement - YMCA, Oregonian (April 15, 1900), sec. 1 p. 17., "Passion Play Pictures", Oregonian (April 18, 1900), sec. 1 p. 8., "Audience Was Affected", Evening Telegram (April $18,1900)$, sec. 1 p. 7.

15. Robert $w$. Snyder, The Voice of The City: Vaudeville And Popular Culture In New York (New York, 1989), pp. 3-29., Douglas Gilbert, American Vaudeville: Its Life And Times (New York, 1940), pp. 10,13,14,110,113,120,121,124,126,198,200, 201., "Shields' New Vaudeville", Oregon Journal (May 23, $1903)$, sec 1 page 10 .

16. Gilbert, Vaudeville, p. 156., "Biograph Pictures At 'Silver King'", Oregonian (May 31, 1902), sec. 1 p. 10., "Mr. Shields' New Venture", Oregonian (June 8, 1902), sec.p. 18., "Shields' Concert Park", Oregonian (June 15, 1902), sec. 1 p. 21., "Shields' Park", Oreqonian (June 21, 1902), sec. 1 p. 8., "Shields' Park", Oregonian (June 24, 1902), sec. 1

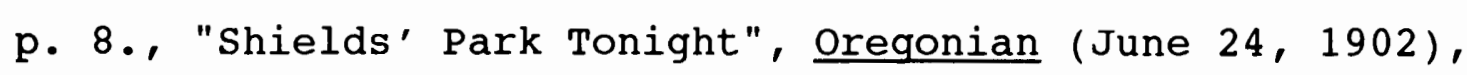
sec. 1. p. 19., "Shields' Park", Oregon Journal (June 28, 1902), sec. 1 p. 8., Advertisement - Shields' Park, Oregon 
Journal (June 28, 1902), sec. 1 p. 8., "Shields' Park", Oregonian (June 29, 1902), sec. 1 p. 19., "Crowd At Shields"

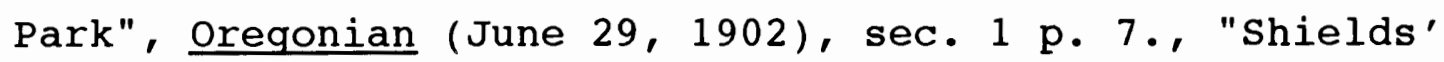
Park Program", Oregonian (July 2, 1902), sec. 1 p. 5., "Shields' Park Tonight", Oregonian (July 3, 1902),

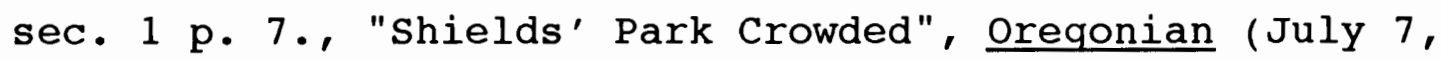
1902 ), sec. 1 p. 5., "All Records Broken", Oregonian (July 9, 1902), sec. 1 p. 14.,"Crowds Turned Away", Oreqonian (July 14, 1902), sec. 1 p. 5., "Shields' Park", Oreqonian (July 14, 1902), sec 1. p. 5., "Show In The Rain", Oreqonian (July 15, 1902), sec. 1 p. 7., "Good Show", Oregon Journal (July 17, 1902), sec. 1 p. 5., "Shields' Park", Oregon Journal (July 19, 1902), sec. 1 p. 5., "New Bill At Shields' Park", Oregonian (July 20, 1902), sec. 1 p. 24., "Shields' Greatest

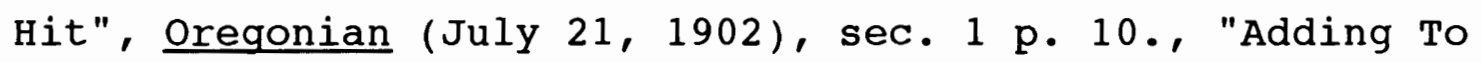
Shields' Park", Oregon Journal (July 22, 1902), sec. 1 p. 5., "Shields' Park Addition", Oregonian (July 24, 1902), sec. 1

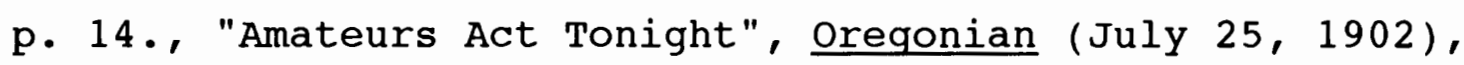
sec. 1 p. 10., "Shields' Park", Oregon Journal (July 26, 1902 ), sec. 1 p. 5., "New Bill At Shields' Park", Oregonian (July 27, 1902), sec. 1 p. 8., "Shields' Park Show", Oregon Journal (July 28, 1902), sec. 1 p. 5., "Shields Has Great Show", Oregonian (July 28. 1902), sec. 1 p. 5., "Demontrello Is Injured", Oregonian (July 29, 1902), sec. 1 p. 10., "Shields' Crowds Increase", Oregon Journal (July 31, 1902), sec. 1 p. 14., Advertisement - Shields' Park, Oregon Journal 
(August 2, 1902), sec. 1 p. 8., "Shields' Park Is Packed", Oregonian (August 4,1902), sec. 1 p. 5., Advertisement Shields' Park, Oregon Journal (August 9, 1902), sec. 1 p. 8., "New Theater Promised", Oreqon Journal (August 9, 1902), sec. 1 p. 8., Advertisement - Shields' Park, Oregonian (August 10, 1902), sec. 1 p. 24., "Shields' Program Good", Oregon Journal (August 11, 1902), sec. 1 p. 5., "New Bill At Shields'", Oregonian (August 17, 1902), sec. 1 p. 24., "Shields' Park", Oregon Journal (August 18, 1902), sec. 1 p. 5., "Programme At Shields'", Oregonian (August 18, 1902), sec. 1 p. 10. , "Crowd Stays By Shields", Oregonian (August 19, 1902), sec. 1

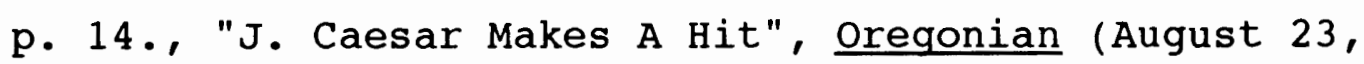
1902 ), sec. 1 p. 8., "At Shields' Park", Oregonian (August 25, 1902), sec. 1 p. 5., "Shields' Big Clientele", Oregonian (August 26, 1902), sec. 1 p. 8., "Amateurs At Shields"", Oregonian (September 3, 1902), sec. 1 p. 9., "A Theater For Shields?", Oreqonian (September 6, 1902), sec. 1 p. 16., "BY Mr. Shields", Oreqon Journal (September 6, 1902), sec. 1 p. 8., "Standing Room At Shields", Oregonian (September 8,

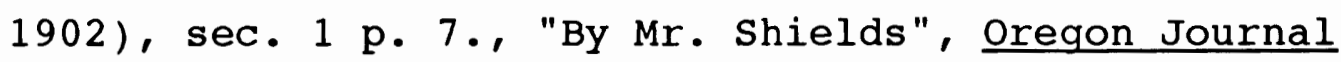
(September 13, 1902), sec. 1 p. 5., "Vaudeville At Cordray's", Oregon Journal (April 25, 1903), sec. 1 p. 12., "Shields' Great Acts", Oregonian (April 26, 1903), sec. 1 p. 26., "Continuous Vaudeville", oregonian (May 3, 1903), sec. 1 p. 26., "Shields Receives Roosevelt Views", Oregon Journal (June 4, 1903), sec. 1 p. 7., "New Bill of Vaudeville", 
oregon Journal (June 6, 1903), sec. 1 p. 12., "To see The President", Oregonian (June 7, 1903), sec. 1 p. 26., "Shields' Vaudeville", Oregon Journal (June 8, 1903), sec. 1 p. 7., "Continuous Vaudeville", oreqon Journal (June 9, 1903), sec. 1 p. 7., "Shields' Popular Vaudeville", Oreqonian (June 13, 1903), sec. 1 p. 7., Advertisement Shields' Park, Oregonian (June 21, 1903), sec. 1 p. 27., "Shields' Park Opens", Oreqon Journal (June 23, 1903), sec. 1 p. 7., "Shields' Park Opens", Oregonian (June 23, 1903), sec. 1 p. 7., "Shields' Big Bill", Oregon Journal (July 4, 1903), sec. 1 p. 14., "Open Air Vaudeville", Oregonian (July 19, 1903), sec. 1 p. 18., "Shields' Park", Oregon Journal (July 22, 1903), sec. 1 p. 20., "Saints Win Series", Oregonian (August 3, 1903), sec. 1 p. 5., "Baseball Pictures At Shields' Park Next Week", Oregon Journal (August 13, 1903), sec. 1 p. 8., "Local Features At Shields'", Oregon Journal (August 14, 1903), sec. 1 p. 7., "Baseball At Shields"", Oregon Journal (August 15, 1903), sec. 1 p. 15., "Baseball At Shields' Park", Oregonian (August 16, 1903), sec. 1 p. 20., "Shields' Opening", Oregon Journal (August 17, 1903), sec. 1 p. 7., "At Shields' Park", Oregon Journal (August 19, 1903), sec. 1 p. 7., "At Shields' Next Week", Oregon Journal (August 26, 1903), sec. 1 p. 7., "Empire Top Line Vaudeville", Oregon Journal (June 9, 1903), sec. 1 p. 7.,"Opening of The Empire", Oregon Journal (June 11, 1903), sec. 1 p. 5., "Advance Sale of Seats", Oregon Journal 
(June 12, 1903), sec. 1 p. 7., Advertisement - Empire, Oreqonian (June 14, 1903), sec. 1 p. 24., Advertisement Empire, Oreqonian (June 14, 1903), sec. 1 p. 7., "New Theater Finished", Oreqonian (June 14, 1903), sec. 1 p. 24., "The Empire", Oregon Journal (June 25, 1903), sec. 1 p. 7., "The Empire", Oreqon Journal (July 20, 1903), sec. 1 p. 7., "Empire", Oregonian (August 9, 1903), sec. 1 p. 18., "The Empire's New Bill", Oreqonian (August 23, 1903), sec. 1 p. 18., "The Lyric Opens Monday", Oregon Journal (May 8, 1904), sec. 1 p. 16., Advertisement - Lyric, Oregonian (May 8, 1904), sec. 1 p. 19., "The Star's Opening", oregon Journal (June 13, 1904), sec. 1 p. 12., "Star Theatre's Opening", Oregon Journal (June 16, 1904), sec. 1 p. 5., Oregon Journal (June 17, 1904), sec. 1 p. 10., "This Week At The Lyric", Oregon Journal (June 28, 1904), sec. 1 p. 7., "Star Theatre", Oregon Journal (July 3, 1904), sec. 1 p. 13., "At The Star", Oregon Journal (July 6, 1904), sec. 1 p. 7., "Next Week At The Star", Oregon Journal (July 8 1904),

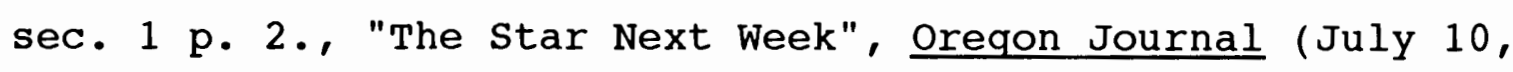
1904 ), sec. 1 p. 14., "Cool At The Star", Oregon Journal (July 11, 1904), sec. 1 p. 8., "At The Star", Oregon Journal (July 17, 1904), sec. 1 p. 14.,"The Lyric", Oregonian (July 24, $1904)$, sec. 1 p. 18., "Star's clever offering", Oregon Journal (September 6, 1904), sec. 1 p. 5., "Society At The Grand", Oregon Journal (January 6, 1905), sec. 1 p. 10., "Negro Was Refused Admission To Box", Oregon Journal (March 
2, 1905), sec. 1 p. 8., "Vaudeville Shows Will Raise Prices", Oregon Journal (March 10, 1905), sec. 1 p. 3., "Negroes May Be Barred From Theatre Boxes", Oregon Journal (May 18, 1905), sec. 1 p. 6., "Christmas At Pantages", Oregon Journal (December 24, 1905), sec. 1 p. 18 .

17. Ramsaye, Million, pp. 363., Portland City Directory $\underline{1902}$., "Slot Machines Go Back", Oregon Journal (August 1, 1902), sec. 1 p. 6., "Outdoor Vaudeville", Oreqonian (April 26, 1903), sec. 1 p. 26., Advertisement - Central Park, Oregonian (April 26, 1903), sec. 1 p. 27., "Central Park Vaudeville", Oregonian (May 10, 1903), sec. 1 p. 26., Advertisement - Central Park, Oregon Journal (April 25, 1903), sec. 1 p. 13., "Outdoor Vaudeville", Oregon Journal (May 2, 1903), sec. 1 p. 12., "Empire - Top Line Vaudeville", Oregon Journal (June 9, 1903), sec. 1 p. 7., "New Theater Finished", Oregonian (June 14,1903), sec. 1 p. 17., Advertisement Empire, Oregonian (June 14, 1903), sec. 1 p. 27., "New Theatre Is Now Being Built", Oregon Journal (October 9, 1903 ), sec. 1 p. 7., "New Arcade Opens", Oregon Journal (October 13, 1903), sec. 1 p. 7., "'Continuous Vaudeville' Popular", Oregon Journal (October 14, 1903), sec. 1 p. 7., "Arcade's Big Bill", Oregonian (October 18, 1903), sec. 1 p. 18., "Arcade Prospers", Oregon Journal (October 15, 1903), sec. 1 p. 7., "Arcade", Oregon Journal (October 17, 1903), sec. 1 p. 15., "Battle Over Arcade Theatre", Oregon Journal (November 4, 1903), sec. 1 p. 5., "At The 
Empire", Oregon Journal (November 7, 1903), sec. 1 p. 17., Advertisement - Empire, Oregonian (November 8, 1903), sec. 1 p. 19., "Empire", Oregonian (November 8, 1903), sec. 1 p. 18., "At The Arcade Theatre", Oregon Journal (January 1, $1904)$, sec. 1 p. 7., "At The Arcade", Oreqon Journal (January 8, 1904), sec. 1 p. 13., general weekly theater comments, Oreqon Journal (January 30, 1904), sec. 1 p. 15., "At The Arcade", Oregon Journal (February 15, 1904), sec. 1 p. 7., "Plans of Manager Shields", Oregonian (April 24, $1904)$, sec. 1 p. 18., "Arcade Theatre Entertains", Oregonian (May 1, 1904), sec. 1 p. 18., "Arcade Theatre", Oregon Journal (May 13, 1904), sec. 1 p. 7., "Opening Near At Hand - Shields' Park", Oregonian (June 12, 1904), sec. 1 p. 18., "Shields' Park Opening", Oregon Journal (June 19, 1904), sec. 1 p. 15., "Shields' Season Abruptly Ended", Oregon Journal (August 8, 1904), sec. 1 p. 2., "At The Up To Date Arcade", Oregonian (May 15, 1905), sec. 1 p. 18 .

18. Elliott, Vaudeville, pp. 62., Portland City Directory 1905, p. 607., Advertisement - Bijou, Oreqonian (April 24, 1904), sec. 1 p. 19., Advertisement - Bijou, Oregon Journal (April 24, 1904), sec. 1 p. 17., "Opening of The Lyric", Oregonian, (May 8, 1904), sec. 1 p. 18., Advertisement - Star, Oregonian (June 19, 1904), sec. 1 p. 19., "Star Opens June 10", Oregon Journal (June 10, 1904), sec. 1 p. 5., "Star Opens June 20", Oregon Journal (June 10, 1904), sec. 1 p. 3., "Star Theatre", Oregon Journal (June 15, 1904), sec. 1 p. 4., 
Advertisement - Star, oregonian, (June 19, 1904), sec. 1 p. 19., "At The Bijou", Oregon Journal (July 3, 1904), sec. 1 p. 13.," Emmett At The star", Oregon Journal (July 31 , 1904 ), sec. 1 p. 11., Advertisement - Lyric, Oregon Journal (September 20, 1904), sec. 1 p. 5., "No Theater Yet For Blanche Bates", Oreqon Journal (January 11, 1905), sec. 1 p. 3.

19. Elliott, Vaudeville, pp. 52-56, 58-59., Gilbert, Vaudeville, pp. 219., Advertisement - Orpheum, Oregon Journal (April 24, 1904), sec. 1 p. 17., "Police May Close Orpheum Soon", Oregon Journal, (July 29, 1904), sec 1 page 2., "Theatre Trouble Settled Out of Court", Oregon Journal (September 9, 1904), sec. 1 p. 6., "Just How John F. Cordray Ran Mechanical Clock Into Theatre That Sold For $\$ 50,000 "$, Oregon Journal (November 6, 1904), sec. 1 p. 15., "Grand Opens Soon", Oregon Journal (November 20, 1904), sec. 1 p. 16., Advertisement - Grand, Oregonian (November 20, 1904), sec. 1 p. 19.,"Many Saloons May Not Get Licenses", Oregon Journal (December 22, 1904), sec. 1 p. 5., "Licenses Given To Lawbreakers", Oregon Journal (December 30, 1904), sec. 1 p. 5., "Actress Has Narrow Escape From Death", Oregon Journal (January 16,1905 ), sec. 1 p. 12, " Shenke Acrobats And The Grand", Oregon Journal (March 30, 1905), sec. 1 p. 8., "Empire Theatre Has Been Leased", Oregon Journal (April 2, 1905), sec. 1 p. 7., "Soft Drinks only At Orpheum", Oregon Journal (May 19, 1905), sec. 1 p. 6., "Lyric Crowd To Get 
Orpheum", oregon Journal (September 24, 1905), sec. 1 p. 9., "Grand Opening of The Liberty", Oregon Journal (October 26, 1905), sec. 1 p. 5., "The Liberty Opens Today", Oreqon Journal (October 30, 1905), sec. 1 p. 11., "Pantages, of Seattle, Buys Liberty Theatre For $\$ 20,000 "$, Oregon Journal (December 14, 1905), sec. 1 p. 6., Advertisement - Pantages, Oreqonian (December 24, 1905), sec. 1 p. 29., "Russell And Cordray Race To East", Oregon Journal (January 1, 1906), sec. 1 p. 3., general weekly stage comments, Oregon Journal (May 13, 1906), sec. 1 p. 18., "Star Closed This Week", Oregon Journal (August 13, 1906), sec. 1 p. 18 .

20. "Fire Regulations For The Theatres", Oregon Journal (June 7, 1905), sec 1 p. 8., "Fire Protection In Theatres", Oregon Journal (August 20, 1905), sec. 1 p. 5., "Theatres Must Protect Patrons From Fire", Oregon Journal (September 8, 1905), sec. 1 p. 13., "Theatres Must Install Fire Protection", Oregon Journal (October 7, 1905), sec. 1 p. 5., "Theatres Comply With Fire Rules", Oregon Journal (October 11, 1905), sec. 1 p. 8., "Local Theatres Must observe Fire Rules", Oregon Journal (October 20, 1905), sec. 1 p. 6., "Theatres To Be Made Safe", Oregon Journal (October 21, 1905 ), sec. 1 p. 6., "Marquam Closes For Good", Oregon Journal (March 22, 1906), sec. 1 p. 8.

21. Advertisement - Fredericksburg, Oregon Journal (September 2, 1902), sec. 1 p. 5., Advertisement - Fritz's New Theatre, Oregon Journal (September 8, 1902), sec 1 p. 5., 
Advertisement - Fredericksburg, oregon Journal (October 6, $1902)$, sec. 1 p. 5.

22. Gloria Elizabeth Myers, "Lola G. Baldwin and the Professionalization of Women's Police Work, 1905-1922" (M.A. Thesis - Portland State University, 1993), pp. 21-22., "Epworth Leaguers Plan Conference", Oregon Journal (October 14, 1904), sec. 1 p. 11.,"Very Cheap And Nasty", Oregon Journal (May 17, 1905), sec. 1 p. 1., "Coarse Pictures Must Be Removed", Oreqon Journal (May 19, 1905), sec. 1 p. 3., "Lost Five Dollars In Penny Arcade", Oregon Journal (May 24, 1905), sec. 1 p. 3., J. B. Ziegler, "The Penny Arcades" - letter to editor, Oregon Journal (May 20, 1905), sec. 1 p. 4., "Police After Penny Arcade Fakers", Oregon Journal (November 6, 1905), sec. 1 p. 6., "Sunday Theatres Are Scored", Oregon Journal (October 15, 1906), sec. 1 p. 5., "Would Stop All Sunday Plays", Oregon Journal (April 16, 1906), sec. 1 p.

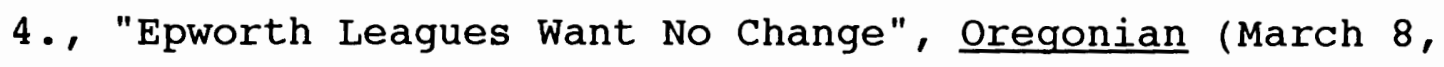
$1908)$, sec. 1 p. 8 .

23. "Managers Will Fight Ordinance", Oregon Journal (December 25, 1904), sec. 1 p. 2., "Increased License on Theatres Beaten", Oregon Journal (January 2, 1905), sec. 1 p. 6 . 


\section{CHAPTER II}

THE NICKELODEON AND THE ERA OF TRANSITION, 1906-1910

Building on the vaudeville legacy, Portland's first successful motion picture theater opened in Portland in 1906. Packaged as "nickelodeons", the new institutions expropriated the conventions, promotional approaches, and audiences of vaudeville. Within two years, sophisticated story telling techniques would dramatize these products. Such advances would be supplemented by promotional approaches designed to broaden the class base of the motion picture audience.

Nickelodeons were characteristically crude theaters. Most often, they were established in vacant business space originally designated for use as saloons or stores. A projection booth was constructed near the street entrance, and the entire space beyond accommodated rows of chairs or benches facing the back wall which often usually held a canvas sheet. One hundred people would usually crowd a nickelodeon. For a nickel they trod dusty wooden floors to hard seats and watched one and two minute films to the accompanying screech of projection machinery.

The Nickelodion, Portland's first theater devoted 
primarily to motion pictures, opened on 6 th street in August 1906. Established by Joseph A. St. Peter in a small section of the Concordia Club building, the theater continued functioning for four years. A Nickelodion East even appeared for a short period on Grand Avenue on the east side of the Willamette River. Two other Portland film theaters soon appeared, although both lasted less than a year. A Hale's Tours of The World franchise, opened in a storefront on 6 th Street, showed travel films based on exotic scenic locations. The theater resembled a large open-ended streetcar from which audiences experienced a vicarious sense of motion. The second theater was unnamed and showed films free of charge in a non-theatrical building at $3 \mathrm{rd}$ and Morrison. ${ }^{1}$

Portland's moving picture industry blossomed when $\mathrm{S}$. Morton Cohn formed the Imperial Amusement Company in 1907. Cohn's chain of outlets included the orpheum on 6th street, and the Palace on 1st, both from former storefronts, and a storefront theater called the Hippodrome. His most significant holding was the Star, built as a vaudeville theater a few years earlier. A larger building than any previous structure adapted to the regular exhibition of motion pictures, it was also the first of its type to use a facility specifically built as a theater. The star opened tentatively in $1909 .^{2}$

While film continued to appear occasionally in 
Portland's legitimate and vaudeville theaters, the prestige of vaudeville plummeted after 1906. Film activity centered on the novel nickelodeons. Local and regional distributors now supplied manufacturers' products to fill movie bills that changed at least once a week. In 1905, Miles Brothers established the first apparent Portland distribution base through its agent, Daniels Dillwyn. Four years later, s. Morton Cohn set up the Morton Film Exchange to exclusively supply his theaters through cooperation with a film exchange operated by Portland resident Harley Stevens, Jr. ${ }^{3}$

Both the makeshift nature of nickelodeon theater buildings and the new business opportunities presented by motion picture film provoked unprecedented theater conventions. The combination of smaller seating capacity and the repetitive qualities of film allowed nickelodeons to maintain longer daily business hours than vaudeville. Without live performers there was no limit on the number of times a film could be shown. In fact, repeated performances could make up for sparse attendance and limited seating. Likewise, low overhead costs enabled operations to charge between five and ten cents admission. Nickelodeons compared themselves to vaudeville by emphasizing their similarity as cheap entertainment. ${ }^{4}$

The new theaters also emulated vaudeville in the structure of their presentations. Between 1906 and 1910, motion pictures typically devoted each reel to a single 
topic. Each film was no more than ten minutes long. While complex film stories were still rare, most presentations were identifiable by their basic theme. Films were noted as dramas, romances, westerns, comedies, and scenics as well as industrial and educational features. Nickelodeons routinely used the vaudeville precedent when establishing a bill of films by choosing six one-reelers. Advertisements described the full variety of topics in each bill. Like vaudeville, each bill played continuously without break or intermission. Just as vaudeville had used film as a novelty device, nickelodeons employed illustrated song singers as an occasional break in the endless round of films. Portland's nickelodeons also emulated their vaudeville predecessors by emphasizing theater cleanliness, intelligent entertainment, and courteous employees. ${ }^{5}$

Although the nickelodeons sought to attract audiences by imitating their vaudeville predecessors, upper and middle-class prejudice against cheap amusements persisted. The consolidation of the motion picture industry, however, initiated a process that helped to universalize the appeal of films. Moving picture camera and projector inventor Thomas A. Edison sought to assert his patent rights by founding a licensing corporation comprising all the major filmmaking companies of the time - Edison, Selig, Kalem, Essanay, Vitagraph, Lubin, Pathe, and Melies. Recreated as the Motion Picture Patents Company in 1908, Edison sought to 
monopolize the American motion picture industry. The MPPC, in turn, cooperated with the newly formed New York Board of Censorship. Organized in 1909 by Protestant social guardians whose goal was to protect children, immigrants, and respectable society from objectionable depictions, the Board sought to regenerate America's crumbling Anglo-Protestant ideals by gaining control of the new and influential medium. After the Board's formation, nickelodeons rarely showed movies which had not passed its review and were not licensed by the Patents Company. Soon, however, recognizing the board's value, emerging independent companies also submitted their products and contributed to its support. Having satisfied these conditions motion picture operators could reassure the middle and upper classes that the medium was under responsible control and guidance. ${ }^{6}$

Simultaneous with the formation of MPPC and the New York censorship board, significant developments in film story telling helped to broaden the medium's appeal. Building on many newly developed aesthetic techniques, D. W. Griffith expressed Protestant values through motion pictures such as 'A Corner On Wheat' (1909) and 'Home Sweet Home' (1914). His concerns for the traditional roles of the family and women in a culturally fluctuating America served the needs of the traditional culture. Griffith's films explored various tensions in the twentieth century's developing urban landscape. A regular source of films addressing their 
anxieties helped draw middle class America to the movies.' Hostility to films in Oregon and Portland emerged through ordinances, legislation, religious pronouncements, and political statements. The overall conception was that motion pictures were tolerated as a borderline vice which might require restrictions if theaters and films continued developing along the lines established with the first nickelodeons. Political action began when the Portland City Council passed a 1908 ordinance that required motion picture theaters to close by $10 \mathrm{p} . \mathrm{m}$. in order to reduce the temptations for children. The next year, state senator Solomon Abraham introduced a bill to repeal the 1903 law allowing sunday theater showings; local ministers Benjamin Young and W. H. Sellick lobbied in salem for its passage. One issue argued between the bill's detractors and supporters was why Mayor McClellan closed the nickelodeons in New York on December 25, 1908. Mr. Quackenbush, in support of Abraham's bill, claimed it was because the nickelodeons were wreckers of youth. George Baker retorted that they were closed because they didn't meet city fire ordinances. Although Abraham's bill died in committee as "too drastic and because a large number of people had filed petitions against it", public concern for the influence of movies on children continued. ${ }^{8}$

Adding to concerns over the physical health of minors resulting from poor projection in darkened rooms, social 
workers and purity crusaders attacked movies for stupefying the minds of children and damaging their ability to grow into responsible citizens. Beyond the oregonian's determination that nickelodeons were "dark, dreary and dirty", was the belief that films induced "neurasthenia" in children. Indeed, on May 2, 1910, Reverend William Hiram Foulkes blamed "immoral moving pictures" for encouraging juvenile delinquency. Like vaudeville, motion picture operators found that the industry's reputation was tainted by the fact that movies relied on saloons for a portion of their patronage. 9

The public relations battle further suffered in March 1908 when peep shows were confiscated and a theater manager was arrested for showing "bizarre" films. The waiting room of the Oregon Water and Power railway at 1st and Alder, which held penny arcade peep show machines, was raided by the police at the urging of the Municipal Association. Founded in 1902, this group began as a Presbyterian committee and disassociated itself from church activities upon its official formation. Comprised of middle class Portland businessmen, it was dedicated to eradicating gambling, prostitution and other vice in Portland. During its first few years, the Association concentrated on police enforcement of anti-gambling laws which often involved agitation against local saloons. ${ }^{10}$

The Municipal Association called the waiting room raid 
the first step in their campaign against "indecent pictures" for the sake of ladies and children in Portland. Responding to complaints, it had commissioned a committee to investigate the waiting room's peep show machines. The situation was then reported to district attorney John Manning, who compelled the police to seize the machines. ${ }^{11}$ The peep show machines in the O.W.P. waiting room were owned by local saloon owner Fred Fritz and his partner J. W. West, who were reputed to own a chain of penny arcades throughout the Northwest as far east as Montana. Fritz was a primary target in the Municipal Association's anti-gambling campaign, suffering arrest for allowing gambling and serving alcohol after two a.m. Fritz seemed to be the only target in the Municipal Association's indecent picture crusade. Three days after the first raid, peep show machines were confiscated from Fritz's saloon on Burnside. The second seizure emphasized the further corruption of debauched saloongoers, not ladies and children. ${ }^{12}$

Despite Fritz and his local partner Mr. Russell's attempt to prove their innocence by offering children one day of free viewings at the O.W.P. waiting room, the case went to trial. But in April 1909 Fritz and Russell were acquitted. Defense lawyer R. E. Moody called the Association a bunch of crackpots, and one member of the acquitting jury was himself a Municipal Association member. ${ }^{13}$

Another instance of arrest involving film presentation 
resulted from a private citizen's complaint. A woman happened to patronize the Model Theater on North Third Street in 1910 and was shocked by what she said were "bizarre scenes." She reported this to the police who dispatched plainclothes officers Long and Montgomery to investigate. Frederick Nesme, a Frenchman who spoke no English, was arrested for "exhibiting immoral pictures."14

Even without actual criminal charges or specific examples motion pictures were still linked with crime. In March 1909 a tramp broke into a boarding house room and exchanged his tattered attire for the tenant's clothing. Although this was an isolated incident involving nothing more, the article's headline read, "Like Moving Picture Plot." A common act of thievery was reflexively equated with the entertainment available through motion pictures. ${ }^{15}$ Nickelodeons also emulated vaudeville predecessors by achieving respectability by submitting to city safety regulations. Relevant city ordinances concentrated most frequently on fire safety between 1906 and 1910. The celluloid base upon which moving pictures were adhered was a nitrate composition close in chemical content to gun cotton. It was easily combustible and once burning, was virtually inextinguishable. Between 1907 and 1910, local newspapers reported at least twelve motion picture fires in worldwide locations ranging as far as China. Four of them occurred in Oregon, two in Portland. In March 1909, reels of stored film 
in Samuel Newman's theatrical supply warehouse spontaneously combusted. Just three months later, the Orpheum Theater on 6 th managed to confine a nitrate fire to the projection booth. ${ }^{16}$

Makeshift sites only increased the danger of fire and injury. Hale's Tours, for example, was in a store location which continued to be used for motion pictures after the outfit abandoned it. The structure was built primarily of wood frame, obviously at great risk when there was a likelihood of fire. Nor did it have proper fire exit configurations allowing patrons to leave in the event of an emergency. Stores were built to different specifications than theaters, defying significant modifications. The available exit in most theaters was the main entrance on the street, which in case of a fire, could be blocked off by a projection booth fire at the rear of the theater. ${ }^{17}$

In January 1908, active interest in movie theater fire safety was revived by a disastrous fire at a Boyertown, Pennsylvania facility, which killed one hundred and seventy people. In direct response to the disaster, Portland's building inspector assured the City Council that Portland's theaters were safe, although he neither addressed nickelodeons nor makeshift theaters. ${ }^{18}$

Renewed interest in fire safety also revived the proposal to station firemen in the city's theaters. While the measure never was adopted, the Council passed another 
ordinance in June that dealt specifically with nickelodeons. The new regulation prohibited motion picture shows from functioning in frame buildings. Yet Councilman and theaterowner George Baker added a provision "exempting all frame buildings that have been used as theaters for one year." The following year, city building inspector Dobson, with the support of Fire Chief David Campbell, recommended an ordinance limiting the use of frame theaters to a two-year period. Although not adopted, the writing was clearly on the wall for Portland's frame theaters. ${ }^{19}$

The use of local ordinances to help elevate the legitimacy of nickelodeons typified a transitional phase in the development of motion picture theaters in Portland. National developments in the industry's business structure and aesthetic advances in film storytelling first allowed motion picture theaters to distinguish themselves from vaudeville predecessors. Their appeal to affluent and respectable audiences would soon be more secure. 
CHAPTER II NOTES

1. Niver, Biograph Bulletins., Ramsaye, Million, pp. 428-432., Portland City Directory 1906, p. 1344., Portland City Directory 1907-08, pp. 963,1497,1550., Portland City Directory 1909, pp. 1027,1631., Portland City Directory 1910, p. 1519., portland City Directory 1911, pp. 571,1064,1899., Portland City Directory 1912, pp. 594,1933., Portland City Directory 1915., pp. 493,892,1551., Dean Collins, "Among Our Neighbors", Oregon Journal (June 1, 1940), sec. 1 p. 6., Advertisement - Hale's Tours, Oregon Journal (March 11, 1906), sec. 1 p. 19., Advertisement - Nickelodion, Oregon Journal (August 2, 1906), sec. 1 p. 7.

2. Portland City Directory 1911, p. 1899., Advertisement - Star, Oregonian (July 7, 1908), sec. 1 p. 11., Advertisement - Star, oregon Journal (July 8, 1908), sec. 1 p. 9., "New Pictures That Talk", Oregonian (July 6, 1908), sec. 1 p. 7., "A New Theater", Oreqonian (February 25, 1909), sec. 1 p. 9., Advertisement - Arcade, Oregonian (October 3, 1909), sec. 4 p. 3., "National Theater Sold", Oregonian (May 9, 1910), sec. 1 p. 7 .

3. Eugene Clinton Elliott, A History of VarietyVaudeville In Seattle From The Beginning To 1914 (Seattle, 1944), pp. 59,60., Balshofer and Miller, one Reel, pp. 10-11., Tino Balio in MacCann, Tycoons, p. 16., Ramsaye, 
Miliion, pp. 402-03., Portland City Directory 1907-08, p. 436., Portland City Directory 1910, pp. 125,680,1062, 1194,1463., "Melvin G. Winstock Saved Maryland", Oregon Journal (November 14, 1904), sec. 1 p. 5., Advertisement Hale's Tours, Oregonian (March 11, 1906), sec. 1 p. 19., "Marquam Closes For Good", Oreqonian (March 22, 1906), sec. I p. 8., "Marquam To Reopen May 15", Oreqonian (May 5, 1907), sec. 1 p. 37., Advertisement Marquam Grand, Oregonian (January 4, 1908), sec. 1 p. 7., Advertisement - Marquam Grand, Oregonian (March 8, 1908), sec. 4 p. 5., Advertisement - Marquam Grand, Oregonian (March 29, 1908), sec. 4 p. 5., "First Time In The City", Oregonian (July 7, 1908), sec. 1 p. 11., "Passion Play Pictures", Oregonian (January 2, 1908), sec. 1 p. 10., "Passion Play Pictures", Oregonian (January 3, 1908), sec. 1 p. 9., Advertisement Orpheum, Oregonian (August 14, 1908), sec. 4 p. 3., "Heilig To Be Reopened", Oregonian (July 20, 1909), sec. 1 p. 9 .

4. "Star Is Popular", Oregon Journal (June 22, 1904), sec. 1 p. 12., Advertisement - Hale's Tours, Oregon Journal (March 11, 1906), sec. 1 p. 19., Advertisement - Nickelodion, Oregon Journal (August 2, 1906), sec. 1 p. 7., Advertisement Star, oregonian (January 31, 1909), sec. 4 p. 3., Advertisement - Star, Oregonian (April 18, 1909), sec. 4 p. 3 . 
5. Advertisement - Nickelodion, Oregon Journal (August 2, 1906), sec. 1 p. 7., Advertisement - Nickelodion, Oregon Journal (August 7, 1906), sec. 1 p. 7., Advertisement Nickelodion, Oregon Journal (September 1, 1906), sec. 1 p. 9., Advertisement - Nickelodion, oregonian (April 7, 1907), sec. 1 p. 35., "At The Nickelodion", Oregonian (December 16, 1906), sec. 1 p. 34., "Portland's Moving Picture Shows", Oregonian (November 1, 1908), magazine section, p. 6., "Moving Pictures At The Star", Oregonian (October 17, 1909), sec. 4 p. 3., Dean Collins, "Among Our Neighbors, Oregon Journal (June 1, 1940), sec. 1 p. 6. Movie bills were clearly tied to vaudeville concepts. One advertisement boasted of the "greatest actors, comedians, singers and entertainers in the world exhibited in moving pictures." Reviews regularly complimented the star on its "balanced" show. The Nickelodion's entertainment was meant for "ladies, gentlemen and children." The Star was said to "entertain the intelligent," and its staff offered "courteous attention to patrons." The Star was not a dump, it was "bright, clean and above all, worthy of the patronage of the best people of the city."

6. Robert Fisher, "Film Censorship And Progressive Reform: The National Board of Censorship of Motion Pictures, 1909-1922", Journal of Popular Film (1975), pp. 143-47., May, Screening, pp. 55-58., Ramsaye, Million, pp. 465-67., Henderson, Griffith, pp. 5-6., Slide, Early American, p. 81., 
Robert Henderson, D. W. Griffith: The Years At Biograph, (New York, 1970), p. 56., Fred J. Balshofer and Arthur C. Miller, One Reel A Week, (Berkeley, 1967), pp. 7,12-13,24., MacCann, Tycoons, p. 32., Sklar, Movie-Made, p. 35., "Edison Enters Combine", Oregonian (February 12, 1908), sec. 1 p. 15.,"All Nickelodeons Barred", Oregonian (December 25, 1908), sec. 1 p. 1., "Film Trust To Meet", Oregonian (July 17, 1909), sec. 1 p. 10., "Film Companies Unite", Oregonian (August 7, 1909), sec. 1 p. 9., "National Theater Sold", Oregonian (May 9, 1910), sec. 1 p. 7., Advertisement - Peoples Amusement Company, Oregonian (August 21,1910 ), sec. 4 p. 3 . The MPPC was formed on December 18, 1908. The New York Board began operations in June 1909.

7. May, Screening, pp. 60-95., Sklar, Movie-Made, pp. 48-61., Hampton, History, pp. 49-53,55-56.

May states that Griffith merged "politics, vice-crusading and films..." that "his aesthetics were used to dramatize the cultural tensions of the era, giving them an explicitly Protestant tone" and that his films "suggest that the movies were beginning to portray the concerns of anxious victorians."

8. "Watch In Hand, Policemen Eye Moving Picture Shows", Oregon Journal (May 24, 1908), sec. 1 p. 11., "Red Hot Talk Is Heard At Salem", Oregonian (February 9, 1909), sec. 1 p. 7., "Sunday Rest Bill Killed", Oregonian (February 11, 1909), sec. 1 p. 6., "Baby Murdered In Play - Youthful Holdup Gets Inspiration From Moving 
Pictures", Oregonian (August 19, 1909), sec. 1 p. 1 .

9. "The Moving Picture Craze", Oregonian (March 15, 1908), sec. 1 p. 3., "Portland's Moving Picture Shows", Oregonian (November 1, 1908), magazine section, p. 6., "Red Hot Talk Is Heard At Salem", Oregonian (February 9, 1909), sec. 1 p. 7., "Sunday Rest Bill Killed", Oregonian (February 11, 1909), sec. 1 p. 6., "Baby Murdered In Play - Youthful Holdup Gets Inspiration From Moving Pictures", Oregonian (August 19, 1909), sec. 1 p. 1., "Films Are Blamed", Oregonian (May 2, 1910), sec. 1 p. 10 .

10. "New Reform Move", Oregonian (September 5, 1903), sec. 1 p. 6., "Hunt on Carpet", Oregonian (October 3, 1903), sec. 1 p. 16., "Municipal League Enters The Arena", Oregon Journal (July 20, 1904), sec. 1 p. 2., "Saloon Men Must obey Closing Law", Oregon Journal (December 5, 1904), sec. 1 p. 2., "Fred Fritz Is Found Guilty", Oreqonian (December 17, 1904), sec. 1 p. 2., "Concert Hall Men Are Arrested Again", Oregon Journal (May 17, 1906), sec. 1 p. 10., "An African In Woodpile", Oregon Journal (May 24, 1906), sec. 1 p. 1.,"Chief of Police In Raid - Removes Objectionable Picture Machines", Oregonian (March 7, 1908), sec. 1 p. 9., "Indecent Photos Shown", Oregonian (March 10, 1908), sec. 1 p. 16., Portland City Directory 1909, p. 861. 11. Ibid. 
12. Ibid.

13. "Views Not Objectionable", Oregonian (March 11, 1908), sec. 1 p. 9., "The Children Free", Oregonian (March 12, 1908), sec. 1 p. 12., "Chorus Girls In Lingerie", Oregon Journal (March 10, 1908), sec. 1 p. 6., "Picture Men Bound Over To Grand Jury", Oregon Journal (March 17, 1908), sec. 1 p. 6., Advertisement - Unique Saloon, Oregonian (August 23, 1908), sec. 4 p. 3.,

"Arcade Owner Freed", Oregonian (April 9, 1909), sec. I p. 11.

14. "Picture Show Men In Trouble", Oregonian (March 1, 1910), sec. 1 p. 4.

15. "Like Moving Picture Plot", Oregonian (March 12, 1909 ), sec. 1 p. 1.

16. "Lives Lost In China", Oregonian (January 9, 1908), sec. 1 p. 11., "Hundred Die By Fire or In Panic", Oregonian (January 14, 1908), sec. 1 p. 1., "Another Moving Picture Panic", Oregonian (January 17, 1908), sec. I p. 7., "Picture Show Takes Fire", Oregonian (July 19, 1908), sec. 1 p. 7., "Fire At Theater Came At Right Time", Oregon Journal (January 5, 1908), sec. 1 p. 3., "Moving Picture Films Catch Fire", Oregon Journal (September 12, 1908), sec. 1 p. 2., "Theater Burned; Nearly 300 Dead", Oregonian (February 16, 1909), sec. 1 p. 1., "Films start Bad Blaze", Oregonian (March 21, 1909), sec. 1 p. 3., "Moving Pictures Burned", Oregonian (March 23, 1909), sec. 1 p. 11., "Nickelodeon Fire Fatal To 
Editor", Oregonian (May 3, 1909), sec. 1 p. 1., "Picture Film Explodes", oreqonian (June 26, 1909), sec. 1 p. 9., "Fire Destroys Theater", Oregonian (February 19, 1910), sec. 1 p. 2., "Real Fire On Canvas", Oregonian (December 11, 1910), sec. 1 p. 1 .

17. Sanborn Map of Portland (corrected to 1908).," Calls Theater Fire Trap", Oreqonian (January 29, 1909), sec. 1 p. 9.

18. "Total Dead 170 At Boyertown", Oregonian (January 5, 1908), sec. 1 p. 1., "Portland Theaters Safe", Oregonian (January 15, 1908), sec. 1 p. 10., "Passion Play Running", Oregonian (January 5, 1908), sec. 1 p. 10.

19. "Asks Firemen To Protect Theaters", Oreqonian (March 14, 1908), sec. 1 p. 10., "Put Firemen In Theaters", Oregonian (April 14, 1908), sec. 1 p. 10., "Fight Over Permit, Power", Oregonian (June 20, 1908), sec. 1 p. 6., "Frame Theaters May Have To Go", Oregonian (July 2, 1908), sec. 1 p. 11.,"Calls Theater Fire Trap", Oregonian (January 29, 1909), sec. 1 p. 9., "Frame Theater's End In Sight", Oregonian (June 4, 1909), sec. 1 p. 12., "Two Years Given", Oregonian (June 12, 1909), sec. 1 p. 18., "Ban On Theater May Be Raised", Oregonian (July 3, 1909), sec. 1 p. 14. 
CHAPTER III

MARKETING INNOVATION AND THE CAMPAIGN FOR EXPANDED PATRONAGE, 1910-1915

Portland local entrepreneurs established the first large-scale motion picture theater operations in 1910. The handful of downtown theaters they constructed and operated differed from the earlier nickelodeons through their use of more sophisticated marketing reflective of the industry's development. By 1915, film theaters had overcome negative reputations and were attracting attendance by Portland's more refined theater audiences. An essential factor in this change were industry advances born of intense competition.

Although the Motion Picture Patents Company had sought to monopolize film production and distribution, its efforts proved incomplete. Several small production companies successfully fought the MPPC for the right to conduct business. The ranks of these independents were augmented when MPPC formed the General Film Company in 1910 as the sole national distributor of its products.

In Portland, the Peoples Amusement Company followed s. Morton Cohn's precedent by affiliation with its own film exchange. In addition to his theaters, cohn contributed the 
Amalgamated Film Exchange to the newly formed PAC. Originally formed as the Morton Film Exchange, it had been forced into business with the MPPC, becoming the MortonEdison Film Exchange late in 1909. It changed its name to Amalgamated when it joined the PAC. ${ }^{1}$

Less than a year later, Amalgamated was consumed by General Film. Although the exchange paid the Trust a licensing fee, MPPC soon found this arrangement inadequate. General Film made overtures to buy out Amalgamated but Melvin G. Winstock, Amalgamated's general manager, felt the offer insulting and refused. According to Winstock, General Film then threatened to revoke Amalgamated's license and terminate its supplies. The manager accused General Film of attempting to smear his reputation when he stood firm. Although his partners never believed these unspecified allegations, the pressure panicked them and they gave in. General Film bought Amalgamated against Winstock's wishes sometime in the Fall of 1910. Taking over Amalgamated's 4th Street location, it named Harley Stevens, Jr., Amalgamated's manager, as its own local representative. Winstock responded that the selling price was unreasonably low and that General Film's compensation had come only grudgingly and tardily.' The PAC dealt exclusively with General Film until June 1912, when it saw an opportunity to draw films from a wider range of companies. General Film's rough treatment was not forgotten. That summer the federal government filed suit 
against MPPC as an illegal trust and sought to compel its dissolution. Once winstock was convinced that the federal government's suit was solid and credible, he moved to break away from the company. D. Solis Cohen's partner, Alexander Bernstein, went to New York in June and arranged assurances of supplies and business from independent film companies. In July 1912, Portland business operations with interests in the PAC formed the Film Supply Company of oregon as the amusement firm's exclusive supplier and usurped General Film's role. Two years later, movie mogul Carl Laemmle acquired Film Supply and turned it into a Universal distributor. ${ }^{3}$

Film Supply Company of Oregon's first president was Sigmund sichel, a local merchant who came from Germany to Portland in 1873. After humble beginnings as a clerk, he established Sig Sichel \& Company, a cigar and tobacco paraphernalia retail business.A prominent civic booster, sichel served terms as a state senator, police commissioner, and on Mayor Joseph Simon's municipal executive board. He left his position with Film Supply Company in $1913 .^{4}$

Arnold I. Blitz, who first appeared in Portland as vice president of Fred Rothchild's newly formed Portland Brewing Company in 1911, succeeded Sichel. By 1913 he was also president of the brewery and ran a saloon. Blitz remained president until Film supply came under new ownership in $1914 .^{5}$ 
Laemmle, a former Milwaukee exchange owner, was one of the earliest independent producers to create a national string of distribution outlets to counter General Film. In 1909, Laemmle founded the Independent Motion Picture Company (IMP) and established a number of exchanges to distribute his films and those of other independent producers. The following year, Laemmle's Portland exchange became distributor for Motion Picture Distribution and Sales Company's films. Laemmle's Portland exchange was the first local independent competitor to General Film. The Motion Picture Distribution and Sales Company held the original companies comprising Universal, which was formed in June 1912 as a distribution company. Several firms initially distributing through Laemmle's first enterprise broke away at this time and formed their own separate independent distribution company, the Mutual Film Corporation, which established Portland's Pacific Mutual Film Company in $1913 .^{6}$

In the next few years, fragmentation continued as more and more national distributorships were formed, each with its own group of film producing companies. Firms such as Universal, Metro, Fox, and Paramount eventually molded their separate parts into large corporations that both produced and distributed their own products. Metro, Universal and Warners established their own specific distribution outlets in Portland by 1916, while Fox and Paramount films were 
distributed through exchanges less explicitly titled. Among the short-lived distribution companies established in Portland were Alco and Eclectic.?

As competition with the independents took its toll after 1912, fragmentation also occurred within the Film Trust. In 1914, Pathe broke from General Film, formed its own distribution company, added some attendant film producing companies, and established an exchange in Portland the next year. Four of the Patents Company's producers set up a short-lived distribution arrangement for themselves in 1915. Known as VLSE, the network served Vitagraph, Lubin, Selig, and Edison. Another arrangement in the same vein was created through Kleine-Edison, which distributed its own products. ${ }^{8}$

More than just a logistical battle for turf rights, independent distribution inspired the growth of motion picture companies with new ideas about the form that film entertainment should take. Lary May has suggested that ideas implemented by the independent producers' productions and promotions largely facilitated acquisition of a mass middleclass audience. A large proportion of the independent producers came from the ranks of nickelodeon operators, entrepreneurs who had a better feel for audience desires and an obvious history of trying to attract higher class audiences. MPPC, on the other hand, had experienced success with its films up to 1910 by attracting a predominantly 
immigrant and working class audience. The innovations of the independents initially were not matched by MPPC. When they proved successful, the Trust lost its industry dominance.9

By 1910, MPPC films averaged two reels and lasted about twenty minutes. Until they observed the positive reception to six-to-nine reel epics imported from Italy, independent producers did the same. Since their length varied so much from the regular nickelodeon format and since their larger budgets required greater audiences and higher prices, the first long films shown in the United States usually appeared in spacious stage theaters. 'Dante's Inferno', the first of these epics to appear in Portland, opened at the Star Theater, a motion picture venue, in October 1911. 'Quo Vadis', a nine-reel film which debuted at the Heilig theater in October 1913, was more typical of the early full feature presentations. Playing to admission prices ranging from twenty five to seventy five cents, the film ran successfully for a full week. It was followed by another Italian saga, 'Cabiria', which also opened at the Heilig in August 1914 and played with equal success at comparable, nonnickelodeon, prices. ${ }^{10}$

By 1913, exhibitions of long features convinced independent producers that films could attract the higherpaying audiences who regularly attended stage plays. Lary May suggests that the increased realism and story definition of longer productions contributed to their appeal because 
they approximated dramatic stage entertainment. After 1912, longer film production was one goal of the independents that subsequently became an industry norm. ${ }^{11}$

The star system, introduced and used to advantage by the independents, was another aspect of motion picture development that increased film's appeal to the higher class theater audiences after 1910. Although MPPC refused to admit innovations that might increase costs and reduce profits, Carl Laemmle believed stars would help his company. Laemmle hired Florence Lawrence away from Biograph in 1910 and publicized her as the "Imp Girl". By doing so, he initiated the identification of all primary actors in film productions and changed the industry forever. ${ }^{12}$

The arrival of motion picture stars served two purposes in raising the general conception of film entertainment. Its first influence was to help eradicate the reputation of anonymity and uniformity of motion pictures. Naming a star helped to distinguish a film and a company from a group of other films. It also indicated to fans of one actor or another a particular film's desirability. Portland use of film actors' names in promoting films did not begin until 1911. The first local newspaper notice of a movie star aimed directly at stage theater audiences. In November 1911, the Arcade Theater advertised the film 'Shipwrecked' by noting that it starred Sydney Ayres, formerly a star with Portland's Baker Stock company. Another notice for a 
Biograph film subsequently described the appearance of Dorothy Bernard, another ex-Baker stock player. The creation of the motion picture star system, like the development of longer films, replicated the form of entertainment seen in legitimate theaters and suggested a continuity between reputable stage and film.

The demarcation line between stage and film stars was made less distinct to Portland audiences when Florence Turner, a Vitagraph star, appeared live on stage at the Peoples Theater in March 1912. Turner performed imitations and demonstrated motion picture acting techniques to her audiences. She was treated as specially as if she were one of America's leading stage actresses and was ostentatiously presented with a bracelet by a local theater executive. ${ }^{13}$

Turner's visit was made possible at the specific urging of a Portland theater director. The appearance epitomized the promotional connection common in the minds of both the independent film producers and Portland's own motion picture exhibitors. While most local exhibitors did not become producers, themselves, their backgrounds as immigrant and Jewish nickelodeon entrepreneurs were similar to the early film producers. National independent makers of movies found complementary minds in the Portland amusement companies formed after 1909.14

S. Morton Cohn's Peoples Amusement Company (PAC) took form in 1910. It was capitalized at $\$ 400,000$ and controlled 
fourteen motion picture-showing theaters in Oregon, Washington and Idaho. Frederick H. Rothchild was the PAC's president through February 14, 1915. Frederick's brother, Samuel M. Rothchild, had become president of the A. P. Hotaling liquor wholesale business by 1893. The Rothchilds were from Louisville, Kentucky, and came to Oregon by way of California. When he arrived in Portland in 1893, Frederick became his brother's vice president. They took over the company in 1895, renaming it Rothchild Brothers. Based at 20-26 First Street North, they were prosperous enough by 1910 to have constructed the Rothchild building at the southwest corner of Washington and 4 th. The PAC's first offices were located on the fifth floor of the Rothchild building at $513 .{ }^{15}$

David Solis Cohen, another of PAC's founders, played a minimally active public role as PAC's secretary from 1910 through 1915 while the PAC's other two founding directors, Mr. A. Berg and Dr. Holt C. Wilson, were all but invisible in their company activities. Although D. Solis Cohen wrote a musical, 'Esther', produced on stage at Portland's Metropolitan Theatre in 1880, he lacked an extensive show business background. Born in Philadelphia in 1852, he came to Portland via Oakland, California. A connection between the wholesaler he worked for in Oakland and Portland led him to Oregon as a resident and proprietor of the Golden Rule Bazaar by 1880 . He augmented this wholesale business at 
Front and Ankeny with an active role in Portland's civic and Jewish community. He was admitted to the bar in 1897 and thereafter was partner in a law firm with Alexander Bernstein. During the 1890 s Cohen was also a politically active Republican, becoming close with Joseph Simon, Oregon's Republican Party leader. In 1898 he was appointed to Portland's Police Commission where he served until 1902. Between 1900 and 1910 Cohen continued his prominent civic activities. During this period he joined $\mathrm{S}$. Morton Cohn, Ignatz Lowengart, and Alexander Bernstein in the Associated Investment Company, brokering Portland real estate. ${ }^{16}$

other PAC founders included banker Edward Shainwald. After establishing himself as president of the First National Bank in Weiser, Idaho, Shainwald moved to Portland in 1910. He was the PAC's first treasurer, a position he held through 1915. Shainwald was an active member of the local Jewish community and served many civic causes. ${ }^{17}$

Louis B. Christ left his position as treasurer of the Portland (vaudeville) Orpheum to help found the PAC. He began work in the Portland entertainment business during the $1890 \mathrm{~s}$ as an usher in Cordray's Third Street Theater and for George Baker. Christ became manager of the Star Theater in September 1915 and continued after the theater changed its name to the Pickford Theater. ${ }^{18}$

The Star was one of seven theaters the PAC initially ran in Portland. In addition to the star and Arcade, PAC 
acquired the on Joy theater on Morrison and in May 1910 opened its fourth facility, the Odeon, on 5th street. At the Odeon's debut, the above mentioned theaters received prominent advertising as "The Big Four" and were heralded as outlets for first-run films exclusive to Portland.

The Big Four lasted as such for less than a year. The Odeon theater closed in April 1911 when it lost its lease. After the PAC opened the Peoples theater late in 1911, emphasis on first-run films in premier theaters was increasingly limited to the Star and the Peoples. Both theaters remained the prestigious symbols of the PAC through 1915, although the Star was renamed the Pickford in honor of Mary Pickford's immense popularity. The other two of the original four continued with decreasing fanfare into 1914, when the Arcade's lease was allowed to expire and the Oh Joy closed. ${ }^{19}$

Beginning with the Palace and Orpheum, the PAC expanded to run fourteen second-run film houses in Portland by the end of 1911. While the Bijou theater on 7 th street and the Oh Joy were acquired from Gustave A. Metzger, Solomon N. Baum sold the Casino. Although PAC discarded all these theaters by 1914, Baum and Metzger advanced their entertainment business careers through various positions with the amusement company. ${ }^{20}$

Gus Metzger initially worked as a jeweler in Metzger and Co. from about 1906 to 1908. He then opened a 
nickelodeon and ran two or three others for absentee owners until he joined PAC. After the PAC's Film Supply Company of Oregon was sold, Metzger remained with the exchange as a Universal employee. ${ }^{21}$

Solomon Baum had been a Portland resident since the early 1890s. Born in Albany, Oregon, he first worked in Portland in the Baum and Brandes catering business. During the latter part of the decade he worked in a relative's restaurant and briefly ran his own restaurant. From 1899 to 1902, Baum worked as a clerk at the Blumauer-Frank Drug Co. and then as a salesman for two different box-making companies before opening his theater, probably in 1908. In return for the Casino, he assumed a role in the PAC's founding, working as superintendent and later assistant manager of the PAC until his resignation on June 19, 1915. Baum had written successful film scenarios and left the PAC with an offer to become scenario editor for "a large California film company." 22

The PAC's theatrical empire extended beyond downtown Portland into various cities throughout oregon, Washington and Idaho. Theaters away from Portland's downtown were never as ambitious because they served as neighborhood houses for smaller communities. Just across the willamette River, PAC established the Tivoli on Williams Avenue in 1910 and the Crystal on killingsworth two years later. The PAC also built the Sunnyside theater on Belmont and intended to build 
another venue in St. Johns in 1913. While the PAC continued expansion in Portland, its Oregon properties included the star and Orpheum in La Grande, the Grand in The Dalles, the Star in Astoria, and the star in Medford. In Washington, the PAC ran the Lyceum and Alaska theaters in Seattle. In Idaho, it owned Caldwell's Star Theater. ${ }^{23}$

PAC general manager Melvin G. Winstock strenuously sought to expand the syndicate's interests. The most spectacular development came in 1911 when the company determined to build a theater designed exclusively for the exhibition of movies - the first of its kind in Portland. What winstock modestly called "the most ambitious motion picture theater enterprise ever launched in the United States'" was built on the former site of Portland's venerable Arlington Club, a lot on the northwest corner of Park and Alder. While originally scheduled to open in October of 1911, construction delays postponed the Peoples Theater's public debut until November. ${ }^{24}$

The James Amusement Company provided the PAC's first competitor in the race to win Portland's more refined audiences. Established by Edwin F. James in July 1910, the company soon opened the Majestic Theater at 5 th and Washington. In March of the next year, James leased a building on the northeast corner of Park and Washington, renovated it and opened it in June. This new theater retained the name "Majestic" and continued under James's 
management through 1915. Developing similarly to the PAC, the James Amusement Company conducted two smaller second-run theaters, the Princess and the Savoy, for a short period beginning in 1911. Like the PAC, the company divested itself of second-run theaters by 1913.25

A Seattle real estate broker, Edwin James came to Portland in July 1910. He leased the Olds, Wortman and King building in August and opened it as the Majestic after only nine days of refitting. In March 1911, he leased the Brooke estate building at $3531 / 2$ washington. After $\$ 62,000$ in renovations, the new Majestic opened just after the Rose Festival in June. ${ }^{26}$

The Globe Theater was another facility that competed for upscale audiences in an increasingly archaic motion picture theater location. Construction of new and prestigious theaters was a keystone in the trend toward redefining motion picture audiences. Yet the Globe, which opened in September 1912, was located on the south side of Washington Street between 10 th and 11 th in a pre-existing structure. Of all the ambitious first-run theaters that debuted during the 1910s, the Globe was the first to retreat from the fight. It disappeared from the first-run competition by the end of $1915 .{ }^{27}$

I. Leeser Cohen's experience exhibiting motion pictures dated to his work with the Vitascope at Cordray's Third Street theater in 1896. Cohen had been a Portland resident 
since the early 1890 s and by 1893 managed the Golden Rule Bazaar. By 1895 D. Solis Cohen had severed his partnership with Mr. Davis of San Francisco and ran the Golden Rule Bazaar as a partnership with his brother who took over the business with William Goldman in 1898 when D. Solis Cohen had begun his law practice. By 1899 he worked as clerk and then department manager at the Blumauer-Frank Drug Co. until 1906 when he ran the oregon Photo stock Co. selling photographic supplies and apparatus; he managed the same company after it became the Blumauer Photo supply Co. in 1908 while augmenting his income as a jeweler until the Globe Theatre Company was formed in $1912 .{ }^{28}$

A. L. Levy had worked with S. Morton Cohn in 1909 and 1910 in the Amalgamated Film Exchange. He remained president of the Globe company after it was reorganized as the Portland Amusement Company in 1914. After the reconstitution Bernstein left and I. Leeser Cohen assumed his secretarial position. Harley C. Stevens, Jr., veteran manager of Portland's General Film outlet, joined the company as vice president. ${ }^{29}$

The Columbia, the second Portland theater built expressly for motion picture exhibition and higher class audiences, opened on the corner of 6 th and Washington in June 1913. It was constructed by walter F. Foster and George W. Kleiser, partners dedicated primarily to the advertising business, who had branched out into theater ownership in 
various large West Coast cities and decided to build a facility in Portland. During Foster \& Kleiser's tenure in Portland, the Sunset Theater, another renovated facility, opened and worked to attract higher class audiences. The Sunset's debut resulted from the expiration of a lease for the Arcade Theater in April 1914. The Sunset replaced the former venue between July and the end of $1915 .{ }^{30}$

Shortly before the Arcade changed hands, Melvin Winstock began the National Amusement Company, a syndicate that built Portland's third originally conceived motion picture theater. By the end of March 1914, the energetic Winstock announced the leasing of a lot on the south side of Stark near Park on which would stand the National Theater. Complications with building permits and other technicalities delayed construction and the National Theater's opening until October. Moreover, Winstock did not remain with the National very long after its opening. He resigned in July 1915, stating his desire to take a vacation and then "devote his time to producing motion pictures." 31

John S. Beall assumed the role of managing director in July 1915 and appointed Mr. M. M. Rouse, a Los Angeles Paramount employee, general manager and resident manager of the National. By September, the National Amusement Company was taken over by receivers, and the theater was managed by Orrin E. Goodwin, who remained until October 16, 1915 when George H. Grombacher took over the reorganized firm. The 
National's new managing director was Allen C. Churchill. A. L. Stevens presided over the board of directors including Grombacher, Churchill, J. P. Winter and Stanfield N. Arnold. ${ }^{32}$

George Grombacher worked in real estate in Cleveland until 1905 when he formed a partnership with Frank T. Bailey. Based in Butte, Montana, Grombacher \& Bailey established a chain of nickelodeons, supplying it with their own film exchange. By 1910, their original exchange taken over by General Film, they formed the Independent Western Film Exchange covering a vast northwestern area including Oregon; Grombacher came to Portland in 1912 as general manager for Independent's Portland concerns. In addition to his position with the National Amusement Company by the end of 1915 Grombacher was also president of the Montana Amusement company and a vice-president of the Metro Film Corporation. ${ }^{33}$

Grombacher, Winstock, Cohn, Cohen, James and Jennings all shared backgrounds similar to the men who led the movie industry. Like Carl Laemmle, William Fox, Adolph zukor, and Jesse Lasky, Portland's first motion picture exhibitors were of either Jewish or non Anglo-Saxon immigrant background. Both groups had previously been employed in a variety of mercantile ventures and had a history of seeking advancement through new and non-exclusive opportunities. Development of the movie industry provided just such an example. While some 
ultimately led the industry's production, Portland's entrepreneurs exploited the possibilities of exhibition. The group of Portland theater owners found itself increasingly out of sympathy with the MPPC and supported the PAC's dramatic break with General Film in 1912. At issue was the desire for free choice that underlay the independents' efforts. 
CHAPTER III NOTES

1. Advertisement, Oregonian (February 27, 1910), sec. 4 p. 3., Portland City Directory 1910, p. 1194.

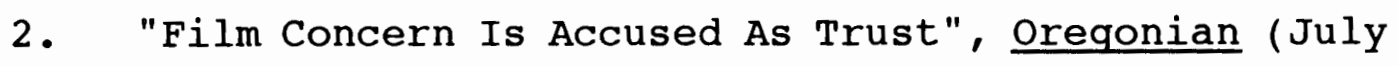

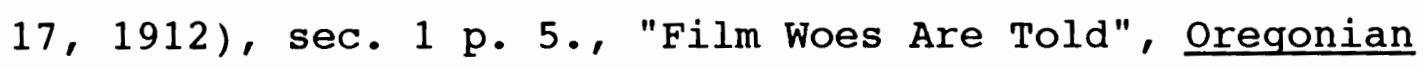
(September 1, 1912), sec. 2 p. 5., Portland City Directory 1910, p. 1062., Portland City Directory 1911, pp. 571, 1371,1833 .

3. "Film Concern Is Accused As Trust", Oregonian (July 17, 1912), sec. 1 p. 5., "Film Woes Are Told", Oregonian (September 1, 1912), sec. 2 p. 5.

4. "Sigmund Sichel Dead At Age of $60 "$, Oregonian (December 11, 1917), sec. 1 p. 14.

5. "Film Concern Is Accused As Trust", "D. S. Cohen States Case", Oregonian (June 29, 1912), sec. 1 p. 12., Portland City Directory 1912, pp. 242,1356., Portland City Directory 1913, p. 449., Portland City Directory 1914, pp. $562,716,996$. , Portland City Directory 1915, pp. 452,831.

6. Hampton, Movies, pp. 26-27,80-82., Sklar, MovieMade, pp. 38-40., Portland City Directory 1910, pp. 656,1463., Portland City Directory 1911, pp. 571,845,1833., Portland City Directory 1912, p. 1866., Portland City Directory 1913, pp. 492,721,1585-6., Portland City Directory 1914, pp. 609,865,1107,1728-9., Portland City Directory 1915, pp. $452,494,928,1486-7$. 
7. Hampton, Movies, pp. 80,117-21,132,141., Sklar, Movie-Made, pp. 40-44., Portland City Directory 1915, pp. $142,416,1234,1486$. , Advertisement, Oregonian (November 14, $1915)$, sec 1 . p. 5 .

8. "Four Movie Firms Combine", Oregonian (April 7, 1915), sec. 1 p. 7., "Film Depot Is Proposed", Oregonian (May 22, 1915), sec. 1 p. 8., "Split Reels", Oreqonian (August 29, 1915), sec. 4 p. 5.

9. Hampton, Movies, pp. 89-90., Sklar, Movie-Made, pp. 41-42,44,46., Lary May, Screening Out The Past (Chicago, 1980), pp. 169-71.

10. Hampton, Movies, pp. 104-108., Advertisement, Oregonian (October 8, 1911), sec. 4 p. 3., Advertisement, Oregonian (September 28, 1913), sec. 4 p. 3., "Quo Vadis Coming", Oregonian (September 28, 1913), sec. 4 p. 2., Advertisement, Oregonian (October 6, 1913), sec. 1 p. 4., Advertisement, Oregonian (August 2, 1914), sec. 4 p. 3., "Olden Era Filmed", Oregonian (August 10, 1914), sec. 1 p. 14.

11. Hampton, Movies; pp. 104-106.

12. Hampton, Movies, pp. 83-89., Sklar, Movie-Made, pp. 40., May, Screening, p. 177.

13. Hampton, Movies, pp. 83-87., Advertisement, Oregonian (September 24, 1911), sec. 4 p. 3., Advertisement, Oregonian (November 29, 1911), sec. 1 p. 14., "Film Producer Here", Oregonian (February 4, 1912), sec. 1 p. 14., "Photo Play Star Here", Oregonian (March 14, 1912), sec. 1 p. 4., Advertisement, Oregonian (March 17, 1912), sec. 4 p. 
3., "Film Shows Junketers", Oregonian (March 24, 1912), sec. 1 p. 4 .

14. May, Screening, pp. 169-72.

15. Portland City Directory 1892 , p. 531., Portland City Directory 1893, p. 776., Portland City Directory 1894, p. 669., Portland City Directory 1896, p. 685 Portland City Directory 1907-08, p. 1106., Portland City Directory 1909, pp. 413,741, 1057,1067,1631, , Portland City Directory 1910, pp. 579,1519 ., Portland City Directory 1911, pp. 1134,1244 ., Portland City Directory 1912, pp. 729,1340, , Portland City Directory 1913, p. 1132 Portland City Directory 1914, pp. $728,1130,1282$, Portland City Directory 1915, pp. $322,949,1085$. "Picture Theaters Pass To Syndicate", Oregon Journal (February 16, 1910), sec. 1 p. 10., Advertisement Peoples, Oregonian, (May 11, 1910), sec. 1 p. 15., Advertisement - Peoples, Oregonian (June 5, 1910), sec. 4 p. 3., "Parole Policy In Film", Oregonian (February 11, 1912), sec. 1 p. 13., "Peoples Company Meets", Oregonian (February 15, 1912), sec. 1 p. 4., "Portland To Get $\$ 100,000$ Theater", Oregonian (February 15, 1914), sec. 1 p. 15., "J. F. Cordray Picked", Oreqonian (October 15, 1914), sec. 1 p. 11., "Theater Company Elects - Max Hirsch Is President of Peoples Amusement Company", Oregonian (February 19, 1915), sec. 1 p. 9., "Mr. Cordray Quits", Oregonian (May 13, 1915), sec. 1 p. 18 . The Peoples Amusement Company took form on February 14, 1910. 
16. William M. Kramer, "David Solis-Cohen of Portland: Patriot, Pietist, Litterateur And Lawyer", Western States Jewish Historical Quarterly (January 1982), pp.142,138, $162,163 .$, E. Kimbark MacColl, The Shaping of A City: Business And Politics In Portland, Oregon 1885-1915 (Portland, 1976), pp. $194,201,213,237,253$, "Heilig To Be Reopened", Oregonian (August 20, 1909), sec. 1 p. 9.

17. "Movie Magnates - No. 2", Oregonian (December 26, 1915), sec. 4 p. 6., "Oldest Elk Dies At 93", Oregonian (September 25,1947 ), sec. 1 p. 13 .

18. "Theater Now 'Pickford'", Oregonian (October 27, 1915), sec. 1 p. 11., "Movie Magnates - No. 2", Oregonian (December 26, 1915), sec. 4 p. 6 .

19. "National Theater Sold", Oregonian (May 9, 1910), sec. 1 p. 7. "Arcade Theater Is 'Dark' - Movie House To Reopen When Improvements Are Made", Oregonian (April 15, 1914 ), sec. 1 p. 4., "Theater Now "Pickford" ", Oregonian (October 27, 1915), sec. 1 p. 11., Advertisement, Oregonian (April 30, 1911), sec. 4 p. 3., Portland City Directory 1912, p. 1933., Portland City Directory 1913, p. 917.

20. "National Theater Sold", Oregonian (May 9, 1910), sec. 1 p. 7 .

21. Portland City Directory 1907-08, p. 903., Portland City Directory 1909, p. 961., Portland City Directory 1910, p. 769., Portland City Directory 1911, p. 990., Portland City Directory 1912, p. 1029., Portland City Directory 1915, p. 
831 .

22. "Hippodrome Is Reopened", Oregonian (August 31, 1911), sec. 1 p. 16., "Theater Man Resigns", Oregonian (June 19, 1915), sec. 1 p. 9., "Solomon Baum Is Dead", Oreqonian (March 8, 1921), sec. 1 p. 22., Portland City Directory 1896, p. 158., Portland City Directory 1898 , p. 157., Portland City Directory 1901-02, p. 136., Portland City Directory 1902, p. 176., Portland City Directory 1905, p. 198., Portland City Directory 1907-08, p. 263,903., Portland City Directory 1909, pp. 272,961., Portland City Directory 1910, pp. 167,769., Portland City Directory 1911, pp. 201,990., Portland City Directory 1912, pp. 203,1029., Portland City Directory 1913, pp. 449,932., Portland City Directory 1914, pp. pp. 562,996., Portland City Directory 1915, pp. 293,452, 831,931 .

23. "New Pictures To Be Shown", Oregonian (October 2, 1910), sec. 4 p. 3., "New Theatre Projected", Oregonian (March 2, 1910), sec. 1 p. 6., "New Theater Is Rushed", Oregonian (August 6, 1911), sec. 3 p. 10., "St. Johns To Get Theater", Oregonian (February 9, 1913), sec. 1 p. 11., Portland City Directory 1911, pp. 198,602., Portland City Directory 1914, p. 1369., Portland City Directory 1915, p. 1160., "Picture Theaters Pass To Syndicate", Oregon Journal (February 16, 1910), sec. 1 page 10., "New Theater Obtained", Oregonian (February 7, 1911), sec. 1 p. 9., "New Theater Rushed", Oregonian (August 6, 1911), sec. 3 p. 10., 
"New Theater In Medford", Oreqonian (August 28, 1911), sec. 1 p. 5 .

24. "Theater To Build", Oregonian (May 4, 1911), sec. 1 p. 11., "Theater Plan New", oreqonian (July 9, 1911), sec. 4 p. 7., "New Peoples Theater Built And Completed In One Hundred Days", Oreqonian (October 29, 1911), sec. 2 p. 6., "New Film Show Ready", Oreqonian (November 1, 1911), sec. 1 p. 11., "New Theater Opens", Oreqonian (November 2, 1911), sec. 1 p. 4., "New Theater Is Rushed", Oregonian, (August 6, 1911), sec. 3 p. 10 .

25. "Theatre Site Leased", Oregonian (March 12, 1911), sec. 1 p. 3., "Majestic Theatre", Oregonian (June 15, 1911), sec. 1 p. 15., "Theater Is Not Closed", Oregonian (May 3, 1911), sec. 1 p. 11 .

26. Ibid.

27. "Bunny Suicides", Oregonian (September 14, 1912), sec. 1 p. 11., Advertisement - Globe, Oregonian (September 14, 1912), sec. 1 p. 12., "Globe Theater Opens", Oregonian (September 15, 1912), sec. 1 p. 4.

28. Kramer, "David Solis-Cohen of Portland", pp. $140,148,150,163$., Portland City Directory 1893, p. 317., Portland City Directory 1894, p. 260., Portland City Directory 1895, p. 232., Portland City Directory 1896, p. 220., Portland City Directory 1898, p. 216., Portland City Directory 18991900, p. 228., Portland City Directory 1901-02, p. 213., Portland City Directory 1903, p. 213., Portland City Directory 
p. 413., Portland City Directory 1910, p. 125., Portland City Directory 1914, pp. $287,418,562,625,740,972$.

29. Portland City Directory 1914, pp. $287,418,562,625$, 740,972., "Globe Theater Opens", Oregonian (September 15, $1912)$, sec. 1 p. 4 .

30. "Fine Theater To Open", Oreqonian (June 15, 1913), sec. 4 p. 8., "Theater Opens Tonight", Oreqonian (June 18, 1913), sec. 1 p. 18., "Columbia Theater Host To Thousands", Oregonian (June 19.1913), sec. 1 p. 4., "Light Theater Is Boast", Oregonian (July 26, 1914), sec. 1 p. 4., "Sunset Soon To Open", Oregonian (July 30, 1914), sec. 1 p. 9., "Newest Movie Viewed", Oregonian (July 31, 1914), sec. 1 p. 5., "Columbia Here Leased", Oregonian (June 30.1915), sec. 1 p. 5., "Manager of Columbia Long Experienced In Work", Oregonian (January 2, 1916), sec. 4 p. 4.

31. "Portland To Get $\$ 100,000$ Theater", Oregonian (February 15, 1914), sec. 1 p. 15., "Theater Company Formed", Oreqonian (March 11, 1914), sec. 1 p. 13., "Photo Play Notes", Oreqonian (March 22, 1914), sec. 4 p. 3., "Another Theater Is To Rise At Once", Oregonian (March 29, 1914), sec. 4 p. 16., "New Theater Assured", Oregonian (April 19, 1914 ), sec. 1 p. 9., "National Theater", Oreqonian (April 26, 1914), sec. 4 p. 11.," Theaters Feature In Building Niews" (sic), Oregonian (June 28, 1914), sec. 4 p. 10.

32. "Movie Men Roused By Women Censor", Oregonian August 7, 1915), sec. 1 p. 4., "Kiss Charged To Janitor", 
Oreqonian (October 14, 1915), sec. 1 p. 17., "National Is Reorganized", Oregonian (October 17, 1915), sec. 1 p. 2., "Activities of Pioneer Movie Man Cover Wide Range", Oregonian (February 6, 1916), sec. 4 p. 4., "National Theater Manager Knows Game In All Its Branches", Oreqonian (January 9, 1916), sec. 4 p. 4., Portland City Directory 1910, pp. 169,280, 298,389., Portland City Directory 1911, pp. 204,348,373,494., Portland City Directory 1913, pp. 155,325,636., Portland City Directory 1914, pp. 233,770., Portland City Directory 1915, pp. $142,165,308,329,429,986 .$, Portland City Directory $\underline{1916}$, p. 165 .

33. "National Is Reorganized", Oregonian (October 17, 1915), sec. 1 p. 2., "Activities of Pioneer Movie Man Cover Wide Range", Oregonian (February 6, 1916), sec. 4 p. 4., "National Theater Manager Knows Game In All Its Branches", Oregonian (January 9, 1916), sec. 4 p. 4., Portland City Directory 1910 , pp. $169,280,298,389 .$, Portland City Directory 1911, pp. 204,348,373,494., Portland City Directory 1913, pp. $155,325,636$. , Portland City Directory 1914, pp. 233,770., Portland City Directory 1915, pp. 142,165,308,329,429,986., Portland City Directory 1916, p. 165. 
CHAPTER IV

THE LEGITIMIZATION OF THE MOTION PICTURE ENVIRONMENT, $1910-1915$

The evolution of distribution companies was merely one aspect of the rapid development of a film industry increasingly dominated by middle class patrons. In conjunction with the rise of independent producers and their incessant drive to gain a larger and higher class audience, Portland's first run motion picture theater companies worked at acquiring local reputations for civic responsibility and elite appeal. After september 1913, specific theatrical promotions and activities were augmented by formation of the Association of Portland Movie Theater Managers. In December 1913, the APMTM was absorbed as chapter \#40 in the national Motion Picture Exhibitors' League. Its representatives continued to speak in municipal and social forums for the general benefit of Portland's motion picture theaters. ${ }^{1}$

The character of promotions, building renovations, and public pronouncements initiated by Portland's downtown first-run theater managers exemplified the nation-wide drive by both independent producers and exhibitors toward a higher class audience. Many of these activities involved emulations 
of legitimate theater standards, many were implicit responses to general social concerns about the hazards inherent in motion picture theaters, and some came about as mere compliance with the evolving municipal building codes as they applied to theaters.

The ordinance prohibiting the use of frame buildings for theaters, for example, became effective in Portland in April 1912 after years of contention and delay. The safety code equated legitimate and motion picture theaters. Compliance with safety building codes in regard to fireproofing and emergency exits frequently received notice when new theaters were constructed. Code compliance gave motion picture theaters further opportunity to advance their reputations beyond the image of makeshift, dirty firetraps. More important, requirements for asbestos-lined and easily sealed projection booths helped avert disaster at the Star Theater in 1913. On a Monday night in September, with four hundred persons in attendance, film in the projector caught fire but was limited to the projection booth and extinguished. Other smaller theaters in the region also experienced fires of varying devastation. Despite the code's existence, however, Portland's fire marshal still found several types of fire hazards commonly unremedied in many of the downtown theaters. Still, audience safety in theaters that used extremely inflammable materials increased greatly between 1910 and 1915, as did the public image of safety. ${ }^{2}$ 
While theater owners willingly complied with marketable safety ordinances, they worked much more zealously at publicized activities meant to create a special atmosphere for their patrons. Consistent with the independent producers' consumer-orientation was development of theater techniques designed to provide patrons with a feeling of uniqueness in an urban environment increasingly impersonal and anonymous. Much of this was achieved subtly through lavish, non-machine-age interior decoration designed to make audiences feel as if they were at a time and place apart from their modern city. This urge was regularly addressed by downtown theater owners who often redecorated and renovated their theaters during this period. The PAC renovated the Star Theater twice and the Peoples once, the Majestic was redecorated on two occasions, and the Arcade was thoroughly redone before it opened as the sunset. Each renovation sought to increase a theater's palatability to its patrons. Desirability, convenience, and women's opinions were emphasized when aesthetic particulars about a theater's interior redecoration were cited. ${ }^{3}$

Within the comfortable and plush theaters, patrons were served with courtesy and attentiveness in an effort to create the impression of prestige and self-importance. Lary May notes that it became standard to have young and courteous ushers answerable to any patron's question or discomfort. While there is not much direct evidence beyond 
the Sunset Theater presenting its customers with welldressed young women ushers, there was a clear intention in all of Portland's first-run movie theaters to provide courteous care and ensure an environment free from the stress of city life. ${ }^{4}$

The star Theater designed a promotion which not only encouraged a family audience but also emphasized the particular nature and qualities of its patrons. For a few weeks in 1912 , it held a baby contest in which entrants came to the theater to have their babies filmed. The movies then were shown to the Star's regular audiences, which voted for the "most beautiful" baby. Parents were given the section of film holding the image of their child, encouraging family and parental pride, reinforcing the notion of an audience's individual identities, and at the same time creating a family environment at the theater. ${ }^{5}$

The period's family environment concept was directed more at neutralizing the threat of movie content than at attracting a large audience of women and children. Seeking more affluent audiences, exhibitors emulated the physical aspects of legitimate theaters but also sought an aura of acceptability not found in the older facilities. As new motion picture theaters appeared in Portland, the combination of tradition and change was exemplified in seating and theater names. With the exception of the sunset, which inherited a building with limited space, none of the 
major first-run motion picture theaters in Portland had a capacity below eight hundred. The Heilig, despite its many -locations, had always averaged seating of a thousand or more, including box seating. It was no coincidence that when the Peoples Theater was built it had a capacity of twelve hundred. The post-1911 Majestic held twelve hundred, the Globe eight hundred, the Columbia about a thousand, and the National two thousand. Motion picture theaters were implying a similarity to legitimate theaters through their size and capacity. ${ }^{6}$

While the capacities of movie facilities echoed legitimate theaters, there were customs of seating in motion picture venues that beckoned to the traditionally refined audiences and also accommodated persons on the more democratic level. Unlike the segregation of class and sex in legitimate theater seating areas, motion picture halls continued to allow all seating available to men, women, and children. Yet at the same time, most of Portland's downtown motion picture theaters offered exclusive box seating for the upper classes. The only restricted seating in local movie houses occurred along racial lines. Blacks were limited to balcony seating, another emulation of legitimate theaters and a gesture to the intense racial feelings of the 1910 s. $^{7}$

Although the capacities and seating policies of film theaters often aligned with traditional legitimate theater 
standards, imagery associated with movie theaters in Portland developed along national parameters. Theater names, for example, were consistent with the images of escape and reassurance that ushers, theater interiors, and film content supported. Themes of democracy and patriotism were among those which sought to make patrons feel welcome and privileged. They also implied a certain amount of social responsibility on the theater management. Within this context, both the Peoples Theater and the National featured names that served specific purposes. Another type of thematic movie theater definition was based on grandeur and a mimicry of immense scale and opulence. In this regard, both the Majestic and the Globe provided fruitful examples, while the sunset merely offered notions of sentimentality and serenity associated with the calm end of a day. ${ }^{8}$ The concept of comfort and escape was further intertwined with the standards of legitimate theaters through special ornamentation and design. When the National was completed, newspaper accounts noted that its elevators were a first for a motion picture theater and were based on the design of large opera theaters in the East. Exteriors, however, usually supported the developing image of escape and otherworldliness inherent in motion picture theaters. One byproduct of the several renovations occurring in Portland's movie theaters was redesigned entrances with vast arrays of electric lights. In this way motion picture 
theaters maintained the mixed theme of legitimate theater standards and their own images of escape from life in the modern city. ${ }^{9}$

While legitimacy was sought through physical structures, motion picture exhibitors in Portland constantly worked in the community to establish an identity of civic and social responsibility. The idea that films were physically and morally harmful to people, particularly children, continued to plague the industry. It was essential to the companies running the most prestigious movie theaters that they successfully overcome this notion, which they fought through civic activities involving children, education, legislation, and the overall welfare of society.

Portland film entrepreneurs attempted to soothe local anxieties over the effect of movies by aligning themselves with the forces of progressive reform. On two occasions, both in 1912, the PAC campaigned for the spread of urban and penal reforms for Oregon and for the nation. Late in January 1912, the PAC announced exhibition of the film 'City of Boys,' a documentary about a colony established in Charlevoix, Michigan, by Judge Willis Brown for the benefit of homeless and wayward urban boys between the ages of eleven and seventeen. PAC general manager Melvin Winstock invited mayor Harry Albee, Portland officials, and Governor Oswald West to attend a special screening of the film as part of the PAC's active attempts to have such a system 
instituted in Oregon. ${ }^{10}$

Winstock also publicized Oregon state prison reform in a screenplay he sold to the MPPC with Governor West's approval. Through a theatrical narrative, the story illustrated the value of Oregon's newly instituted prison parole system. It was eventually produced by Edison as 'The Convict's Parole' in 1912. Winstock expressed the hope that through its national exposure, the film would encourage other states to adopt Oregon's parole system. ${ }^{11}$

When theaters showed prestigious productions of religious themes, great care was taken to appeal to the local clergy. Ministers of all denominations were invited to special advance screenings of films such as the 'Moses' series or 'The Star of Bethlehem.' Religious endorsements also were sought on occasions when films dealt with public health topics. 'Damaged Goods,' a movie dealing with venereal disease, played at the National in October 1915. Social topics were likewise addressed through films dealing with proper child-rearing, water purification, and a variety of diseases. ${ }^{12}$

Active support of local commercial and promotional groups helped to foster the image of theaters as stable, solid, and traditionally-aligned members of the city and state. Theaters often had contracts with local motion picture cameramen. Others used special film procurement abilities to their advantage by exhibiting footage of the 
"Oregon First" delegation choosing a site for the San Francisco Exposition, the opening of the Celilo canal, scenes of the Columbia River Highway, and portraits of Northwest flora and fauna. Film of trips by local Rosarians, the Ad Club, and the Press Club were shown to the members after their return to Portland. As members of the community, Portland's motion picture theaters also donated use of their screens to local causes as when they displayed slides for a 'City Beautiful' program or a citywide effort to encourage church attendance. ${ }^{13}$

Despite such efforts, criticism of the supposed influence of motion pictures on children never abated. The primary concern of parents and moralists focused on the subject matter of films. A common notion that children imitated crimes they saw on screen was regularly supported by newspaper articles that described juvenile theft, arson, and mayhem. Consequently, parent and school groups in Portland sometimes objected to the construction of motion picture theaters in their neighborhoods as well as the regular entertainment fare presented in local theaters. Concern over theater influence on children was so great that late in 1913 Mayor Albee asked Mrs. Robert H. Tate of the Oregon Congress of Mothers to recommend a committee of scholastic, club, and civic leaders to study Portland's vaudeville and film theaters. The following January, Albee commissioned a group led by William Trufant Foster of Reed 
College to evaluate the status of Portland's vaudeville and film theaters "'to see that the welfare of the children is conserved.'"14

In order to alleviate parental concern, motion picture theaters took special pains to cater to children in a constructive manner. When film of educational value was shown as a regular attraction, young patrons were invited to come at special early Saturday showings. Stories based on classical themes or biographies often met this criteria. Children were encouraged to see 'Julius Caesar,' 'The Last Days of Pompeii,' and Paul Rainey's hunt film at special times and prices. Applied education was promoted through essay contests on film themes. Furthermore, a reciprocal arrangement between the PAC and Portland's library commissioner encouraged the reading of classics when films of those stories were locally exhibited. Melvin winstock sought Mayor Albee's advice before building his new venue. As a newly conceived motion picture theater, the National was built with a basement playroom for children and soon developed a regular Saturday afternoon story hour and giftgiving. Through various promotions and designations, the prestigious downtown motion picture theaters worked to provide a good environment for children.15

Although movie promoters sought to be good citizens, the controversy over filmed versions of boxing matches placed them in direct confrontation with reformers. Concern 
over the crowds attending prizefights led to a 1910 ban prohibiting any exhibition of boxing in oregon. When film of the 1910 James Jeffries-Jack Johnson match became available early the next year, plans were made for a Portland showing despite the state boxing prohibition. Exhibitors argued that film of a boxing match differed from an actual boxing match and thus was not affected by the law. Yet Municipal League members and religious leaders were determined that the law would apply to films as well.16

Exhibitors leased George Baker's Bungalow Theater to show the Jeffries-Johnson fight film early in 1911. Pressed by Municipal League reformers and clergy, police monitored the Bungalow's entrance. Grounds for arrest and prosecution were to be based on a 1903 state statute prohibiting the depiction of a crime in motion pictures. Mayor Joseph Simon and the district attorney's office held that since actual boxing was illegal in Oregon, a boxing film depicted an Oregon crime and was thus illegal. Pressure and threats succeeded, and the film was withdrawn. ${ }^{17}$

Despite the victory for reformers, boxing movies occasionally made it to the screens of downtown theaters in the next one-and-a-half years. Exhibitors maintained that boxing films had public support and were worth fighting for. Yet when the management of the Bijou vaudeville theater and the distributor of a boxing film forced a trial to challenge the oregon law, they were foiled when the prosecution 
applied a new standard which again convicted the exhibitor. Under the terms of the revised Interstate Commerce Act of 1912, interstate transportation of filmed boxing matches was prohibited. Accordingly, the federal statute became the basis for prosecution, and no boxing features subsequently were shown by prestigious downtown exhibitors. ${ }^{18}$

While boxing films attracted considerable public attention, Portland's Board of Censors assumed far greater influence over the exhibition of motion pictures. Introduced at the urging of women's clubs by City Council Member Gay Lombard in March 1911, the censorship bureau began work for a proposed six month trial period. Although Lombard had turned against his own proposal as dictatorial, it was passed and the experiment won Melvin Winstock's praise and promises of cooperation from Portland exhibitors. Movie operators accepted the innovation because of appeal guarantees in which contentious samples of film were to be subjected to a standing jury composed of disinterested citizens whose decision was final. ${ }^{19}$

Like the New York Board of Censors, the Portland entity used advisors from local women's clubs and justified its existence in terms of the moral welfare of children and Anglo-Protestant values of propriety. When the MPPC faced legal and financial failure in 1915, Portland's censorship bureau took on a new importance. But the Board faced a blatant power struggle with Portland's exhibitors when its 
decisions became legal decisions rather than merely advisory. Having built a reputation for social responsibility, exhibitors resented censorship interference in their business, particularly since the National Board's approval seemed an adequate guide for public acceptability.

By 1913, reports began to surface that downtown theater managers were becoming dissatisfied with the Board's opinions and believed that the bureau had become oppressive. Exhibitors were particularly upset that Mayor Albee had appointed the Police Chief as an associated member of the panel with legal ability to confiscate "objectionable" films. Tensions peaked when the mayor openly reproached Portland exhibitors in 1914 for defying the board's rulings on movies. ${ }^{20}$

Reaching the end of his patience the following February, Albee introduced an ordinance to provide the censor board with legal powers and abolish its appeal procedures. Exhibitors protested that their theaters never showed films rejected by the New York Board. Once the Portland ordinance took effect the following month, movie house operators claimed that advertised films were banned at the last minute, some actually pulled from the projection booth during performances. Melvin Winstock insisted that Portland's exhibitors were willing to cooperate with the Board but would not tolerate dictation. In April 1915, Edwin James, head of Portland's Motion Picture Exhibitors' League, 
filed suit to have the new Board's ordinance nullified. "'Every criminal has a right to appeal, why haven't we?"", protested James. Yet Circuit Court Judge Davis upheld the ordinance's viability in June. ${ }^{21}$

As acrimonious charges were exchanged through 1915, two representatives of the motion picture producers and exhibitors resigned from the censorship board in disagreement over the methods and opinions of panel secretary Mrs. E. B. Colwell. A number of prominent local public figures and groups soon joined theater operators in charging that the bureau was too powerful and was damaging the local movie business. Yet Mayor Albee and Board members resolutely refused to consider restoration of the appeals procedures and held their position. ${ }^{22}$

Despite hostility from the Portland Censorship Board, theater owners gained widespread public support for a medium that earlier had been characterized by limited audiences and a poor reputation. This came about because Portland's motion picture exhibitors had developed their theaters consistent with the perspectives and beliefs held by the independent film producers. Like the independents, they emphasized audience desires and sought patronage from the affluent classes. By 1916, downtown movie theaters also had established an image of community support and social responsibility. Complementing national film trends, the Portland motion picture industry had successfully cultivated 
the middle class audience essential for market success and legitimacy. 
CHAPTER IV NOTES

1. "Film Managers Organize", Oregonian (September 26, 1913), sec. 1 p. 6., "Movie Men Elect", Oreqonian (December 24, 1913), sec. 1 p. 11., "Tax On Movies Opposed", Oregonian (October 9, 1914), sec. 1 p. 4 .

2. "Time Given To Theaters", Oregonian (January 26, 1911), sec. 1 p. 13., "Safe Theaters Is Aim", Oregonian (April 28, 1912), sec. 1 p. 13., "Theater Rules Outlined", Oregonian (October 23, 1912), sec. 1 p. 12., "Theater Is Defined", Oregonian (August 27, 1913), sec. 1 p. 12., "Portland To Get $\$ 100,000$ Theater", Oregonian (February 15, 1914), sec. 1 p. 15., "Globe Theater Opens", Oregonian (September 15, 1912), sec. 1 p. 4., "New Arcade Is Opened", Oreqonian (April 4, 1912), sec. 1 p. 4., "Some Theaters Are Lax", Oreqonian (March 28, 1915), sec. 2 p. 16., "Theater Hands Stop Fire", Oreqonian (September 16, 1913), sec. 1 p. 16., "Film Burns; Women Faint", Oregonian (January 9, 1911), sec. 1 p. 7., "Blaze Most Stubborn", Oregonian (January 16, 1911), sec. 1 p. 7., "Theater Cleared Quickly", oregonian (May 10, 1913), sec. 1 p. 5., "Theater Burns On Fourth", Oregonian (July 6, 1914), sec. 1 p. 5., "Town Nearly Goes In

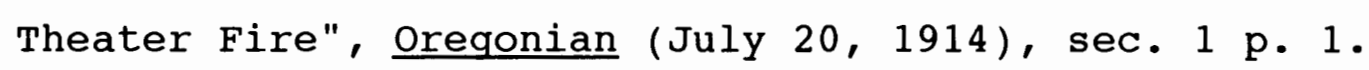
The code became effective April 1, 1912 . 
3. "Theater To Be Repaired", Oregonian (August 27, 1913), sec. 1 p. 9., "Theater To Reopen", Oregonian (November 26, 1913), sec. 1 p. 12., "Arcade Theater Is 'Dark'", Oreqonian (April 15, 1914), sec. 1 p. 4., "Majestic To Be Changed", Oregonian (May 21, 1914), sec. 1 p. 11., "Light Theater Is Boast", Oregonian (July 26, 1914), sec. 1 p. 4., "Sunset Soon To Open", Oreqonian (July 30, 1914), sec. 1 p. 9., "Theater Is Improved", Oregonian (January 5, $1915)$, sec. 1 p. 5 .

4. May, Screening, pp. 156-8., "Newest Movie Viewed", Oregonian (July 31,1914 ), sec. 1 p. 5.

5. "Babies Attract Crowds", Oregonian (July 26, 1912), sec. 1 p. 10

6. "Theater Plan New", Oregonian (July 9, 1911), sec. 4 p. 7., "Theatre Site Leased", Oregonian (March 12, 1911),

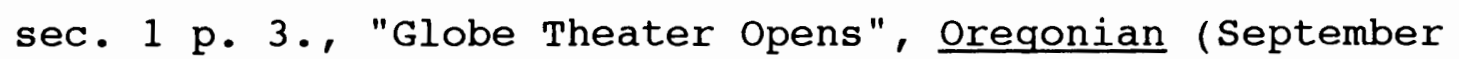
15, 1912), sec. 1 p. 4., "Fine Theater To Open", Oregonian (June 15, 1913), sec. 4 p. 8., "Portland To Get $\$ 100,000$ Theater", Oregonian (February 15, 1914), sec. 1 p. 15., "Sunset Soon To Open", Oregonian (July 30, 1914), sec. 1 p. 9.

7. May, Screening, 16., "Theatre Site Leased", "Jovians To Run Theater", Oregonian (April 25, 1915), sec. 1 p. 4. "Theater Sued By Negro", Oregonian (September 17, 1915), sec. 1 p. 9 .

8. May, screening, 150-155. 
9. "Peoples Theater", Oregonian (October 31, 1911), sec. 1 p. 13., "Globe Theater Opens", "Theater To Be

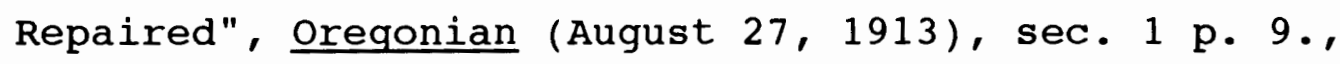
"Theater To Reopen", Oregonian (November 26, 1913), sec. 1 p. 11., Majestic To Be Changed", Oregonian (May 21, 1914), sec. 1 p. 11., "Another Theater Is To Rise At Once", "Theater Now 'Pickford'", "Portland To Get $\$ 100,000$ Theater".

10. "Boy's Friend Comes", Oreqonian (January 28, 1912), sec. 1 p. 13.

11. "Parole Policy In Film", Oregonian (February 11, $1912)$, sec. 1 p. 13., Kevin Brownlow, Behind The Mask of Innocence (Berkeley, 1990), 248-249.

12. "Ministers Invited To Star", Oregon Journal (April 26, 1910), sec. 1 p. 2., "Red Cross Seal Film Tells Tragic Story", Oregonian (December 18, 1910), sec. 2 p. 7., "Scientific Film Shown", Oregonian (April 24, 1911), sec. 1 p. 7., "Theater Invites Parsons", Oregonian (June 25, 1911), sec. 2 p. 20., "Films To show Child Life", Oregonian (July 25, 1911), sec. 1 p. 4., "Child Films Extolled", oregonian (July 28, 1911), sec. 1 p. 14., Advertisement-'Hope', oregonian (December 17, 1912), sec. 4 p. 3., "Film Censors Are Invited", Oregonian (December 24, 1912), sec. 1 p. 13., Advertisement- 'The Price of Human Lives', Oregonian December 17, 1912), sec. 1 p. 13., "500 To Judge New Film", Oregonian (September 30,1915 ), sec. 1 p. 7 . 
13. "Films To Show Junketers", Oregonian (March 22, 1912), sec. 1 p. 4., "Portlanders See Selves", oregonian (March 25, 1912), sec. 1 p. 7., "Film To Record Trips", Oreqonian (March 24, 1912), sec. 1 p. 13., "Motion Pictures Topic", Oregonian (September 9, 1912), sec. 1 p. $10 .$, "Eugene Picture Is Good", Oreqonian (October 20, 1912), sec. 1 p. 18., "Oregon Scenes Shown", Oregonian (July 28, 1913),

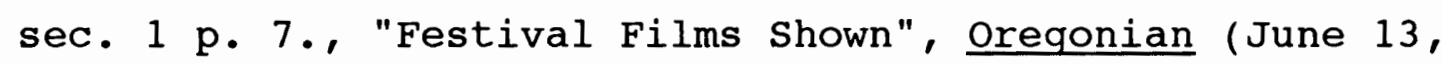
$1914)$, sec. 1 p. 12., "Movie Men Give Aid", Oregonian (January 5, 1915), sec. 1 p. 16., "Wild Life In Films", Oregonian (January 10, 1915), sec. 1 p. 15., "Celilo Films To Be Shown", Oregonian (July 28, 1915), sec. 1 p. 9.

14. "Pictured Crime Induces Murder", Oregon Journal (August 1, 1910), sec. 1 p. 4., "Sunnyside Fights Films", Oregonian (March 13, 1911), sec. 1 p. 7., "Crime Film Held Menace To Young", Oregonian (October 4, 1911), sec. 1 p. 3.," 'Movies' Mislead Youth", Oregonian (November 30, 1912), sec. 1 p. 1., "Indian Imitates Movies", Oregonian (January 15, 1913), sec. 1 p. 6., "Boy To Be Tried Today", Oregonian (January 27, 1913), sec. 1 p. 7., "Manias Laid To Films", Oregonian (February 5, 1913), sec. 1 p. 5., "National Censorship of Films Is Advocated", Oregonian (December 12, 1913 ), sec. 1 p. 14., Mrs. Robert H. Tate, Letter to Harry R. Albee (December 15, 1913)., Harry R. Albee, Letter to William T. Foster (January 2, 1914)., William T. Foster, Letter to Harry R. Albee (January 15, 1914)., Harry R. Albee, Letter to 
William T. Foster (January 17, 1914)., "Censor Board Appointed", Oregonian (January 18, 1914), sec. 4 p. 3., "Children May Need Parent At Show", Oregonian (January 25, 1914 ), sec. 1 p. 5., "Poster Censoring Urged", Oregonian (April 9, 1915), sec. 1 p. 18.

15. Advertisement - 'Enchanted Castle', oreqonian (March 30, 1910), sec. 4 p. 3., "Films To Help Library", Oregonian (October 12, 1912), sec. 1 p. 12., "Children To See Film", Oreqonian (November 14, 1913), sec. 1 p. 2., "Portland To Get $\$ 100,000$ Theater", Melvin Winstock, Letter to Mayor $\mathrm{H}$. $\mathrm{R}$. Albee (February 24, 1914)., Harry R. Albee, Letter to Melvin Winstock (March 3. 1914)., Melvin Winstock, Letter to Mayor H. R. Albee (March 4, 1914)., "Children To See Film", Oregonian (September 17, 1914), sec. 1 p. 4., "Education Films Sought", Oregonian (November 24, 1915), sec. 1 p. 12., "'Sunshine Sue' Charms", Oreqonian (November 16, 1914), sec. 1 p. 2., "Schools To See Film", Oregonian (November 22, 1914), sec. 1 p. 16., "Moving Picture News", Oregonian (December 20, 1915), sec. 1 p. 6 .

16. "Pattullo Urges Mayor To Stop Glove Contests", Oregon Journal (February 5, 1910), sec. 1 p. 1. "Demand That No More Prize Fights Be Permitted", Oregon Journal (February 7, 1910), sec. 1 p. 1., "Bain On Warpath Against Boxing", Oregon Journal (February 9, 1910), sec. 1 p. 1., "Salem Man Shows Fight Films", Oregon Journal (August 9, 1910), sec. 1 p. 10 . 
A theater manager was arrested for violating the state boxing law when he showed the Jeffries-Johnson fight film.

17. "No One May See Fight Pictures", oregonian (January 1, 1911), sec. 1 p. 16., "Ban On Fight Pictures Stands", Oreqonian (January 2, 1911), sec. 1 p. 14., "Police Suppress Fight Pictures", Oregonian (January 3, 1911), sec. 1 p. 18., "Ministers Discuss Pictures", Oregonian (January 3, 1911), sec. 1 p. 18. "Picture Promoters Talk", Oregonian (January $1,1911)$, sec. 4 p. 8 .

18. "Fight Films Implicate", Oregonian (November 4, 1911), sec. 1 p. 12, "Fight Pictures Are Off", Oregonian (August 17, 1912), sec. 1 p. 7., "Fight Films Up In Test", Oregonian (August 21, 1912), sec. 1 p. 11., "Fight Film War Grows", Oregonian (August 22, 1912), sec. 1 p. 5., "Fight Films Barred Out", Oregonian (August 27, 1912), sec. 1 p. 11., "Fight Film Is stopped", Oregonian (October 20, 1914), sec. 1 p. 19

19. "Board May Censor", Oregonian (March 9, 1911), sec. 1 p. 9., "Censor Is Opposed", Oregonian (March 18, 1911), sec. 1 p. 11., "Films Will Be Inspected", Oregonian (March $26,1911)$, sec. 1 p. 11

20. "Film Censors Are Stirred By Charge", Oregonian (January 30, 1913), sec. 1 p. 11., "'Sapho' Is Under Ban", Oregonian (January 10, 1914), sec. 1 p. 4., "'Sapho' Films Withdrawn", Oregonian (January 11, 1914), sec. 1 p. 1., "Censor Board Is Same", Oregonian (January 12, 1914), sec. 1 
p. 7., Harry R. Albee, Letter to Edwin F. James (November $25,1914)$.

21. "'Sapho' Films Withdrawn", Oregonian (January 11, 1914), sec. 1 p. 4., "Slave Films Viewed", Oreqonian (February 17, 1914), sec. 1 p. 4., "Slave Films Permitted", oregonian (February 21, 1914), sec. 1 p. 3., "Mayor's Eye on Movies", Oregonian (May 23, 1914), sec. 1 p. 11., "Movie Aid Is Solicited", Oregonian (June 5, 1914), sec. 1 p. 19., "Censorship Bowed To", Oregonian (June 6, 1914), sec. 1 p. 11., "Censors Block Heilig", Oregonian (June 15, 1914), sec. 1 p. 7., "Censors Want Powers", Oregonian (July 9, 1914), sec. 1 p. 9., "Proposed 'Movie' Law To Be Drastic", Oregonian (July 11, 1914), sec. 1 p. 14., "Movie Men Object", Oregonian (July 13, 1914), sec. 1 p. 7., "Censors Held Need", Oregonian (July 15, 1914), sec. 1 p. 9., "Film Man Replies", Oregonian (July 19, 1914), sec. 1 p. 11., "New Censor Act Drawn", Oregonian (July 26, 1914), sec. 1 p. 10., "Hearing On Movie Censorship Fails", oregonian (August 7, $1914)$, sec. 1 p. 12., "Heilig Film Is Passed", Oregonian (August 26, 1915), sec 1 page 5., "Women Censors Miffed", Oregonian, (October 2, 1914), sec 1 page 11., "Censorship Law Held Up", Oregonian, (October 2, 1914), sec 1 page 11., "Movie Men Protest", Oregonian, (February 8, 1915), sec 1 page 11., "Censor View Given", Oregonian, (February 9, 1915), sec 1 page 9., "Censor Act Passes", Oregonian, (February 20, 1915), sec 2 page 20., "Censorship Is Explained", Oregonian, (March 5, 
1915), sec 1 page 10., "Tolstoi Film Is Barred By Censors", oregonian, (March 8, 1915), sec 1 page 8., "Three Appointments Are Made In New Motion Picture Censor Board", oregonian, (March 8, 1915), sec. 1 p. 8., "Photoplay Gets O.K.", Oregonian (March 9, 1915), sec. 1 p. 11., "Film Censor Quits Post", Oregonian (March 10, 1915), sec. 1 p. 13., "Slave Films Repeated", Oregonian (March 16, 1914), sec. 1 p. 4., "Mayor May Be Censor", Oregonian (March 17, 1915), sec. 1 p. 3., "Censorship Is Near", Oregonian (March 21, 1915), sec. 1 p. 17., "Film Censors Elect", Oregonian (March 24, 1915), sec. 1 p. 13., "Officer Objects To Film", Oregonian (March 30, 1915), sec. 1 p. 8., "Poster Censoring Urged", Oregonian (April 9, 1915), sec. 1 p. 18., "Attack Is Made On Censorship Board", Oregonian (April 23, 1915), sec. 1 p. 7., "Of 647 Films 2 Barred", Oregonian (May 7, 1915), sec. 1 p. 12., "New Movies Inviting", Oregonian (May 22, 1915), sec. 1 p. 16., "Movie Men Face Trial", Oregonian (May 23, 1915), sec. 1 p. 19., "Censorship Talk Heard", Oregonian (May 24, 1915), sec. 1 p. 4., "Film Agent Is Fined", Oregonian (May 26, 1915), sec. 1 p. 4., "Film Censorship Legal", Oregonian (June 17, 1915), sec. 1 p. 11., "Naughty Film Attracts", Oregonian (June 26, 1915), sec. 1 p. 10., "Censors To Include Bars", Oregonian (June 27, 1915), sec. 1 p. 12.,

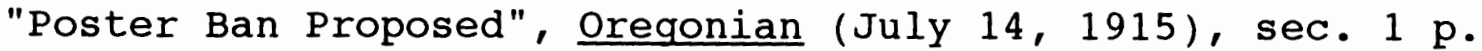
9., "Theater Manager Is Held", Oregonian (July 24, 1915), sec. 1 p. 3., "Movie Men Roused By Woman Censor", Oregonian 
(August 7, 1915), sec. 1 p. 4., "Heilig Film Is Passed", Oregonian (August 26, 1915), sec. 1 p. 5., "Film Seized, Is Released Again", Oregonian (December 10, 1915), sec. 1 p. 16.

22. "Censor Called Unfair", Oregonian (August 6, 1915), sec. 1 p. 4., "Movie Men Roused By Woman Censor", Oregonian (August 7, 1915), sec. 1 p. 4., "Storm Breaks At Censors"

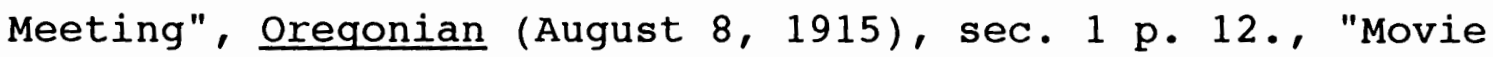
Censors Hit", Oregonian (August 11, 1915), sec. 1 p. 9., "Movie Appeal Law Is Up", Oregonian (August 11, 1915) sec. 1 p. 16., "Censorship Probe Due", Oregonian (August 13, 1915), sec. 1 p. 4., "Heilig Film Is Passed", Oregonian (August 26, 1915), sec. 1 p. 5., "Public Men Oppose Movie Censorship", Oregonian (August 29, 1915), sec. 1 p. 11., "Censorship Is Upheld", Oregonian (November 15, 1915), sec. 1 p. 12., "Thumbs Held Down", Oregonian (November 21, 1915), sec. 1 p. 18., "Movies To Ask New Act", Oregonian (November 25, 1915), sec. 1 p. 4., "Appeal Board Opposed", Oregonian (December 3, 1915), sec. 1 p. 13., "Film, Seized, Is Released Again", Oregonian (December 10, 1915), sec. 1 p. 16., "Moving Picture News", Oregonian (December 15, 1915), sec. 1 p. 6., "Moving Picture News", Oregonian (December 21, $1915)$, sec. 1 p. 8 . 


\section{CONCLUSION}

The premiere of 'Birth of A Nation' in 1915 epitomized Portland's middle-class acceptance of motion pictures. The film's national debut is generally accepted as the first indication of the widespread conversion to more affluent audiences. Likewise, its local appearance precipitated none of the official discontent that had plagued motion picture presentation. The usually surly local censor board wholeheartedly endorsed it, despite vociferous demands for its suppression by the local NAACP. And while it played at the Heilig Theater instead of a local movie palace, 'Birth Of A Nation' starkly revealed the new audience. Averaging close to one dollar per ticket, the film sold out continuously and was held over by public demand.'

This event represented the culmination of years of development by local exhibitors and national film-making companies. From the first nickelodeons to the huge 1915 edifices, audience conversion took barely ten years. The process, although often haphazard and experimental, was a complementary one. The initial success came with a largely lower-class audience, subjecting nickelodeons to disdain and regulation. While local exhibitors began with a desire to 
attract more upscale clientele, it took the New York Board of Censors to provide the first respectable approbation of films.

For the last five years of this period, both exhibitors and producers worked toward developing a product and environment attractive to a more affluent clientele. The success of D. W. Griffith's pioneering use of film story telling technique and his insistent victorian values influenced the industry to turn from predominantly foreign films. Nascent respectability expanded as producers discovered that emulation of stage theater entertainment increased middle-class audiences. Local exhibitors responded in kind, building large theaters similar in size, style, and grandeur to stage theaters.

Movie house similarity to stage theaters, however, was not entirely replication. Notions of class superiority and moral righteousness associated with legitimate theaters were not translated into the large movie palaces. While film venues began to attract affluent audiences, they did so democratically. Their appeal was meant to draw twentieth century urbanites to an oasis apart from their environment, offering the same feelings and experiences to anyone who paid admission.

The level film acceptability achieved by 1915 established a basis for what Lary May theorized as a source of mass social reeducation. The path to freedom and 
independence in a post-Victorian society was illustrated by the lifestyles of the new elite class the studios and star system created. Conspicuous consumption provided an alternative to stunted advancement in the corporate world while the magical culture in Los Angeles and Hollywood as a new frontier gave examples of activities possible in previously non-existent free time. While the urban immigrant found new means of upward mobility through these lessons, the middle class redefined achievement through consumption. ${ }^{2}$

Support by middle-class audiences was essential to the film industry's development. Evidence from the nickelodeon era proved established society's ability to hinder, if not wreck, the industry. Local regulation, civic concern, and especially the formation of the Portland Censorship Board revealed film exhibition's tenuous existence without middleclass acceptance. These patterns were enhanced by economics as the history of motion picture exhibition in Portland reveals, the film industry could neither support its expansion into greater productions nor realize expectations of greater profits without the support of a larger and more affluent class. 
CONCLUSION NOTES

1. "Film Is Protested", Oregonian (July 4, 1915), sec. 1 p. 3., "'The Birth of A Nation' Is Called World's Greatest Film", oregonian (August 22, 1915), sec. 3 p. 5., "Film Protest Is Made", Oreqonian (August 24, 1915), sec. 1 p. 6., "Heilig Film Is Passed", Oreqonian (August 26, 1915), sec. 1 p. 5., "The Birth of A Nation' Is Superb", Oregonian (August 29, 1915), sec. 4 p. 1., Advertisement - 'Birth of A Nation', Oregonian (August 29, 1915), sec. 4 p. 5., "Film Protest Is Made", Oregonian (September 1, 1915), sec. 1 p. 6., Advertisement - 'Birth of A Nation', Oregonian (September 5, 1915), sec. 1 p. 3., Advertisement - 'Birth of A Nation', Oregonian (September 12, 1915), sec. 4 p. 5., Advertisement 'Birth of A Nation', Oregonian (September 19, 1915), sec. 4 p. 5 .

2. Lary May, Screening out The Past (Chickgo, 1980), pp. 167-199. 


\section{APPENDIX \\ TOPICS IN ORDER OF APPEARANCE IN TEXT}

\section{CHAPTER 1}

KINETOSCOPE

In a Kinetoscope a film loop was strung along a series of sprockets on a board inside a free standing columnar wooden cabinet about four feet height with an angled top holding a viewing hole with a magnifying lens for each eye and a coin slot. Inserting a nickel activated the electric motor and turned on the light which was located behind the film at the point where it passed in front of the viewer's eyes.

Then, while bent over and peering intently into the box, one could see a tiny reproduction of probably a vaudeville visual act like a flexing muscleman or a dancer. Film ran on a circuitous route zig-zagging between sprockets and past the eyehole for about a minute and then all activity and light ceased.

The Kinetoscope's first extended display was in the Electricity Building at the Chicago Columbian Exposition in 1893. In August 1894 Edison allowed Norman Raff and Frank Gammon to form the Kinetoscope Company, which sold territorial exhibition rights. Kinetoscope films were initially all taken and processed at Edison's studio, the 
Black Maria, in West Orange, New Jersey. Raff and Gammon sold the machines to licensees for two hundred and fifty dollars apiece.

The earliest contemporary information about the Kinetoscope's presence in Portland was a tiny advertisement for the Corbett boxing match on machines at the Knickerbocker Block location.

The corbett match was a boxing contest simulated by James J. Corbett and Peter Courtenay at Edison's Black Maria, filmed on September 8, 1894. The "match" lasted for six approximately one and one half minute rounds which played on six consecutive Kinetoscope machines for a nickel per round. Kinetoscopes were adapted by Enoch Rector to accommodate the longer one hundred to one hundred and twenty six foot films each machine carried for one round of the fight. These films were distributed by a special company, the Kinetoscope Exhibition Company.

I. LEESER COHEN

I. Leeser Cohen read about the Vitascope in a Scientific American article and wired the Vitascope agents requesting the rights to present the vitascope on the Pacific coast, which he was granted for $\$ 1000$. Crates full of heavy and unassembled equipment and film were shipped to Cohen in Portland. With the help of his brother-in-law, Sam Rafael, and scrutiny of the Scientific American article, 
since the equipment arrived without any assembly instructions, he was able to form the mass into a working motion picture projector. After the performances at Cordray's Cohen acquired use of a vacant store "between Yamhill and Morrison streets" where he set up his equipment and paid a brass band to play in front of the place. ${ }^{1}$

For a week he showed the same films again and then learned that the Pacific Coast rights had been dealt out from under him, that another man had been granted the Vitascope rights to San Francisco. Cohen took the equipment and for the remainder of the time that it was available to him, projected films for audiences in various willamette valley locations, ultimately losing money on the venture.

CORDRAY'S THIRD STREET THEATER AND VITASCOPE

Edison's lab was unable to devise a way to regulate the speed of a film as it passed behind a lens so that it would project the image clearly and at life-like speed. Armat worked to create a device to move film intermittently past the lens, giving a frame's image a longer period of illumination behind the lens than the time taken in moving the film from frame to frame. The claw mechanism's development and adaptation of the Geneva cross device facilitated satisfactory projection. Edison bought the rights to these technological innovations.

At the 1896 debut at Koster \& Bial's in New York City 
film was projected on a canvas screen twenty feet square. The Vitascope held short loops of film in a spool bank like the Kinetoscope but Vitascope film differed, requiring a clearer base to give maximum illumination of an image.

Under Edison's name Vitascopes were marketed by Raff \& Gammon for rental. Vitascope projectors remained Edison property and travelled with film to each licensed location. The performances at Cordray's did not go without problems. The film was initially scheduled to open on Sunday night December 6 , but a railroad washout delayed the Vitascope's arrival in Portland. It wasn't available to Cohen and Rafael until late afternoon December 7, and even with the Scientific American's help they were not able to get the machine put together in satisfactory running order. Films shown the first night were blurred and shaky due to intense vibration in the just-constructed vitascope.

The scenes shown on the opening night were:

1 "a fire scene, representing a fireman on a ladder, receiving a boy and girl from a burning building and passing them down to a policeman."

2 "a comic review of the Monroe Doctrine represented Jonathan disciplining John Bull for his attacks on Venezuela."

3 "a ballet girl dancing..."

4 "two darkies of colossal size, having a watermeloneating match..." 
5 "The best effect was produced by the ocean scene, representing along a stone pier, extending out into the ocean, along which waves came rolling, gathering size and force until they reach the shore, curling up and breaking on the shore with a dash that sends the spray in all directions. This is the best scene of the lot, and...will prove the most interesting to everybody. Even last night, with the machine in bad working order, this scene secured a round of applause."

6 "The last scene represented the head and bust, colossal in size, of a man and a woman in what might be termed a kissing match."2

During the second week a skirt dance by Lucille sturgis and the third round of a "glove contest" were among the several added scenes. ${ }^{3}$

The ballet dancing girl film "was colored, but why her gauzy dress should change colors from green to yellow to red was not made apparent." 4

About the kiss film: it "was not particularly edifying, and a little of it goes a long ways" and it "verges a little on the risque order." "The film certainly created a sensation in the audience, and was run off all too quickly." 5

The bill was continued for another week "In order to accommodate the many who were unable to see the workings of the wonderful vitascope during the week just closed..." 6 
MARQUAM GRAND AND VERISCOPE

Enoch Rector had been involved with Edison when the Kinetoscope was introduced but had formed his own company, Veriscope, by 1897. The Veriscope camera differed from the Vitascope in taking pictures at twenty-four frames per second as opposed to the forty-eight which the vitascope cameras did.

Calvin Heilig arranged with Dan $A$. Stuart, the promoter of the fight, and the Veriscope company, led by Rector and Samuel J. Tilden, Jr., which had exclusive rights for filming James Corbett, to show the film at the Heilig. Distribution and film processing were still quite primitive at this time; the film was sent from the fight site in Carson City to the East Coast for processing, and then copies were sent out from there to licensed exhibitors.

\section{ARMORY AND ELECTROGRAPH}

The Electrograph projector, unlike the Veriscope, Vitascope or Projecting Kinetoscope which showed film run past a lens horizontally, showed film run past a lens vertically.

The filming dates for the two oregon films are unknown. However, they must have been taken at least several weeks earlier because there were no film processing facilities on the West Coast at this time, and all film taken in oregon, even as late as 1903, had to be sent back East for 
processing before prints were shipped back to oregon for viewing.

De Kannet's film program:

"A) After a storm. Wonderful water effects.

B) A Winter Afternoon In Central Park.

C) In A Carpenter's Shop.

D) Feeding The Pets.

E) A Business Street In Jerusalem.

F) A Caravan of Camels Leaving Jerusalem For Damascus.

G) Fishing In The willamette: a great comical scene, with a moral: 'Don't go fishing on Sundays'

H) On The old Bowery, portraying a remarkable scene of a crowd of over 2000 people, on that famous thoroughfare, on a hot summer afternoon, when suddenly the ringing of bells announce a

J) Great Fire Alarm. The entire fire department dashing by for the place of the fire in the following order: Chief and fire inspector: chemical engine, No. 1; fire engine No. 2; truck and ladder, No. 3; fire engine, No. 4 ; hose cart, No. 5; fire engine, No. 6. K) The Burning Building; showing great fire engine in full action and firemen placing ladders and directing streams of water against the building; the grandest, most realistic and thrilling fire scene ever presented on any stage. Inauguration of President McKinley 
L) Pennsylvania Avenue, during the great parade, showing the national capitol looming up in the background, one mile and a half distant. The march of different societies.

M) McKinley And Cleveland Going To The Capitol, and showing the accident of the day. The scene opens with the personal guard of President McKinley - the famous Black Horse cavalry, of Cleveland, $0 .$, followed by a four-horse barouche, occupied by President Cleveland and Major McKinley. At this point of the scene one of the rear horses attached to the president's carriage slipped and fell on the pavement. The mounted police gallop to the rescue, the carriage stops, and spectators are thus enabled to obtain the only effective view of the retiring and incoming presidents, the accident happening in front of the camera. N) The Great Hurdle Race of The California Jockey Club. Twenty thoroughbred horses coming straight at the audience and taking extremely high hurdles.

0) The Overland Mail. The O.R. \& N. overland flyer, on the banks of the Columbia River with the beautiful mountains as a background.

Z) La Danse Serpentine, by Lole Fuller with magnificent calcium effects." 7

These films were often interspersed between songs played by the band. $P, Q, R \& S$ on the program, for example, 
were non-film features and the first films were preceded by musical presentations.

The Electrograph's debut was marred by unfocused projection, blamed by the oregonian reporter on "faulty focusing, the operator seeming at times unable to control his apparatus."

MARQUAM GRAND THEATER AND KINEMATOGRAPH

The Kinematographe appeared at the Marquam Grand on May 18, 19, and 20, 1898. Spelling of the Lumiere Brothers' Cinematographe sometimes varied in this era, but the Marquam Grand's spelling and the timing of its appearance strongly imply that it was the Lumiere machine and if so, was also the first appearance in Portland of film produced outside the United States.

\section{VICLORAMA PARLORS}

Sketchy information implies that the Viclorama Parlors were analogous to a Kinetoscope parlor with several screens instead of peep show machines. The Edison films at the Viclorama Parlors were managed and presented by nonPortlander Sam Marx.

CORDRAY'S THIRD STREET THEATER AND TRIOGRAPH

By the end of 1896 Edison had updated his projection devices with the Edison Projecting Kinetoscope, which 
maintained similarities with the vitascope, showing film on a spool bank in short fifty foot loops. It provided its own light source and was powered by an electric motor.

Contemporary advertisements identify Cordray's April 1898 device as "Edison's Triograph", which is an unknown title. The timing of its appearance indicates that it might well have been the Projecting Kinetoscope.

With this new device Edison provoked a major change in film projection methods by offering the projector for sale to anyone. Previously all projectors on the market had remained property of the manufacturer and were rented to exhibitors, so it is likely that John Cordray purchased a projector for this show.

MARQUAM GRAND THEATER AND BIOGRAPH

The American Mutoscope and Biograph Company took form in 1895 and was led by W. K. L. Dickson, a former Edison employee critical to the Kinetoscope's development. On September 14, 1896, Biograph successfully introduced its own film projector which owed no legal technological debt to Edison's projection devices.

The large film showing the Jeffries-Sharkey match had frames two and three quarter inches by two inches, eight times larger than Edison film. Biograph projectors were standardized by 1902 .

The Marquam Grand acquired rights to show the boxing 
film through exclusive arrangement with william $A$. Brady and Thomas O'Rourke, who had arranged the bout which took place at the Coney Island Athletic Club in New York on November 3, 1899. It was shown on March 13, 14, and 15, 1900.

Ironically, in light of Biograph's conversion to standard size film, this was the only film during this period to be uniformly praised for its clarity and minimal eye disturbance.

YMCA

The YMCA featured film of Oberammergau, Germany's Passion Play along with some Spanish-American war topics.

EMPIRE THEATER AND STAR THEATER VENTILATION

Ventilation and a cool atmosphere was very important to vaudeville theaters in general because with their year round schedule they broke the dominant theatrical tradition of taking summers off when heat made theater going oppressive. The Empire was designed to deal with this; strong fans were placed outside the air intakes of the building and blew breezes over blocks of ice into the building, through the carefully constructed system, and onto the audience. When it opened the Star was enthusiastic about its ventilation system which, through two air pumps connected to air shafts in the ceiling cooled the audience. Being open-air, Shields' Park had no such concerns. The other vaudeville theaters, in 
more general terms, emphasized a comfortable environment.

PORTLAND VAUDEVILLE ADMISSION PRICES

Portland's vaudeville theaters all raised their prices on March 13, 1905. Thereafter ten cents bought not general admission but only the cheapest balcony seats; fifteen cents became general admission with box seats remaining at twentyfive cents. Pantages, shortly after taking over the Liberty theater, lowered general admission price to the pre-March 1905 rates of ten cents but within a month the Pantages was charging Portland's prevailing rate.

EDWARD T. SHIELDS

When he arrived in Portland in 1902 Shields had most recently lectured for the Chicago News and must have made arrangements with Chicago-based Selig during his time there. He showed two types of Selig films in 1902-03: regular entertainment films and footage of local oregon sights and events.

Edward Shields had worked and lived in Portland intermittently since the early 1890s when he married in Portland. He claimed to have introduced illustrated songs in town at Portland Heights in 1895.

\section{SHIELDS' PARK}

Shields attributed much of his theater's success in 
1902 to his prohibition of alcohol.

Shields' Park opened on June 21, 1902. Its initial capacity was three thousand and increased to more than four thousand with the addition of a balcony in July to accommodate the constant capacity crowds. Shields' Park was reconstructed for the 1903 summer season and held three thousand two hundred in its second season.

Open air theaters and Portland's climate were barely compatible. Although sporadic rainy evenings had preempted performances earlier in the summer, by mid-September even dry evenings were too cool for comfort and Shields' Park closed on September 14, 1902. In September each year Portland's stage theaters reopened for their new seasons; Shields' Park seems initially to have been designed to fill the entertainment void, rather than as a direct competitor. Before leaving in 1902 Shields announced intentions of building a permanent vaudeville theater in Portland. By May 1903 he had not, and from May 3rd through June 20th he used Cordray's theater for vaudeville while Shields' Park was being re-constructed at $13 \mathrm{th}$ and washington for the summer of 1903. The new Shields' Park, which bore almost no resemblance to 1902's Shields' Park, opened on June 22. Precipitation presented no problem in 1903 because Shields arranged to use Cordray's for his show when it might rain.

He returned in the summer of 1904 and again constructed Shields' Park, but he presented light comedies and plays 
instead of family vaudeville with disastrous results. Shields' Park was bankrupted and closed unceremoniously on August 7, 1904, before the scheduled end of its season. Shields' Selig cameraman's identity or the number of Selig representatives in Portland is unknown. In 1902 filming occurred over a three day period in late May-early June. Portland's Decoration Day parade of Friday, May 30, 1902 was filmed as were scenes of a crowd leaving the Baker theater after a performance of 'The Silver King' on Sunday afternoon June 2 .

Shields presented views of the Portland Hunt Club's hurdle race and drill at Irvington in July and August. Shields himself photographed at least one of these films. It is unclear if the second Hunt club film showing in the summer of 1902 differed from the first.

Chicago played a part even in the local footage. Portland had no motion picture processing facility. Film negative taken in Portland was shipped to the Selig studio in Chicago where it was developed, evaluated for acceptable quality and printed. Prints were then sent by train back to Portland and shown at Shields' Park. The process took about two weeks minimum from local filming to local screening. In mid-June Shields listed local views that would be shown. In addition to those previously mentioned, the Portland Fire Department and the steamer Bailey Gatzert shooting the Cascade Rapids would be filmed. Actual 
presentation of these subjects was never noted.

While he was presenting vaudeville at Cordray's in May and early June 1903 Shields featured film of President Roosevelt's May 20 visit to Portland. Selig's Thomas Nash was in town to take Columbia River Gorge footage for the Oregon Railway and Navigation Company and filmed the parade planned in Roosevelt's honor as it wound through downtown Portland.

Shields himself remained closely involved in Selig's Oregon activities. In one of the Gorge films he took part on screen with Wilber E. Coman, an O.R. \& N. passenger agent, running comically to avoid an oncoming train at the Needles. Later, on August 2, 1903, he accompanied an unidentified Selig cameraman to the Portland baseball park. Between the fourth and fifth innings the game between Portland and Los Angeles was stopped. In his red automobile, Shields and the cameraman drove around the perimeter of the field. The players of both teams lined up in front of the grandstand and were photographed. Then Shields and company drove up along the grandstand taking care to get clear photographs of persons in the crowd, including local luminaries. After the game they employed the same strategy in filming the crowd as it left the park.

EMPIRE THEATER

The Empire opened on June 15, 1903 in a building with 
no previous theatrical history. It was built specifically for vaudeville and completed soon before its opening. It seated one thousand five hundred. The Empire gave its last regular vaudeville performance on November 8, 1903 before switching over to popular plays. During its vaudeville period the Empire rarely played to full houses.

Indications are that Baker was not as adept as Shields at presenting vaudeville. The oreqon Journal complained about Baker's tendency to break the rhythm of the show by holding a ten-minute intermission which annoyed the patrons. Baker may have been attempting to economize with a break instead of another act. Budgetary restrictions would also account for the lack of first class acts despite the pool of talent accessible through the Empire's arrangement with the Orpheum circuit. By the Fall of 1903 its shows were reviewed in such terse terms as "poor" and "cheap vaudeville".8

The Empire advertised its films generally as "American Bioscope". Although George Baker was proprietor, the Empire's bills were arranged by the Northwest Pacific Coast Vaudeville circuit which was connected with San Francisco's Orpheum circuit. Since big-time vaudeville was the motion picture's steadiest supporter, the Empire's films were probably provided by the larger circuit. The film companies doing business with the film procurers, however, are unknown. 
S. MORTON COHN

S. Morton Cohn had been a Portland agent for the Transcontinental Machine Company which supplied slot machines. By 1902, Portland was experiencing a crackdown on slot machines, particularly in saloons, inspiring Cohn to focus on other activities.

\section{ARCADE THEATER}

In $1903 \mathrm{~S}$. Morton Cohn owned the Arcade at 7th \& Washington, which stood on land owned by John J. Jennings. It was apparently a penny arcade, of which there were many in downtown during this era. Early in August Cohn joined with Shields to create a vaudeville theater out of part of his arcade. Shields was to book the acts, to serve as manager and to receive twenty percent of the gross weekly profits as his salary. Beginning about August 7, 1903, Shields also supervised the arcade's alterations.

The theater's entrance was a penny arcade area which remained functional after the alterations, and the Arcade held only five hundred. This unorthodox entrance at 330 Washington Street led to the Arcade Theater. Shields and Cohn hoped to open it by October first but weren't ready until the twelfth.

Barely one week after it opened Shields was removed from his position and cut off entirely from any activity with the theater. Cohn claimed that he was unhappy with the 
character of the acts that Shields was booking. During that one week Shields was in charge the shows' contents were praised just as highly as they had been during his previous two summer seasons, and attendance was as great as it could be.

In November Shields filed suit against Cohn for reinstatement and for the salary he was being denied. It apparently failed. Shields had no further involvement with the Arcade in Portland.

The Arcade opened showing Selig films. Shields was apparently necessary to the film acquisition arrangement between Selig and the Arcade. After Shields' removal until it stopped vaudeville the Arcade continued showing films but under the title "American Bioscope". The term Bioscope refers to a projector devised by Charles Urban of Detroit. It did not rely on electricity and was relatively lightweight and portable. Film was moved through it by the operator's hand power. For a light source it employed what a regular theater would probably already have on hand - a calcium light, commonly used for illumination in slide and stereopticon projection. Given the standardization of film size and speed of most companies including Biograph by this time the Bioscope was able to show most any company's films. Cessation of Selig service forced Cohn to diversify the origins of the Arcade's films, although this still required direct dealing with a film's company of origin. Through 1905 
the Arcade definitely showed both Edison and Biograph products.

The Arcade added a motion picture screen framed in gold in May 1905.

CENTRAL PARK THEATER

The Central Park Theater, an obscure family vaudeville theater, opened on the East side in 1903. It was built by the Leandor Brothers and J. M. Magrath and opened at the corner of Grand and Taylor on April 3. Its advertisements ceased shortly after its opening, implying that it failed rather quickly. Since it was an open air theater, it was probably only intended for a summer run.

\section{EDISON'S THEATER}

On January 30, 1904 a vaudeville theater named Edison's opened on East Burnside between Union and Grand. Its ownership and duration are unknown.

\section{BIJOU THEATER}

Fred Merrill was a sometime-city councilman who ran the Cyclery Building in the 1890s. He attempted some theatrical promotions in the early 1900 s without stunning success.

The Bijou abandoned vaudeville on January 21, 1905, but continued showing film during intermissions of its stage productions. 
KEATING AND FLOOD

Keating and Flood flourished as a business partnership beyond 1915, when their interests expanded as far as Seattle. The 1904 Lyric seems to be their first Portland theatrical venture.

\section{LYRIC THEATER}

The Lyric opened on May 8, 1904 with a capacity of seven hundred. Seating was increased by four hundred and fifty with addition of a balcony in June. On January 21 , 1905, the Lyric ceased vaudeville presentations.

An unknown, independent vaudeville circuit supplied Keating \& Flood for their Lyric shows. Unless they had a better arrangement than any other vaudeville-film entrepreneur in Portland in this turgid film supply era there is no other way to explain the variety of film companies represented there in 1904. Only Sullivan \& Considine theaters in Portland had as large a range. The Lyric's advertisements of the "Vitascope" clarify nothing. After the Lyric switched to stock company shows it continued showing films for awhile as an intermission device, probably while scenery was being changed backstage.

For the next ten years Keating \& Flood ran at least one theater in Portland, usually called the Lyric, although in two or three different locations. They devoted their resources to vaudeville most consistently during the Lyric's 
1904 season.

The Lyric in 1904 assured women and persons of taste that "Chinese and objectionable persons" were barred from the premises. 9

ORPHEUM AMUSEMENT COMPANY AND ORPHEUM THEATER

The Orpheum opened on April 27, 1904. On July 29, 1904, a robbery complaint was filed with the police. A man claimed to have had a one hundred and fifty dollar diamond pin stolen from his person at about $2 \mathrm{a} . \mathrm{m}$. while he was in the Orpheum.

The police commented that the owners had been arrested the previous week for keeping the orpheum open after hours, and chief Hunt thought it was about time "the orpheum saloon is closed for good." 10

Mr. Heintz of Pacific Iron Works filed a suit on September 9, 1904. The Orpheum had not yet paid for building repair materials received in April. Pleading financial difficulty, the owners arranged a payment plan with Pacific to pay back the three hundred and forty eight dollars before the suit reached court.

The Orpheum's reputation did not improve during the annual liquor license renewal process with the city in December. There was much opposition to it based on complaints of gambling and the presence of women in the theater. Despite this it was relicensed on December 29, 
1904.

The next year was not much kinder to the orpheum. It experienced a near disaster when a dancing girl narrowly avoided serious injury from a falling scenery backdrop. Then, on May 19, its liquor licenses (it contained two bars, each with a license) were revoked for failure to comply with a promise to keep women from soliciting drinks in the saloon's private boxes. The orpheum was not closed but apparently lost its commercial viability with its liquor licenses.

BAKER THEATER

It limped along through the summer until Keating \& Flood gave it new life. They had leased the Baker Theater for vaudeville from October 23, 1904, until August 1905. Their lease expired, and George Baker resumed active management of the Baker, giving stage performances.

\section{GRAND THEATER}

The Grand Theater opened on November 20, 1904, in John Cordray's old Third street Theater building. Claiming no interest in selling, Cordray named what he thought was a ridiculous price. He was astonished when Considine accepted. Cordray's theater was sold for fifty thousand dollars. Left without a Portland theater, Cordray joined Sullivan \& Considine as a theatrical representative. 


\section{LIBERTY THEATER}

Keating \& Flood took over the Orpheum Amusement Company's lease for the 4 th \& Stark theater on September 24, 1905. The lease had four years left when they took possession on October $9 \mathrm{th}$. After a few weeks' remodeling it was renamed the Liberty Theater and opened for family vaudeville on October 30 th.

\section{STAR THEATER}

The Star was one of a chain of fourteen oregon and Washington vaudeville theaters known as the star Circuit, owned by S. Morton Cohn and Peter Gevurtz. The Portland Star Theater held one thousand. Late in 1904 Cohn sold control of the Star Theater (probably leased) in Portland to Sullivan \& Considine as part of the overall sale of Cohn and Gevurtz' star circuit to Sullivan \& Considine.

The Star Theater's two managements during this period amounted to two different film sources. Under Cohn from June 1904 until late in 1904 both the advertisement of "Edison's Projectoscope" and identification of the few known film titles imply that an arrangement existed solely with the Edison film company.

Under Sullivan \& Considine's control the star probably received film supplied by the larger circuit. Without local proprietorship the Star's task of finding films was thus simplified, and it showed at least Biograph, Edison, Lubin 
and Melies films.

The Star offered a waiting-maid in its specially designed ladies' dressing room, while also employing a maid to watch over children of parents without babysitters. Children were encouraged to attend the shows as much as women. While at Cordray's in 1903 Shields admitted children under eight free to weekday matinees.

The Arcade and Star both offered reservable box seats beginning in July 1904 .

The Star added stage theater playlets to their bills in July 1904, based on their introduction by J. Austin Fynes at Keith's Union Square Theatre in New York.

On August 1, 1904, Oliver Taylor attempted to use his box seat tickets at the Star Theater. The usher refused to seat him because he was black and told him that the Star's policy did not allow blacks to occupy boxes in the front of the theater. He was not told to leave, merely that he couldn't sit in the box seats even if he had paid for them. On May 18, 1905, circuit court judge Frazier upheld S. Morton Cohn and the Star theater's policy.

When Sullivan \& Considine leased it at the beginning of 1905, Max Cohen became the Star's new manager. Chris 0. Brown, Cohn's manager of the Star, was retained by Cohn as a theatrical representative for the Star Theater.

By May 6, 1906, Sullivan \& Considine ended vaudeville at the Star. Considine reopened it a week later presenting 
musical farces until August 20 th when it was again closed and remodeled preparatory to its opening as a dramatic stock company's home.

\section{ALEXANDER PANTAGES}

The Alaskan gold rush provided Pantages' initial fortune. Based in Seattle, he had begun forming his own western states vaudeville circuit during the previous couple of years.

On December 14, 1905, Keating \& Flood sold their Liberty Theater lease to Alexander Pantages for twenty thousand dollars, and it became the Pantages on December 25 .

\section{PANTAGES THEATER}

The Pantages spent its first few years in Portland with one specific film source. John A. Johnson, local Pantages manager, made special arrangements with the Biograph company whose films were shipped direct from New York.

\section{FREDERICKSBURG MUSIC HALL}

The Fredericksburg Music Hall presented a weekly bill including "vitograph" films on screen. It made a halfhearted attempt at a family vaudeville audience for its matinees, at which it sold no liquor. But it was not regarded as respectable vaudeville; newspapers gave it no attention as such and never reviewed its bills as they always did 
Shields' Park's.

FRITZ'S NEW THEATER

Fritz's New Theater, at 240-246 Burnside, similarly advertised motion pictures in the form of Edison's Kinetoscope. It, too, eluded local press reviews.

PORTLAND FIRE COMMITTEE

On August 20 Max Fleischner recommended that a committee be composed to inspect the city's theaters and that if the two firemen idea should be adopted the theaters should be responsible for paying the firemen if the city lacked the funds.

Max Fleischner, Mr. N. J. Blagen, John Montag, and Fire Chief David Campbell comprised the committee appointed to evaluate the city's theaters on september 11, 1905. The inspections found many infractions and violations among the theaters and made recommendations for their correction.

For their part, most managers were willing to comply with the recommendations. They were, however, adamantly against the pay-for-two-firemen proposal, especially after the city ways and Means Committee determined that the city did indeed lack the funds for such a plan.

To insure compliance with the existing laws Fire Chief Campbell, Assistant Fire Chief Laudenklos, and Deputy Fire Marshall W. R. Roberts reinspected theaters on October 10 
and 11,1905 . They filed their conclusions in a report to the city executive committee on the 20th. The city council reiterated its determination by threatening to close theaters and revoke licenses if the ordinances were not immediately obeyed. Unwillingness to pay fifteen thousand for necessary rewiring caused its owners to close the Marquam Grand in March 1906.

\section{LOCAL VAUDEVILLE AND FILM REPUTATION}

The Oregon Journal article excoriated the arcades as dens of shame. Most of the arcades teased patrons with double entendre posters and titles. Many showed scenes of chorus girls in un-ladylike activities and poses; other lampooned proper social and religious standards.

Each arcade held rows of machines, most charging a penny apiece. Arcades also housed games like knife racks and shooting galleries run by shady characters, some with criminal records.

The Epworth League was a national Methodist organization. Its Oregon chapters were particularly cohesive, and one of their tenets was an absolute disassociation with all worldly amusements. In practice, League officials wavered throughout the decade from 1905 through 1915, wrestling with the knowledge that many of their own members disregarded this rule and agonizing almost annually over its repeal or enforcement. 
VAUDEVILLE ORDINANCE PROPOSAL

In December 1904 councilman $\mathrm{Z}$ immerman proposed a three hundred dollars monthly licensing fee for Portland's tencent theaters. This was during the peak of Portland's initial vaudeville proliferation, and those were the only ten-cent theaters in town. The proposal was not adopted.

CHAPTER II

CAMERAPHONE THEATER

A theater called the Cameraphone opened at 127 th street on February 25, 1909. It was named for an early sound film company that didn't prosper. The building soon changed management, ultimately becoming the National Theater by 1910

MELVIN G. WINSTOCK

Melvin Winstock was a politically active Portland attorney who worked hard and successfully for Theodore Roosevelt in the 1904 election, giving sixty speeches in Maryland for the Republican ticket. Feeling that Maryland was a lost cause, the Republican National Committee had committed no funds to campaign there. Winstock was given credit for Republican victories in Maryland and West Virginia. A judicial appointment was rumored to be his likely reward and during the next few years he served as 
Seattle's district attorney. During this same period he worked for Alexander Pantages and was involved in the Northwest's power struggle between Pantages and Sullivan \& Considine. By 1909 he had returned to Portland acting as legal representative for S. Morton Cohn's Associated Investment Company.

HARLEY C. STEVENS, JR.

Harley C. Stevens, Jr. came to Portland in 1906. By 1907 both he and his father worked as electricians. Before joining Cohn's exchange he ran his own film exchange which he opened sometime in 1908. Stevens Film Exchange, its equipment, and Stevens' experience formed the basis of the Amalgamated Film Exchange.

\section{NICKELODEON OPERATIONS}

The Nickelodion began operations changing its bill twice a week. Initially it showed new films on sunday and Wednesdays but switched to Mondays and Thursdays by the end of 1906. By June 1908 the Nickelodion was changing bills daily. Despite the lengthening of film topics by 1909 the star, too, changed its bill twice a week, on sunday and Wednesday.

Operation hours lasted up to twelve hours daily. The Nickelodion was open from eleven a.m. to eleven p.m. seven days a week. Harry Shuman showed films daily but only 
between five thirty and eight thirty p.m. Hale's Tours opened at two p.m. and probably closed at ten or eleven p.m. The Star was similar except that it made concessions to increase Sunday revenue. Monday through Saturday the star ran from two p.m. until ten thirty p.m., but on sundays it usually opened an hour earlier and closed a half hour later.

In 1906 the Nickelodion's program began about every fifteen minutes, during which up to five films were shown. The length of a normal film topic at that time averaged only about three hundred feet or about three to four minutes. By 1909 the film industry regularly produced films averaging five minutes on screen. The Star's six-film bill ran for about thirty minutes.

Since films were commonly untitled and uncredited during this period, the projectionist usually shouted out each film's title over the projector's rattle.

\section{NICKELODEON PROFITABILITY}

Despite courting a classier audience motion picture theaters were instantly good business ventures. At the end of 1908 the average weekly attendance at the largest of Portland's movie theaters, probably the Star, was estimated at ten thousand to twelve thousand. Using the ten thousand attendance figure and taking the average costs of regular monthly expenses a five-cent movie theater owner stood to realize a gross profit of two thousand dollars per month. 
Using the twelve thousand attendance figure and highest costs of all the monthly expenses a ten-cent movie theater could attain a gross profit of four thousand eight hundred dollars per month. Profitability was accentuated by the relative ease and low maintenance required to run such a theater; it need only be a leasable space in the right area, requiring no actors, a minimal paid staff, and relations with an effective film exchange to maintain a supply of first run films.

\section{NICKELODION}

There's no indication that st. Peter lived or worked in Portland before the Nickelodion's opening at $1306 \mathrm{th}$ St. When he expanded to create the Nickelodion East at 145 Grand the original was known as the Nickelodion West.

A. B. Lewis Gellerman probably bought the Nickelodion in August 1908 and for a short time renamed the West side Nickelodion the Pioneer, the Nickelodion East disappearing at about this same time. Gellerman increased his motion picture involvement in 1910 when he became local president of the Independent Western Film Exchange and was also president of the Cyclohomo Amusement Co. At some point in 1912 he seems to have left Portland, but the Nickelodion remained a Gellerman business, being managed by Bernard E. Gellerman after 1914. Bernard Gellerman had run a small motion picture theater at 109 1st in 1908-09, and in 1913-14 
he ran two theaters situated across the street from each other on the East Side, the Pictureland at 674 Alberta and the Victoria at 665 Alberta. The Concordia Club had established a new building on Morrison and 16 th street in 1905; so the original Nickelodion occupied a building past its purpose. Demolition of the old club building forced the Nickelodion's reestablishment on 6 th street.

HALE'S TOURS OF THE WORLD

Conceived by Captain George Hale of the St. Louis Fire Department, Hale's Tours' Portland franchise opened in March 1906.

\section{HARRY SHUMAN}

The 3rd and Morrison location cited "Harry Shuman, General Advertiser" on its sporadic ads. It ran for about four months beginning in september 1906.

ORPHEUM THEATER (IMPERIAL AMUSEMENT COMPANY)

The Orpheum Theater was located at $1086 \mathrm{th}$, the Palace at 251 1st, and the Hippodrome at 109 6th. The Hippodrome was taken over by the London Spectroscope Company in 1909.

STAR THEATER

Cohn actively used the star theater in 1907 after expiration of Sullivan \& Considine's lease. It remained 
inactive in vaudeville and film until July 1908. From July 7 to the 14 th the star showed a bill consisting of a pair of synchroscope films. Synchroscope were early sound films. They elicited little comment and were not heard of in Portland again. Cohn opened the star for films in February 1909 for a short period before instituting them as regular fare beginning in April.

The star seated about one thousand.

MARQUAM GRAND

The Marquam Grand experimented with film bills three times during the first half of 1908 before it closed and the theater portion of the building reopened in August as the orpheum. It closed entirely at the end of March 1906 when its owners were unwilling to pay the cost of bringing its electrical wiring up to code. In May 1907 the Marquam Grand, under new ownership and in compliance with city ordinances, reopened and commenced presenting road show attractions.

During the first week of January 1908 a Pathe version of the Passion Play was featured at the Marquam Grand, timed for the Christmas holiday. On two occasions in March 1908 the Marquam Grand presented a bill of Pathe films when the theaters would have otherwise been dark due to the absence of a road show troupe. From March 9 th through the 15 th it showed a bill of three films and "found it so profitable" that it showed a bill of four Pathe films from March 19 
through April 4.

EXPOSITION RINK

A Passion Play film was also available to the public from January 2 through 8, 1908 at the Exposition Rink on Washington street near 20th. It was literally a skating rink serving as a five thousand seat-capacity theater for this one week presentation, which featured music by DeCaprio's band, singing by Mrs. Millie Perkins and an explanatory lecture by Francis collins.

\section{MILES BROTHERS}

In 1902 Harry and Herbert Miles of San Francisco developed the idea of buying films from a producing company and then making them available, on a rental basis, to any interested theater owner in the area. It afforded theater owners easier access to a larger supply of films and created the film exchange business. Miles' Brothers Portland exchange was at $1071 / 26$ th Street and may have supplied the Nickelodion.

\section{AMALGAMATED FILM EXCHANGE}

Probably a regional exchange business, the Amalgamated Film Exchange was located at $1421 / 24$ th Street. Melvin G. Winstock served as its vice president, A. L. Levy was treasurer, and Harley Stevens, Jr., remained as the 
company's day to day manager.

SAMUEL NEWMAN'S WAREHOUSE FIRE

Samuel Newman ran a theatrical supply house in Portland at 293 Burnside. Among the items stored in his warehouse were illustrated song slides and motion pictures. On March 22, 1909, a fire of undetermined origin broke out, burning among other things six hundred thousand feet of film. The fire was contained within its building of origin.

ORPHEUM THEATER FIRE (IMPERIAL AMUSEMENT COMPANY)

In June 1908, the Imperial Amusement Company's Orpheum Theater experienced a scare. Projectionist Julian Dills acted quickly when he heard an explosion-like sound in the projector. A fire immediately erupted, and he fled the projection booth after making sure the asbestos and metal reinforced booth was sealed. The fire burned itself out, and no one was injured.

PORTLAND FIRE COMMITTEE

In March Marcus Fleischner proposed to the executive board's fire committee that the city appropriate funds for six firemen for the sole purpose of theater protection. The only fault found with this plan was, as before, who should pay for them, the city or the theaters. On April 14th, councilman Kelleher introduced a prospective ordinance 
calling for six firemen and their funding by the city's theaters.

Dobson was instrumental in promoting this ordinance. He actively agitated for laws calling for the elimination of frame theaters altogether in Portland within the next four to five years. Most of the stage theaters in town as well as the motion picture theaters would face condemnation under such rules. The Arcade drew Isaac Swett's denunciations in the city executive committee in January 1909. Even though it wasn't currently being used as a motion picture theater and had been in use as a theater for several years, swett complained of its shoddy conditions and fire danger.

CHAPTER III

FILM SUPPLY COMPANY OF OREGON

Blitz's successor as vice president was Samson $\mathrm{w}$. Herrman, president of the Holman Transfer Company. Alexander Bernstein, who had been instrumental in Film Supply's establishment, served as its secretary from 1912 until 1914. Similarly, Gus Metzger served for the same period as treasurer-manager and remained in that position after Carl Laemmle acquired Film Supply in 1914. As a Universal distributor under Laemmle, the local board of Film Supply listed Laemmle as president, R. H. Cochrane as vice president, and W. E. Shively as secretary. 
LAEMMLE FILM EXCHANGES

Laemmle's first exchange in Portland opened in 1908, was called the Laemmle Film Service Alliance and was located at 508 Couch building at the corner of $4 \mathrm{th} \&$ Stark. It retained the same name when it moved in 1911 to 333 Oak. When Laemmle took over the Film Supply Company of oregon in 1914 the Film Supply Company name was retained as was its location at $3851 / 2$ Alder.

\section{PEOPLES AMUSEMENT COMPANY}

The PAC continued very successfully through 1915. Despite its property divestiture in Portland, it still remained a business force throughout oregon. It lost its best promoter, Melvin Winstock, in February 1914, when he left to do bigger things. In October 1914, John F. Cordray, Portland's old theatrical pro, took over as general manager while maintaining his ownership of the United Amusement Company, which ran Oaks Park. Yet Cordray remained in the PAC for only a short while, resigning on May 13, 1915 to devote all his energies to the United Amusement Company. By the end of 1915, PAC's only Portland holdings were the Peoples Theater and the Pickford Theater.

PALACE THEATER (PEOPLES AMUSEMENT COMPANY)

The Palace Theater was located at 251 lst St. 
ORPHEUM THEATER (PEOPLES AMUSEMENT COMPANY)

The Orpheum theater was at $1086 \mathrm{th}$ St.

OH JOY THEATER (PEOPLES AMUSEMENT COMPANY)

The Oh Joy Theater was at 351 Morrison Street.

ODEON THEATER (PEOPLES AMUSEMENT COMPANY)

The National Theater, at $1355 \mathrm{th}$, was bought from British Columbia's Pacific Amusement Company and opened as the Odeon on May 11, 1910.

The Odeon's space was leased to the PAC with the understanding that its building would be torn down when the lot's owners decided to construct their projected 12-story building. The Odeon closed on April 30, 1911. PAC opened a new Odeon at 135 1st later in 1911, which functioned until sometime in 1913.

STAR THEATER (PEOPLES AMUSEMENT COMPANY)

The Star became the Pickford theater on October 27, 1915 .

ARCADE THEATER (PEOPLES AMUSEMENT COMPANY)

The Arcade's lease expired on April 1, 1914.

BIJOU THEATER (PEOPLES AMUSEMENT COMPANY)

The Bijou theater was located at 1267 th St. 
PALACE THEATER (PEOPLES AMUSEMENT COMPANY)

The Palace theater was released to Oscar J. Mayer in 1914 .

MELVIN G. WINSTOCK

Melvin G. Winstock, who served as general manager, played a leading role not only in the PAC but in the support of motion picture theaters throughout portland in the next five years. Although his involvement with $\mathrm{S}$. Morton Cohn was likely his invitation to the PAC, winstock's demonstrable show business and public relations experience qualified him for his position. In addition to his work with Cohn, he authored sketches and plays. One of his scenarios, 'A star In Pawn', was produced by the Edison Company in 1911 or 1912 .

PEOPLES THEATER (PEOPLES AMUSEMENT COMPANY)

PAC leased the land from the D. P. Thompson estate in May 1911 for ten years at one thousand dollars per month. The J. F. Wineland company began construction on the one hundred by one hundred foot lot in July 1911 promising to build the one hundred thousand dollar steel and concrete structure in one hundred and four days.

The Peoples Theater was originally scheduled to open on October 15, 1911. At its November 1 opening, management employed a superstition with the first customer; after the 
first ticket was bought the box office gave the money back and rewarded the customer the ticket gratis.

The original structure stood until its demolition late in 1993.

HIPPODROME THEATER (PEOPLES AMUSEMENT COMPANY)

The London Spectroscope Company had acquired the Hippodrome Theater at 1096 th St. from S. Morton Cohn and appointed Metzger manager. The Bijou, Hippodrome and the Oh Joy's inclusion in the PAC allowed Metzger to be one of its founders.

TIVOLI THEATER (PEOPLES AMUSEMENT COMPANY)

The name "Tivoli" was chosen as a result of a theaternaming contest which rewarded the winner twenty dollars in gold. It opened at 515 williams Avenue on October 30, 1910 and was constructed for ten thousand dollars.

CRYSTAL THEATER (PEOPLES AMUSEMENT COMPANY)

The Crystal theater opened at 125 Killingsworth, at Killingsworth and Albina, on August 18, 1912, costing fifteen thousand dollars.

SUNNYSIDE THEATER (PEOPLES AMUSEMENT COMPANY)

S. Morton Cohn acquired a sixty six by one hundred foot lot for the PAC in the Sunnyside district in March 1910. The 
Sunnyside Theater, costing twenty five thousand dollars, opened on July 31, 1912, at $10451 / 2$ Belmont. By the beginning of 1914 the theater was run by Clarence $w$. Batcheller, who had been partner with Frank Sax in running the Grand Avenue Theater (for movies) at 92 Grand Avenue from 1909 into 1911.

ST. JOHNS THEATER (PEOPLES AMUSEMENT COMPANY)

PAC manager Gus Metzger stated intentions to build a film theater in St. Johns in February 1913 at a projected cost of thirty thousand dollars.

ORPHEUM THEATER IN LA GRANDE (PEOPLES AMUSEMENT COMPANY)

The Orpheum in LaGrande was acquired by PAC in February 1911.

STAR THEATER IN ASTORIA (PEOPLES AMUSEMENT COMPANY)

The PAC spent twenty five hundred dollars refurbishing the Star theater in Astoria preparatory to Astoria's Centennial Celebration in August 1911.

STAR THEATER IN MEDFORD (PEOPLES AMUSEMENT COMPANY)

Local Portland PAC theater manager Al Sather was dispatched to Medford as manager of the newly built star Theater which opened on September 2, 1911. 
STAR THEATER IN CALDWELL, ID. (PEOPLES AMUSEMENT COMPANY) PAC owned the Star theater in Caldwell, Idaho, and the two seattle theaters from its inception in February 1910.

MAJESTIC THEATER (JAMES AMUSEMENT COMPANY)

The washington street Majestic Theater had an interior area of sixty by one hundred feet. Its renovation was designed by the architect E. V. Houghton, and James' lease ran for five years at three thousand dollars per month.

PRINCESS THEATER (JAMES AMUSEMENT COMPANY)

The Princess Theater was located at 276 th $\mathrm{N}$ and opened on April 29, 1911. By 1912 it was run by Harry K. Spalding who kept it through 1915.

SAVOY THEATER (JAMES AMUSEMENT COMPANY)

The Savoy Theater was located at 1026 th St. $N$ and was being run by Edward S. Bair before the end of 1911 .

GLOBE THEATRE COMPANY

The Globe Theatre Company, which established the Globe Theater, shared family and business ties with the PAC, although the two companies were never affiliated on a business level. I. Leeser Cohen, D. Solis Cohen's brother, was treasurer/manager and its most active public figure. Alexander Bernstein, D. Solis Cohen's partner and Film 
Supply Company officer, served as secretary. It was reconstituted as the Portland Amusement Company in 1914 under the continued presidency of A. L. Levy. One result of reorganization was acquisition of two second-run theaters, the Casino and the American.

CASINO THEATER (GLOBE AMUSEMENT COMPANY)

The Casino Theater was located at 285 Burnside.

AMERICAN THEATER (GLOBE AMUSEMENT COMPANY)

The American Theater was at 1st and Main.

COLUMBIA THEATER

The Columbia cost one hundred thousand dollars and opened on June 19, 1913. The Columbia's architects were Camp and Dupuy, and it was built by the J. P. Taylor Co. on a fifty by one hundred foot lot. It was managed by $\mathrm{Mr}$. 0 . T. Bergner during Foster \& Kleiser's ownership. The street address was 106 th St.

When Foster \& Kleiser leased the Columbia they still maintained the Alhambra theater in seattle and the Valencia theater in San Francisco.

Jensen \& Von Herberg transferred Edward J. Myrick from Seattle to manage the Columbia. Myrick was originally a confectioner in the Midwest before getting into motion picture theater management in Arkansas and Montana. He 
worked for Jensen \& Von Herberg in Seattle from 1912-1915 at the Mission and Alhambra theaters. In July or August of 1915 he came to Portland.

SUNSET THEATER

Jennings and Son ran the theater as the Arcade from April 1 - 14, 1914, with Mr. J. E. Murphy as manager, before closing it for renovation. Four months later, after thirty thousand dollars worth of construction, the building reopened as the Sunset on July 31, 1914, with J. E. Murphy as manager.

John Jennings was a real estate agent who had lived in Portland for 33 years.

NATIONAL THEATER (NATIONAL AMUSEMENT COMPANY)

winstock announced the National Amusement Company's formation on March 11, 1914. It was capitalized at seventy five thousand dollars. Co-founders of the enterprise included John C. English, John Beall and Wilber Coman.

The National Theater was designed by Aaron H. Gould. The one hundred by one hundred foot lot was leased from the Farrell Investment Company in February 1914. Construction was delayed until a building permit was granted in June, and the theater was constructed by the Boyajohn-Arnold Company The National opened on October 29,1914 . John C. English owned J. C. English \& Co., a Portland 
lighting fixture firm. John Beall had run Beall \& Co.

Security Vault \& Metal Works in Portland since 1909. Wilber Coman had spent the decade before 1914 working as passenger and freight agent for the S. P. \& S and O. R. \& N., and his involvement with motion pictures, in a way, dated back to 1903 when he appeared with Edward Shields in Selig's filming in the Columbia Gorge.

ALLEN C. CHURCHILL

Allen C. Churchill had worked in real estate since 1909 in Churchill-Matthews \& Co. until 1914 when he became vice president of Northwestern Investment and Mortgage Company.

\section{STANFIELD ARNOLD}

Co-ownership of the Boyajohn-Arnold construction company, which built the National Theater, seems to have caused Stanfield Arnold's involvement.

A. L. STEVENS

A. L. Stevens seems never to have been based in Portland, and his business background is unknown.

JOHN P. WINTER

A lawyer in Portland since 1912, John P. Winter may be the J. P. Winter referred to in National's board. 
PAUL EMERSON NOBLE

Grombacher chose Paul Emerson Noble to replace Goodwin as the National's manager. Noble had several years experience in motion picture theater management beginning in Montana, where he even worked as piano accompanist to films. He came to Portland in 1913 as the local manager of the Alco-Alliance film distributorship, which was one of the sources of Metro, and he had undoubtedly had worked with Grombacher for at least two years if their work together had not begun earlier in Montana.

CHAPTER IV

MOTION PICTURE EXHIBITORS' LEAGUE

They met at Eiler's Hall on September 25, 1913 and elected their initial officers:

$\begin{array}{ll}\text { president } & \text { Melvin Winstock of Peoples } \\ \text { Amusement company } & \\ \text { vice president } & \text { J. A. Bradt of the Echo Theater } \\ \text { secretary } & \text { W. E. Stevens of the Woodlawn } \\ & \text { Theater } \\ \text { treasurer } & \text { G. T. Holtzclaw of the Cineograph } \\ & \text { Theater } \\ \text { sgt at arms } \quad \text { T. M. McGuire of the Bakeronian } & \text { Theater } \\ \text { executive board } \text { O. T. Bargner of the Columbia } \\ \text { Theater }\end{array}$


I. Leeser Cohen of the Globe Theater

Mr. Langerman of the New Grand Theater

H. C. Stevens of the Casino Theater J. A. Bradt of the Echo Theater judiciary committee H. C. Phillip of the Knob Hill Theater

R. Z. Duke of the Princess Theater E. T. Pittman of the Union Avenue Theater

A Motion Picture Exhibitors' League banquet was held December 23, 1913 at the Hotel Oregon presided over by Melvin Winstock and including Governor west and Mayor Albee. After its adoption as the Oregon chapter, the local exhibitors group chose new officers:

secretary

treasurer national

vice president I. Leeser Cohen of the Globe Theater 1915 members for the Oregon chapter were: president E. F. James of the Majestic Theater vice president Sol Baum of the Peoples Amusement Company

secretary W. E. Stevens of the Woodlawn Theater 
STAR THEATER FIRE

The star Theater fire occurred at about 8:45 p.m. on Monday, September 15. Milton McGuire "...was trimming a lamp, and a spark dropped into the film box, the film - a highly combustible material - instantly shot into flames...McGuire, the machine operator, was slightly burned about the hands in extinguishing the fire." The insured damage totaled less than five hundred dollars.11

\section{BAKERONIAN THEATER FIRE}

The Bakeronian Theater experienced a fire at 7:30 p.m. on January 8, 1911. "Operator W. J. Sparks was in the lamp room, running off a reel when it ignited and exploded with a blinding flash. Sparks escaped with singed hair and eyebrows. Extensive damage was done within the lamp room by the explosion, but it was fire-proofed and the blaze did not extend further." "The house was crowded with spectators. Attaches quieted the crowd. Several young women were overcome." 12

OH JOY THEATER FIRE SCARE

At 3 p.m. on January 15, 1911, a fire broke out in the basement of the O.L.C. Liquor store at 249 Morrison. The Oh Joy theater was over the liquor store's west basement and some smoke permeated the theater. The house was full of "mostly children."13 
NOB HILL THEATER FIRE

Two hundred people were in attendance when a fire occurred at the Nob Hill theater at 23 rd \& Kearney shortly before 9 p.m. on May 9, 1913.

DIME THEATER FIRE IN SOUTH BEND, WA.

A fire occurred at the Dime Theater in South Bend, WA. on July 4, 1914. The theater suffered three thousand dollars in damage. "Roy Green, operator of the moving picture machine, had his hands and arms badly burned."14

THEATER FIRE IN CENTERVILLE, WA.

Fire struck a moving picture theater in Centerville, WA., on July 19, 1914. The fire "started in a moving picture theater at Centerville, WA. tonight while a film was being shown, wiped out nearly half the business section of the town." "The spectators in the theater escaped uninjured, but the moving picture operator, Ray Pierce, was severely burned on his arm." Damage amounted to fifteen thousand dollars. ${ }^{15}$

MAJESTIC THEATER (JAMES AMUSEMENT COMPANY)

In August 1913 the Majestic theater received "...complete overhauling and redecoration of the house...", The Majestic underwent construction for its entrance to "be much more attractive, convenient and desirable."16 
STAR THEATER (PEOPLES AMUSEMENT COMPANY)

In November 1913, Star Theater "...nothing of artistic effort has been spared in the matter of decoration and furnishings." 17

PEOPLES THEATER (PEOPLES AMUSEMENT COMPANY)

The Peoples theater underwent renovation in December 1914 and "...kept in view the tastes of the women patrons..." including "...new carpets, draperies...."18

STAR THEATER LAWSUIT

William D. Allen sued the Star Theater for an incident which occurred on July 28,1915 . "He declares the usher grabbed him by the coat and forcibly prevented him from taking the desired seat." Through his lawyer, McCants Stewart, Allen sued for:

Mortification \& Chagrin

Flowers

Taxicab Hire

Theater Tickets

Violence of Head Usher

$$
\begin{array}{r}
1000.00 \\
.75 \\
10.00 \\
.10 \\
2500.00
\end{array}
$$

$$
3501.95^{19}
$$

BELIEF IN FILM'S DELETERIOUS INFLUENCE

A woman in Denver in 1910 saw a film in which a person 
was murdered in his sleep. She soon after killed her husband while he slept.

American Humane Association of San Francisco believed that censorship was the only remedy.

Fire Marshal of Albany, or saw films as an inspiration for pyromaniacs.

Lewis Sires, fifteen-year-old Native American, piled obstructions on railroad tracks in the salem area and then went up to the train pretending innocence as he warned them of the danger ahead. He said he saw the same thing done in a film, and the perpetrators were rewarded and hailed as heroes by the railroad.

A Los Angeles area teenager said movies inspired his car thievery.

Irvington PTA urged adoption of a children's night at the East Broadway theater to teach moral lessons.

Circuit Judge Gatens, citing widespread attendance of children at moving picture theaters late in the evening and the bad company that they might encounter at those hours, proposed an ordinance requiring children accompanied by parent to theaters after curfew.

Mrs. Newell of the Portland Board wanted the board to be able to review movie posters, saying they were often "vulgar, indecent or harmful to children."

A community meeting led by the Sunnyside Push Club resolved to oppose the planned erection of a motion picture 
theater at 39 th and Hawthorne. In his pleas and assurances the theater owner, Mr. Brant, pledged that he would not cater to children.

\section{JEFFRIES-JOHNSON FILM AND BUNGALOW THEATER}

Judge Kavanaugh issued a restraining order on December 31, 1910 prohibiting police from confiscating property of the fight film promoters but still allowed the possibility of promoters' and patrons' arrests based on a 1903 statute prohibiting film exploitation of a crime.

John F. Logan, representing the Bungalow, insisted that the film did not constitute a crime while City Attorney Leon held that depiction of what was a crime (boxing) was actionable by the 1903 statute. Jeffries-Johnson film promoters stated their determination to show the film that day at the Bungalow, despite police warnings. The film was not shown on January lst as promised, but the promoters were still determined to show it on the 2nd. Mayor simon, meanwhile, commented that the boxing films were immoral. A private press screening of the film was not held, as planned by the promoters, to show its innocent nature.

Reverend Benjamin Young and W. F. Reagor publicly supported the mayor and police position on the JeffriesJohnson film. 
WOLGAST-MORAN FIGHT FILM AND LYRIC THEATER

On complaint of John Bain of the Municipal Association Keating \& Flood were charged with a crime when they showed the Wolgast-Moran fight film at the Lyric on July 29, 1911. Based on the 1903 statute Keating \& Flood were convicted.

\section{FIGHT FILMS AT BIJOU THEATER}

Plans by the Bijou to show the Johnson-Flynn fight and the Pantages to show the Rivers-Wolgast fight were foiled by police chief slover who warned them that they would be subject to arrest based on the 1903 statute. The theater owners complained that on many occasions since January 1911 fight films had been shown in Portland without prosecution. The Interstate Commerce Act revision became effective July 31,1912 .

The Bijou planned to show the Johnson-Flynn fight film and felt that the law used to bar boxing films in Oregon was not legally relevant. Bijou manager O. F. Woody and Tacomabased distributor of the film, Meyer Cohen, forced Woody's arrest on charges of violating the statute to test its validity in court. To their dismay the newly instituted Interstate Commerce Act was applied instead of the 1903 statute. Since the fight took place in Las Vegas, Nevada, transportation of the film across Nevada state lines violated the federal law. Woody was convicted and fined one 
hundred dollars. Reverend Benjamin Young worked with the prosecution team in seeking means to convict Woody and uphold the ban on boxing films.

JOHNSON-BURNS FIGHT FILM IN 1914

A First Street movie theater was showing 1909's Johnson-Burns fight film to an avid crowd in 1914. The film was confiscated by police much to the vocal dismay of the audience. The Interstate Commerce Act justified the film's seizure.

ORIGIN OF PORTLAND CENSORSHIP BOARD

Gay Lombard introduced an ordinance calling for an unofficial advisory board but soon came to feel that it was an unwise move. When he spoke against his own proposition, Valentine Pritchard, a prominent member of Portland's Peoples Institute, spoke to the council in its favor.

Upon the board's inception Melvin winstock announced the support of Portland's exhibitors, promising cooperation. He also promised support for a board with legal powers if the advisory system proved unsatisfactory.

The board's initial delegates were representatives chosen by Portland women's clubs and charitable organizations:

Eleanor Colwell represented Associated Charities Valentine Pritchard represented the Peoples Institute 
Flora K. Lippitt represented the Council of Jewish Women

Mrs. W. M. Newill represented the Women's Club Millie Trumbull represented the Child Labor Commission

LOCAL EXHIBITORS AND THE PORTLAND CENSORSHIP BOARD

In January 1913 an open newsletter distributed by George Grombacher of the Independent Western Film Exchange to Northwest film renters in general spoke of the Portland board: "the persons appointed for such duties assume a great deal of authority and are rather abusive.'" Mrs. E. B. Colwell retorted angrily in defense of the board, while Melvin Winstock and H. C. Stevens responded diplomatically, assuring continued cooperation by Portland's exhibitors. ${ }^{20}$

In January 1914 Edwin James was intent upon showing the New York board-approved film 'Sapho' at the Majestic. Portland's board, however, rejected the film. James felt that since the board was only advisory its opinions were not binding and chose to ignore it. Mayor Albee met with James and secured his agreement to withdraw 'Sapho'. The next day an ordinance was passed appointing Portland's police chief as an official censor with the "power to seize any film which proves objectionable." The board itself remained advisory $\cdot^{21}$ 
DEVELOPMENT FROM ADVISORY TO LEGAL BOARD OF CENSORSHIP

A few instances illustrate where the appeal board proved an ally to theater managers. In February 1914, a decision overruled the board's (advisory) ban by allowing the Heilig to show 'Inside of The White Slave Traffic' with an age eighteen-and-over provision. In June 1914, the local board banned 'House of Bondage' from the Heilig, in contrast to the national board's approval, inspiring concern over these discrepancies. Early in March 1915, the board rejected the proposed exhibition of 'Kreutzer Sonata' at the Majestic as morally "'low and bad'". Although it had passed the national board the film was pulled by police from the theater during a performance. The matter went to the appeal board, led by Judge Stevenson, and 'Kreutzer Sonata' was approved. ${ }^{22}$

By May 1914, Mayor Albee was becoming upset with many instances of theater non-compliance with the board's opinions. He threatened "drastic legislation to curb the practice unless it is stopped." In June, he met with exchange and theater representatives over the same problem and received renewed promises of cooperation at the meeting although winstock said that the idea of legal censorship was "UnAmerican" . ${ }^{23}$

Albee was annoyed enough again by July to propose an law establishing a legal board based on San Francisco's censor ordinance. At the time, the Portland board had "power 
only to disprove and discard pictures of an indecent, immoral or obscene nature. This, it is said, has not been sufficient and has not been satisfactory either to the censors or the theater people." Portland's chapter of the Motion Picture Exhibitors' League said it wouldn't support the new ordinance if an appeal board was not provided. winstock said, "'I object seriously to the attempt to make the local public believe that Portland exhibitors are seeking to show immoral, obscene or indecent films" and he didn't feel "'that only a half a dozen people should have the absolute power over a great industry such as ours." 24 In response, Albee cited the 'Sapho' incident as an example of the failure of cooperation which forced him to give the police chief censorial powers. Albee justified his actions and opinions as "'necessary to protect the youth of the city in particular and the whole public in general." James, for his part, said that the mayor had called him and refused to permit him to show 'Sapho' despite its approval by the appeal board, stated that he didn't show offensive films because they didn't sell, and included several letters by prominent Portland citizens attesting to the Majestic Theater's quality. ${ }^{25}$

In late July, Albee proposed the new censor ordinance to the City Council which rejected it in August as "too sweeping." Albee tried to co-opt Winstock, who was speaking for the theater interests at the council meeting, by 
offering him a position on the new board if he would support the ordinance proposal as it stood. Winstock declined. ${ }^{26}$

In October, the board experienced internecine warfare, primarily over the retention by Albee of Mrs. A. C. Newill on the board even though she was no longer the choice of the Women's Club. Mrs. Trumbull and Mrs. Colwell were very upset with Newill's performance and felt she was not working toward the board's best interests. That same month, after having had his proposed ordinance rejected in August, Albee again received reassurances of cooperation from local exhibitors.

Albee was again fed up with less than total cooperation in February 1915 and reintroduced his ordinance for a censor board with legal powers to the adamant opposition of theater managers. Winstock said the ordinance proposal "'is not based on a clear public need or demand and is being put through because a few theaters have not played fair... no few people can be safely trusted to regulate and measure public taste." John Cordray noted that "'if the public demands the salacious in pictures, censorship would have, in time, to bow before it." Mary Anne Smith, film columnist for the oregonian, noted that "'the film in Portland is now at the mercy of the city council.'"27

Albee's ordinance passed on February 20, 1915, superceding ordinance 28375, and became effective on March 21. Mrs. Trumbull resigned from the board on March 10 th and 
was replaced by Mrs. H. L. Vorse. As the only salaried member, at fifty dollars per month, Mrs. Colwell was chosen as the new board's secretary. Mrs. A. C. Newill presided as chairman over a board consisting of Mrs. H. L. Vorse, Mrs. A. M. Gray, Mrs. Sol Hart, Sol Baum of the PAC, and W. S. Wessling of the Pathe Exchange. In June, Albee instructed Colwell to also censor films being shown at bars in town and looked into requiring them to obtain motion picture theater licenses.

The board's legal decisions after March 21 proved to be sometimes arbitrary and disruptive to downtown theater business. The film 'The Human Menace' had been passed by the local board but still suffered excisions when Navy Lt. R. R. Smith complained about images of drunken and womanizing sailors. Colwell had the scenes cut and the film's poster confiscated. Newill soon commented that posters should be regularly censored, too, because they "may be vulgar, indecent or harmful to children and others in any one of many ways." 28

In April, the Majestic's 'The Valley of The Missing', passed by the national board, was rejected and confiscated because it showed criminality. It was as a result of this action that James filed his suit to nullify the board.

The Sunset's 'Gussle Rivals Jonah' was barred in May. When it was shown anyway, manager J. E. Murphy and projectionist Milton McGuire were arrested. Colwell had 
determined that a comic resuscitation scene showing a stream of brine issuing from the victim's mouth was "revolting and disgusting.'" Since the film starred Frank "Fatty" Alexander, a Portland native, there were public requests that it be shown, which it was after the scene was excised. C. J. Kerr, of the local Mutual Exchange, was fined twenty dollars for "causing to be exhibited a film which the motion picture censors would not approve without certain excisions...." Murphy and McGuire were acquitted on the technicality that colwell did not give them official notice of the board's disapproval, although she grumbled that they still knew its exhibition was forbidden. ${ }^{29}$

In July, George M. Harris, manager of the Burnside Theater at 5th \& Burnside, was arrested for showing the condemned film 'Sontag And Evans,' which depicted the adventures of two $1890 \mathrm{~s}$ train robbers.

'Kreutzer Sonata,' which had been passed on appeal early in March, was rejected by Colwell in August as immoral and banned.

The Columbia's presentation of 'Stolen Magic' was confiscated from the theater during a performance in December due to scenes "which would frighten children and were not pleasant for delicate women." The film was allowed to play after necessary excisions. ${ }^{30}$

Judge Davis ruled against Edwin James on June 7, 1915. 
RESISTANCE TO THE STRENGTHENED CENSORSHIP BOARD

Organized opposition to the board began in the summer of 1915. In August the board's rejection of the Majestic's 'Cup of Chance' led to a meeting of Portland theater owners and film distributors, who agreed that Colwell was "arbitrary and capricious...they suffer unwarranted heavy financial losses as a result." Edwin James said, "'It is her absolutely unreasonable actions that have caused us to raise an organized protest...It's absolutely ridiculous that one woman should set herself up as the dictator of the business in the city...she's always indignant, always does things in an angry mood...every criminal has a right to appeal, why haven't we?'" Tension then erupted in the board itself resulting in a schism of Newell, Vorse, Gray and Colwell against Wessling and Baum. G. A. Metzger of Film Supply Co. of Oregon wrote of "unjust interference" by the board and made a general call for restoration of the appeal board. ${ }^{31}$ Prominent men - P. E. Sullivan of Portland Press Club, F. Grandberg of Portland Railway Light \& Power, Circuit Judge W. W. Gatens, Judge Cleeton, Deputy District Attorney Ryan, County Clerk Mr. Coffey, Chamber of Commerce president C. C. Colt, and Philip s. Bates - noted themselves in favor of the appeal board's restoration or abolition of the censor board altogether. Colwell spoke to Westminster Presbyterians and at a Civic League luncheon to encourage support for the board. In November 1915 D. S. Cohen, for the local theater 
owners, asked the city council to amend the censorship ordinance and restore the appeal board but was rejected. In December 1915 the Portland Protective Association was reincorporated "to include all theatrical and moving picture people of Portland" and favored appeal board restoration. Said an unnamed local exhibitor about the board: "They sit down to view a film apparently assuming the viewpoint of the most depraved spectator-looking for something low and suggestive. " 32 
APPENDIX QUOTE SOURCES

1. "Among Our Neighbors", Oregon Journal (November 14, 1939), sec. $1 \mathrm{pg} .10$.

2. "The Vitascope At Cordray's", Oregonian (December 8, 1896), sec. 1 pg. 10., "The Viascope(sic) At Cordray's". Evening Telegram (December 8, 1896), sec. 1 pg. 6 .

3. "Amusements", Oregonian (December 14, 1896), sec. $1 \mathrm{pg} .5$.

4. "The Viascope(sic) At Cordray's".

5. Ibid., "The Vitascope At Cordray's", "Amusements" .

6. "New Pictures In The Vitascope", Oregonian (December 13, 1896), sec. 1 pg. 13.

7. "The Electrograph", Oregonian (August 7, 1897), sec. 1 pg. 12 .

8. "Empire Theater", Oregon Journal (October 30, 1903), sec. 1 pg. 7., "At The Empire", Oregon Journal (October 26, 1903), sec. 1 pg. 5 .

9. "The Lyric", Oregonian (July 24, 1904), sec. 1 pg. 18 .

10. "Police May Close Orpheum Saloon", oregon Journal (July 29, 1904), sec. 1 pg. 2 . 
11. "Theater Hands Stop Fire", Oregonian (September 16, 1913), sec. 1 pg. 16 .

12. "Film Burns; Women Faint", Oreqonian (January 9, 1911), sec. 1 pg. 7 .

13. "Blaze Most Stubborn", Oreqonian (January 16, 1911), sec. 1 pg. 7 .

14. "Theater Burns On Fourth", Oregonian (July 6, 1914 ), sec. $1 \mathrm{pg} .5$.

15. "Town Nearly Goes In Theater Fire", Oregonian (July 20, 1914), sec. 1 pg. 1 .

16. "Theater To Be Repaired", Oregonian (August 27, 1913), sec. 1 pg. 9., "Majestic To Be Changed", Oregonian (May 21, 1914), sec. 1 pg. 11 .

17. "Theater To Reopen", Oregonian (November 26, 1913), sec. 1 pg 12 .

18. "Theater Is Improved", Oregonian (January 5, 1915), sec. 1 pg. 5 .

19. "Theater Sued By Negro", Oregonian (September $17,1915)$, sec. 1 pg. 9 .

20. "Film Censors Are Stirred By Charge", Oregonian (January 30, 1913), sec. 1 pg. 11 .

21. "Censors Want Powers", Oregonian (July 9 1914 ), sec. 1 pg. 9 .

22. "Tolstoi Film Is Barred By Censor", oregonian (March 8, 1915), sec. 1 pg. 8 . 
23. "Mayor's Eye On Movies", oregonian (May 23, 1914 ), sec. 1 pg. 11., "Censorship Board Bowed To", Oregonian (June 6, 1914), sec. 1 pg. 11 .

24. "Censors Want Powers", Oregonian (July 9, 1914), sec. 1 pg. 7., "Movie Men Object", Oregonian (July 13, 1914), sec. 1 pg. 7 .

25. Ibid.

26. "Hearing On Movie Censorship Fails", Oregonian (August 7, 1914), sec. 1 pg. 12 .

27. "Movie Men Protest", Oregonian (February 8, 1915), sec 1 pg. 11., "At The Photoplay Theaters", Oregonian (February 14, 1915), sec. $4 \mathrm{pg} .4$.

28. "Poster Censoring Urged", Oregonian (April 9, 1915), sec. 1 pg. 18 .

29. "Movie Men Face Trial", Oregonian (May 23, 1915), sec. 1 pg. 19.

30. "Film, Seized, Is Released Again", Oregonian (December 19, 1915), sec. 1 pg. 1 .

31. "Movie Censors Hit", Oregonian (August 11, 1915), sec. 1 pg. 9., "Censor Called Unfair", Oreqonian (August 6, 1915), sec. 1 pg. 4., "Movie Men Roused By Woman Censor", Oregonian (August 7, 1915), sec. 1 pg. 4. 32. "Moving Picture News", Oregonian (December 15, 1915), sec. 1 pg. 6., "Moving Picture News", Oregonian (December 21, 1915), sec. 1 pg. 8 . 